\title{
Financing Sustainable Forest Management
}

Report of the International Workshop of Experts, 22-25 January 2001, Oslo, Norway

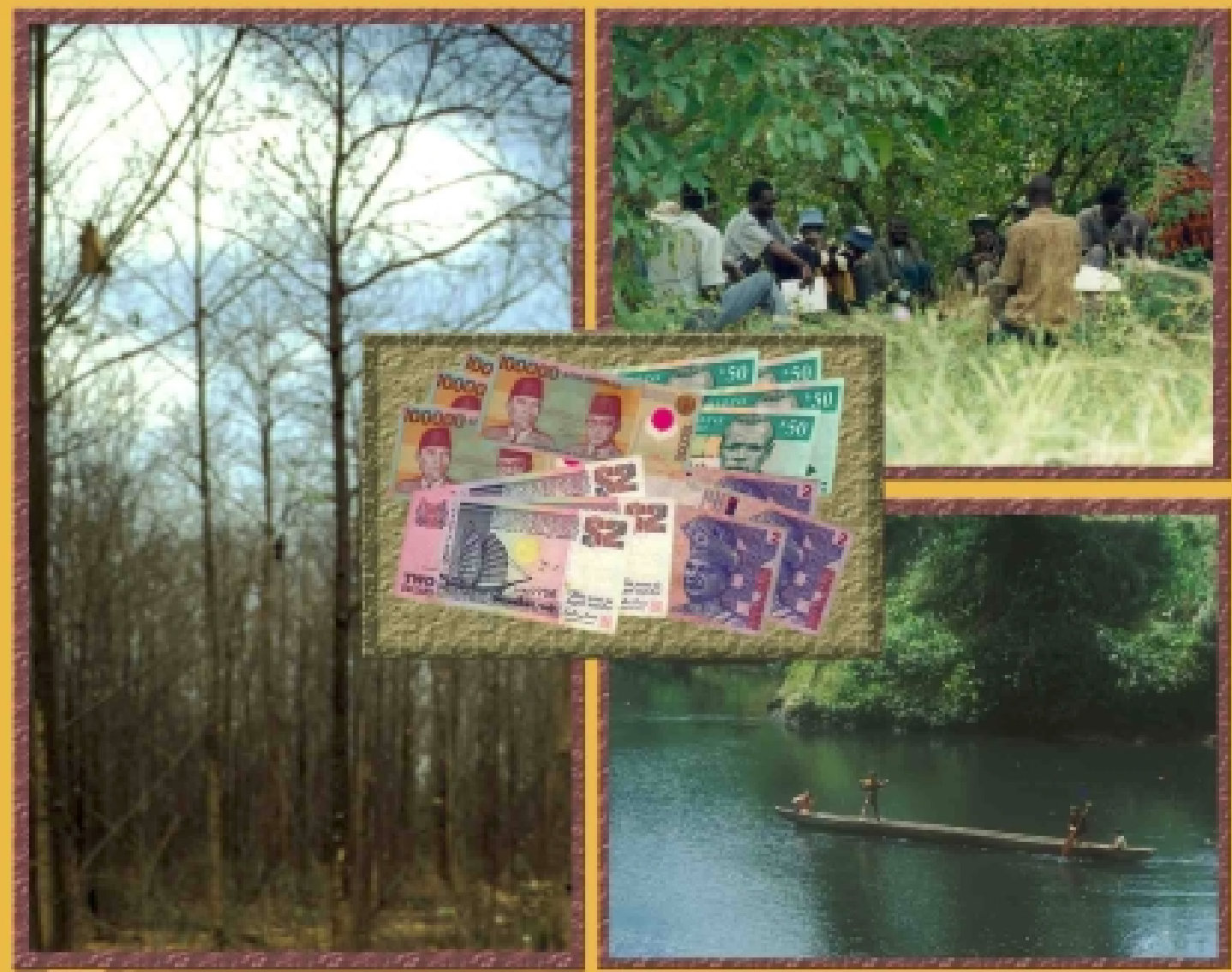

A Government-led initiative in support of the work of the United Nations Forum on Forests

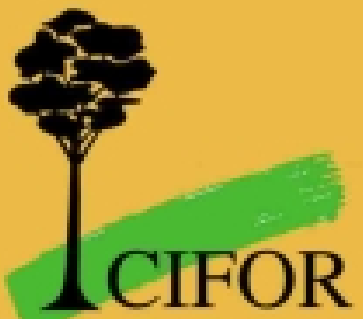




\section{Financing Sustainable Forest Management}

Report of the International Workshop of Experts 22-25 January 2001, Oslo, Norway

A Government-led initiative in support of the work of the United Nations Forum on Forests 
(C) 2001 by Center for International Forestry Research

Documents can be copied and quoted freely provided acknowledgement is made of the authors and of CIFOR. Published in May 2001

Printed by SMT Grafika Desa Putera, Indonesia

\section{ISBN 979-8764-68-4}

Chipeta, M.E. and Joshi, M. (Editors). 2001. Financing sustainable forest management. Report of the International Workshop of Experts, 22-25 January 2001, Oslo, Norway. Center for International Forestry Research, Bogor, Indonesia. 109p

\section{Sponsored by:}

Brazil, Denmark, Malaysia, Norway, South Africa and the United Kingdom

\section{Organised and published by}

Center for International Forestry Research

Bogor, Indonesia

P.O. Box 6596 JKPWB, Jakarta 10065, Indonesia

Tel.: +62 (251) 622622; Fax: +62 (251) 622100

E-mail: cifor@cgiar.org

Web site: http://www.cifor.cgiar.org 


\section{A Note to the Reader}

A set of four reports has been prepared to communicate the outcome of the "Oslo Workshop" to a range of audiences:

Highlights: A "Highlights" document was produced at the workshop itself that summarised the main messages from the meeting.

Formal report: With the intention of providing an input into the work of the United Nations Forum on Forests, an edited version of the "Highlights" was formatted as a formal report and officially transmitted to the Secretary General of the United Nations by the six co-sponsoring governments of the Oslo Workshop.

Proceedings: The "Highlights," accompanied by the full set of papers for the workshop have been released as Proceedings but only as a CD-ROM and in electronic form on the CIFOR Website.

Main report: The present publication is the main report. It combines an edited version of the "Highlights" with complementary synthesis of main messages from the rich discussion, as well as summaries of the papers prepared for the Workshop. This main report is available in hard copy as well as on the CIFOR Website.

Private sector report: The last output is a publication to communicate private sector views regarding its interest in Sustainable Forest Management, its perception of constraints, and suggestions for changes to facilitate its greater engagement in SFM investment.

The present publication is the main report. It has been deliberately designed for reading not only by officials and professionals but also by the general public. For this reason we 
requested a professional text editor to help clarify the language and we took two other decisions to achieve wider readability: a) while largely retaining the exact wording that was developed at the Oslo Workshop for the "Highlights", we have encouraged light editing for greater clarity but without changing the meaning; and b) we have avoided mid-sentence cross-referencing to authors, which interrupts reading flow. To compensate, we have included summaries of the papers where the key messages can be read in context.

This document has been assembled and edited by Mafa E. Chipeta and Mahendra Joshi working in their individual capacities. Condensing papers, conveying the essence of workshop discussions, and elaborating on wording developed at the conclusion of the Workshop involved considerable interpretation. In doing the synthesis, the co-editors have sought, above all else, to convey the spirit of discussions and the intent and emphasis desired by the authors and presenters; the original authors were requested to study the summaries of their papers before publication.

Should there be cases where the efforts of the editors have not succeeded in fully conveying the main message and spirit of the originals, responsibility rests with the editors as individuals and not with their respective employers, the Oslo Workshop Steering committee, the original contributing authors, or the co-sponsoring governments.

Mafa E. Chipeta

Center for International Forestry Research

Bogor, Indonesia

18 May 2001
Mahendra Joshi

Secretariat of the UN Forum on Forests

United Nations, New York 


\section{Table of Contents}

A Note to the Reader iii

Members of the Steering Committee for the Oslo Workshop ix

List of Acronyms and Abbreviations $\quad x$

Acknowledgements $\quad$ xi

\section{Part I: Report of the Workshop}

$\begin{array}{ll}\text { Chapter 1: Highlights of the Workshop } & 1\end{array}$

Background 1

Highlights 3

An Enabling Environment for Investment in Sustainable

Forest Management 3

Private-Sector Financing of Sustainable Forest Management 4

Investment Promotion Entity (IPE) as a Potential Means

of Promoting SFM Financing $\quad 6$

Other Means of Increasing Financial Resources from All Sources, $\begin{array}{ll}\text { Including the Global Forest Fund } & 7\end{array}$

$\begin{array}{ll}\text { Additional Points } & 10\end{array}$

Matters Proposed for Particular Attention by the UNFF 11

$\begin{array}{ll}\text { Chapter 2: Workshop Discussions and Key Messages } & 13\end{array}$

$\begin{array}{ll}\text { Background: The Road to Oslo } & 13\end{array}$

$\begin{array}{ll}\text { Earth Summit Origins } & 13\end{array}$

The Intergovernmental Panel on Forests and the Intergovernmental

Forum on Forests

$\begin{array}{ll}\text { Foundation for the Oslo Workshop } & 15\end{array}$ 
Selected Overarching Issues in the Funding of SFM 16

The Importance of an Enabling Environment for SFM Investment 22

Improving Private-Sector Engagement and Public-Private

Partnerships in Forest Sector Investment $\quad 24$

$\begin{array}{ll}\text { Investment Promotion Entity (IPE) } & 28\end{array}$

Global Forest Fund (GFF) and Related Mechanisms 29

Other Means of Increasing Financial Resources from All Sources 31

\section{Part II: Summaries of Papers for the Workshop}

\section{An Enabling Environment for Investment} in Sustainable Forest Management*

Changing Perceptions on Technical Assistance in Support of Sustainable Forest Management

Lennart Ljungman and C.T.S. Nair

Towards an International Enabling Environment for Investment in Sustainable Forest Management Lai Har Chan

Private-Sector Financing of Sustainable Forest Management

Investing in the Future: The Private Sector and Sustainable

Forest Management [lead paper]

Hans Gregersen and Arnoldo Contreras-Hermosilla

Private-Sector Investment in Sustainable Forest Management

in Humid Tropical Africa

Jean Jacques Landrot and Steven Speed

The Private Sector and Sustainable Forest Management -

Southeast Asian Perspective

Barney S.T. Chan

The Private Sector and Sustainable Forest Management -

South America Perspective

Ivan Tomaselli

The Private Sector and Sustainable Forest Management A Private Perspective from South America's Southern Cone Fernando Raga Castellanos

\footnotetext{
*Enabling Environment concerns featured in almost all papers, especially those prepared by the private sector, in the national papers, and presentations of the multilateral development banks and funds; the grouping here is largely for convenience of presentation.
} 
Investing in Sustainable Forestry

Peter Mertz

Mechanisms to Encourage Private-Capital Investment

in the Environmental Services of Forests

David Brand

Certification and Sustainable Forest Management

M.K. Muthoo

The Private Sector and Sustainable Forest Management -

Perspective from Southern Africa

Mike Goldbatt

Investment Promotion Entity (IPE) as a Potential Means for Promoting Sustainable Forest Management

Feasibility and Operationalisation of an Investment Promotion Entity (IPE) for Sustainable Forest Management - Highlights from the Main Papers

Mafa E. Chipeta and Mahendra Joshi

Assessing the Feasibility and Operationalisation of an Investment Promotion Entity (IPE) for Sustainable Forest Management [lead paper]

Pedro Moura-Costa, Lionel Fretz and Gerald Kohn

Assessing the Feasibility and Operationalisation of an Investment

Promotion Entity (IPE) for Sustainable Forest Management:

Demand and Supply Aspects

Jyrki Salmi, Tapani Oksanen and Markku Simula

Global Forest Fund and Related Mechanisms

The Global Forest Fund - From Rio to IFF4:

What Issues Remain? [sole paper]

Mahendra Joshi and Mafa E. Chipeta

Global Forest Funding - Exploring Consortium Financing

of Sustainable Forest Management [lead paper]

Barin Ganguli

Consortium Funding for Sustainable Forest Management:

African Perspectives and Priorities

Frank S. Kufakwandi

Other Means of Increasing Financial Resources from All Sources

International Funding Mechanisms

Financing Sustainable Forest Management:

Doing More With (Probably) Less [lead paper]

Jim Douglas 
Forest Financing in Latin America and the Caribbean:

A View from the Inter-American Development Bank

Kari Keipi

The Global Environment Facility: Experiences and Trends Lessons for Sustainable Forest Management

Kanta Kumari

Experiences of and Lessons in Sustainable Forest

Management Financing

Per Rydén and Simon Quatrini

National Funding Mechanisms

An Overview of National Forest Funds: Current Approaches and

Future Opportunities, [lead paper]

Kenneth L. Rosenbaum and Jonathan M. Lindsay

Financing Integrated Sustainable Forest and Protected Areas

Management in Indonesia: Alternative Mechanisms

to Finance Participatory Forest and Protected Areas Management

Herman Haeruman Js.

Financing Sustainable Forest Management in Norway

Knut Øistad

Financing Sustainable Forest Management in Russia and

the Commonwealth of Independent State Countries:

Alternative Mechanisms to Finance Participatory Forest

and Protected Areas Management

Anatoly Petrov

Experiences and Future Directions of Forestry Funding in Vietnam

Nguyen Xuan Nguyen

\section{Part III: Annexes}

Annex 1: Statements at Ceremonial Events

Annex 2: Workshop Agenda

Annex 3: List of Documents

Annex 4: List of Participants 


\title{
Members of the Steering Committee for the Oslo Workshop
}

\author{
BRAZIL: $\quad$ Everton Vargas \\ Minister \\ Head of the Division for the Environment \\ Ministry of External Relations \\ Brasilia \\ DENMARK: \\ Thure Christiansen \\ Head of Section \\ Secretariat of Environment and \\ Sustainable Development \\ Copenhagen \\ MALAYSIA: Lai Har Chan \\ Undersecretary of the Forest Division \\ Ministry of Primary Industries \\ Kuala Lumpur \\ NORWAY: $\quad$ Knut Øistad \\ Deputy Director, \\ Royal Ministry of Agriculture \\ Forestry Department \\ Oslo \\ SOUTH AFRICA: $\quad$ Lael Bethlehem \\ Chief Director: Forestry \\ Department of Water Affairs \& Forestry \\ Pretoria \\ UNITED KINGDOM: Richard Dewdney \\ Department for International Development \\ London \\ CHAIRMAN: \\ Mafa E. Chipeta \\ Deputy Director General \\ Center for International Forestry Research \\ Bogor, Indonesia \\ SECRETARY: Mahendra Joshi \\ Forestry Advisor \\ UNFF Secretariat \\ New York, USA
}




\section{List of Acronyms and Abreviations}

\begin{tabular}{|c|c|}
\hline AfDB & African Development Bank \\
\hline CBD & Convention on Biological Diversity \\
\hline CGIAR & Consultative Group on International Agricultural Research \\
\hline CIFOR & Center for International Forestry Research \\
\hline CEIT & $\begin{array}{l}\text { Countries with Economies in Transition } \\
\text { (often called Countries in Transition) }\end{array}$ \\
\hline $\mathrm{COP}$ & Conference of the Parties \\
\hline ECOSOC & United Nations Economic and Social Council \\
\hline FAO & Food and Agriculture Organisation of the United Nations \\
\hline FSC & Forest Stewardship Council \\
\hline GEF & Global Environment Facility \\
\hline GM-UNCCD & $\begin{array}{l}\text { Global Mechanism of the U.N. Convention } \\
\text { to Combat Desertification }\end{array}$ \\
\hline IDB & Inter-American Development Bank \\
\hline IPF & Intergovernmental Panel on Forests \\
\hline IFAD & International Fund for Agricultural Development \\
\hline IFF & Intergovernmental Forum on Forests \\
\hline ITTO & International Tropical Timber Organisation \\
\hline PROFOR & Programme on Forests (of UNDP) \\
\hline UNCED & $\begin{array}{l}\text { United Nations Conference on Environment and Development } \\
\text { (The Earth Summit) }\end{array}$ \\
\hline UNDP & United Nations Development Programme \\
\hline UNFF & United Nations Forum on Forests \\
\hline UNFCCC & United Nations Framework Convention on Climate Change \\
\hline WB & World Bank \\
\hline
\end{tabular}




\section{Acknowledgements}

The Steering Committee of the International Workshop of Experts on Financing Sustainable Forest Management ("the Oslo Workshop") was composed of representatives of the Governments of Brazil (Everton Vargas), Denmark (Thure Chritiansen), Malaysia (Lai Har Chan), Norway (Knut Øistad), South Africa (Lael Bethlehem) and the United Kingdom (Richard Dewdney). The Secretary was Mahendra Joshi of the U.N. Forum on Forests Secretariat while I, on behalf of CIFOR, was privileged to serve as Chairman. These words, from the Committee, are to convey thanks for the many contributions to conceptualising, preparing and carrying out the Oslo Workshop.

The six co-sponsoring governments wished to hold the Oslo Workshop in order to support further international dialogue on critical issues related to the financing of sustainable forest management. We want to thank these governments, and especially the Royal Norwegian Ministries of Agriculture and Forestry and of International Development and the Department for International Development of the United Kingdom (DfID,) for providing funds to make the workshop a reality.

We are indebted to Bjarne Håkon Hanssen, the Norwegian Minister of Agriculture and Forestry, for giving the opening keynote speech, and to Anne Kristin Sydnes, the Norwegian Minister of International Development, who hosted an event to welcome the participants. We also thank Oluf Aalde, Director of the Norwegian Department of Forestry, for chairing the sessions and providing steady guidance throughout the workshop. We would like to acknowledge with gratitude the Norwegian Forestry Society's logistical support and, in particular, the major contribution made by Tore Molteberg.

We thank all the authors who prepared the excellent, in-depth and well researched papers that made the workshop highly focussed and effective, as well as the expert participants who brought their insight to the workshop and contributed to the lively discussions and significant results. In this respect, we would also like to acknowledge the contributions of several international organisations, including the Food and Agriculture Organisation (FAO), the World Bank, the U.N. Development Programme (UNDP), the Global 
Environment Facility (GEF), the Global Mechanism of the Convention on Combating Desertification (UNCCD) and the Forest Stewardship Council (FSC), for contributing papers and other support.

The idea of the Oslo Workshop reflects the foresight of Ilkka Ristimaki, Co-chairman of the International Forum on Forests (IFF), who, along with Everton Vargas and Knut Øistad, saw the need for it during the fourth and final session of the IFF in early 2000. Our special thanks go to Jagmohan Maini, Co-ordinator and Head of the UNFF Secretariat, who spearheaded the effort for the proposed workshop and consulted with the cosponsoring and co-funding governments.

We would also like to thank Richard Scothorne for his efficient facilitation and Ralph Schmidt for his opening speech that set the context for the meeting. For their daily review of the workshop to help guide progress and their assistance to the workshop team, we thank David Brooks, Frank Kufakwandi and Markku Simula. Finally, many members of the CIFOR staff provided suggestions, logistical support and help in preparing the workshop papers. Thanks for a job well done go especially to Ketty Kustiyawati, for considerable responsibility in helping to organise the workshop, and to Lucya Yamin for her assistance and Gideon Suharyanto for his production of related publications.

\author{
Mafa E. Chipeta \\ (Deputy Director General, CIFOR, Indonesia) \\ Chairman, Oslo Workshop Steering Committee
}




\author{
Part I: \\ Report of \\ the Workshop
}

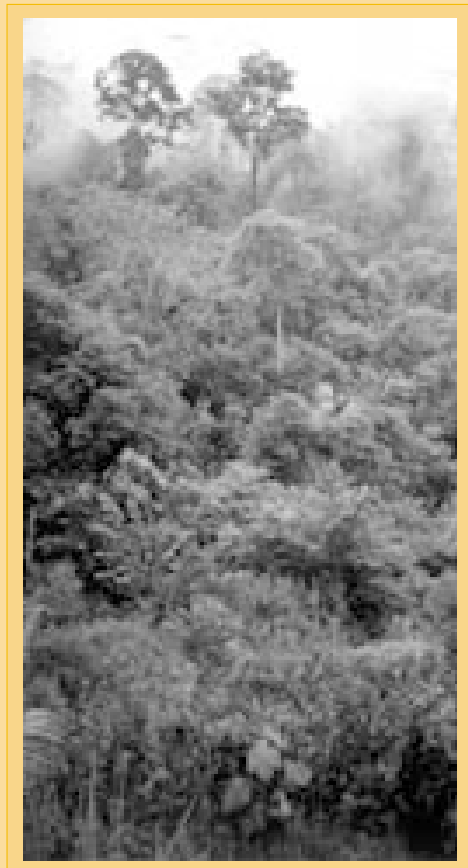




\section{Chapter 1}

\section{Highlights \\ of the Workshop}

\section{Background}

This publication is the main report of the International Workshop of Experts on Financing Sustainable Forest Management that was held 22-25 January 2001 in Oslo, Norway. It summarises the outcome of the workshop and is not its full Proceedings; the Proceedings are being issued separately and are available on the CIFOR Web site and on a CD-ROM disc. ${ }^{1}$

This report has three parts. Part I contains the main report, which comprises Chapter 1 an edited version of the highlights that were issued at the end of the workshop. These are not meant to be official text but an overview of matters that were discussed and mutually understood by the participants, lightly edited for greater clarity. Chapter 2 describes the main discussions and messages at the workshop; it also includes a brief history of international dialogue on financing sustainable forest management (SFM) since the 1992 Earth Summit in Rio de Janeiro and how it led to the Oslo Workshop. The last part of Chapter 2 is a list of issues derived subsequent to the workshop by the Steering Committee from the Highlights and proposed to the United Nations Forum on Forests (UNFF) for possible particular attention. Part II provides summaries of the papers prepared for the workshop. Part III, the annexes, contains the speeches and agenda of the workshop, a list of relevant documents and the list of participants. 


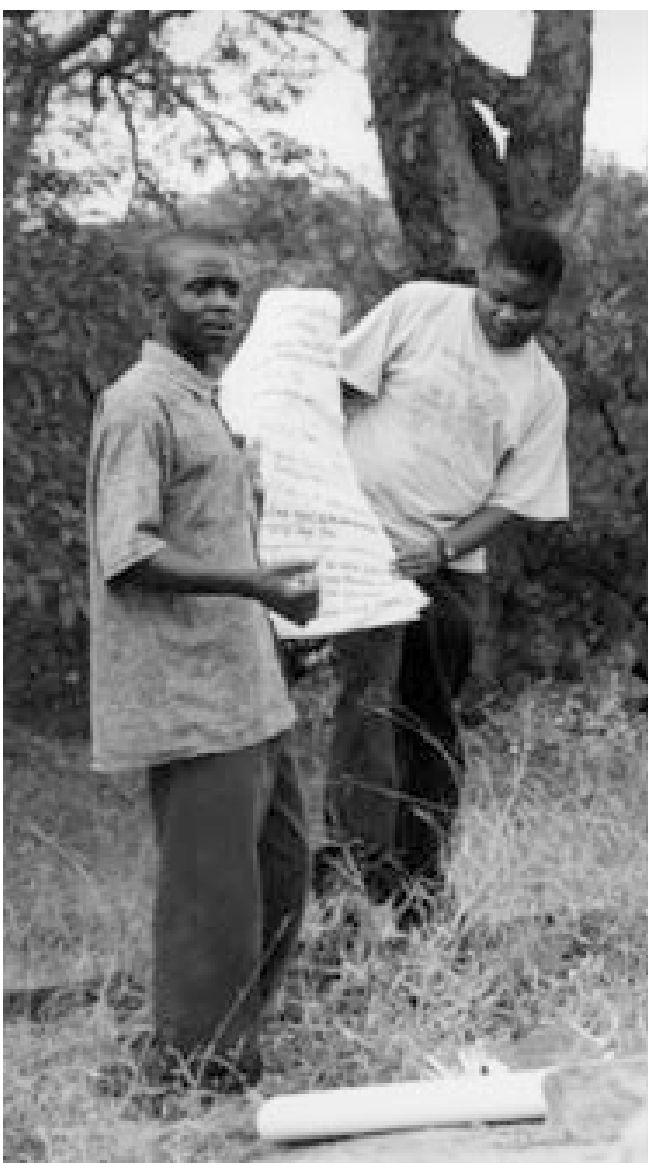

The Oslo Workshop was a government-led initiative in support of international policy deliberations under the United Nations, which started in earnest under the Intergovernmental Panel on Forests (IPF) and the Intergovernmental Forum on Forests (IFF) and now continue under its United Nations Forum on Forests (UNFF). The workshop was co-sponsored by Brazil, Denmark, Malaysia, Norway, the Republic of South Africa and the United Kingdom. It was co-funded by the Governments of Norway and the United Kingdom and organised by the Indonesia-based Center for International Forestry Research (CIFOR). The workshop was a follow-up to the Workshop on Financing of Sustainable Forest Management held in Croydon, U.K., in October 1999, which, in turn, had built upon the 1996 Workshop on Financial Mechanisms and Sources of Finance for Sustainable Forestry, held in Pretoria, South Africa.

Like the two related workshops it followed, the meeting in Oslo was organised to provide support to the U.N.'s post-Earth Summit international dialogue on forests by advancing discussions on the financing of sustainable forest management. In particular, the Oslo Workshop focussed on three topics: the feasibility of a proposed mechanism known as Investment Promotion Entity (IPE); private-sector financing of SFM; and other means of increasing financial resources from all sources, including the proposed Global Forest Fund.

The participants at the Oslo Workshop were 70 experts from 40 countries (developing countries, countries in transition, and developed countries) who brought a wide range of professional experience in government, the private sector, non-governmental organisations, financing institutions, international organisations, and academia. The outcome presented in this chapter as "Highlights" is not negotiated text but a summary of the broad understanding shared by the participants at the end of the workshop, when the original Highlights were presented and discussed. 


\section{Highlights}

\section{An Enabling Environment for Investment in Sustainable Forest Management}

The workshop participants recognised that lack of funding is often not the sole constraint to investment in sustainable forest management in developing countries and countries in transition; also important is the lack of enabling conditions. At the national level, a key factor is low commitment and priority given to the forest sector by beneficiary countries and their donor partners. This situation is often the result of a failure to make a convincing case for the socio-economic importance of the forest sector and its potentially significant contribution to development. Consequently, opportunities for funding are often missed because decision-makers are not aware that forests can help address priority concerns that merit preferential allocations, such as poverty reduction and sustainable development.

Funding the forest sector also requires an enabling environment at the international level. In general, the current situation is not positive. A continuing decline in commodity prices at the international level has prevented the forest sector, even in forest-rich developing countries, from yielding adequate financial surpluses that could be reinvested into SFM. Major international markets for forest products are price sensitive and tend to favour low-priced forest products, which often come from non-sustainable harvesting. This trend undermines the market share of responsible suppliers of forest products, which have to bear the full costs of sustainable practices yet often receive no price premium for their efforts. Therefore, promoting remunerative trade and fair prices is potentially important in making SFM investment possible.

Other important factors that constrain SFM investment are insecure tenure, policy and market failures, high levels of actual and perceived risk related to factors outside the forest sector's control, a lack of suitable credit options adapted to particular attributes of the sector, and weak and unstable regulatory

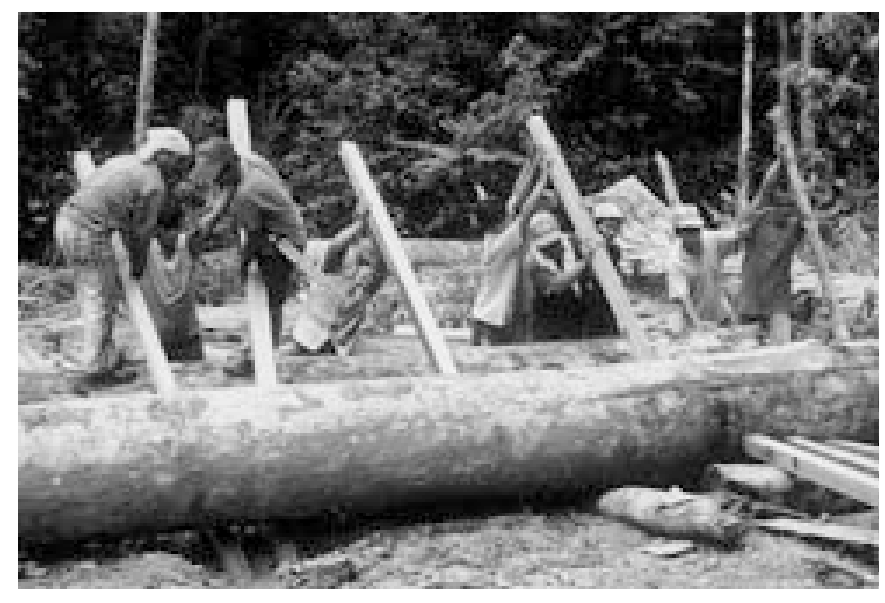


environments that encourage, rather than discourage, unsustainable or illegal practices. Similarly, factors that raise operational costs or reduce returns, such as overregulation, poor infrastructure and undeveloped markets, are disincentives for private investment. The additional costs involved in seeking to achieve SFM at a micro-scale (that is, seeking all benefits of SFM from each individual forest stand) compared with at the landscape level also discourages investment, especially by smallholders.

Because situations vary, individual developing countries and countries in transition must find solutions that are best suited to their own conditions as they seek to create an environment conducive to investment in SFM. Making SFM more profitable and less risky through policy interventions would increase the self-financing prospects of the sector and help mobilise new private investment. Nonetheless, many countries still have a need for external public funding through official development assistance (ODA) to support capacity building, the development of appropriate legal frameworks, and the creation of social and economic conditions conducive to investing in SFM.

\section{Private-Sector Financing of Sustainable Forest Management}

Sustainable forest management offers opportunities for economic gain alongside ecological and social benefits. To achieve this, greater investment is needed not only by the private sector (ranging from small farmers and communities to large international corporations) but also by the public sector, including through official development assistance.

Private investors seem to prefer investing in industrial plantations rather than in natural forests; accordingly, large companies have directed substantial flows of private capital to industrial plantations. Although this has occurred mainly in developed countries, the trend is spreading to include a growing number of developing countries where conditions are attractive for private capital. Given their more predictable levels of output

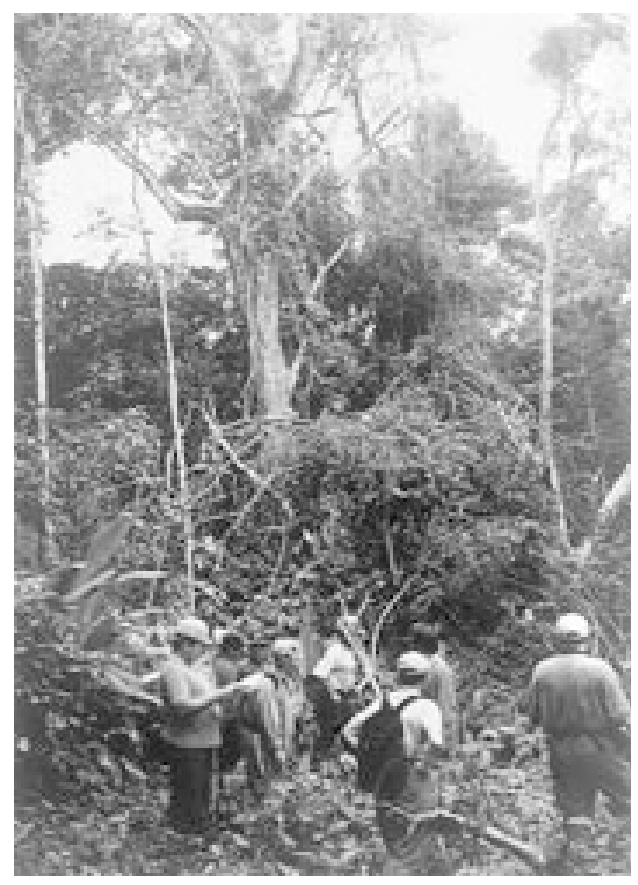


and their relatively short rotations, industrial plantations carry a lower level of perceived risk for investors than natural forests. Thus, public-sector incentives for this market segment appear to be less needed. In comparison, promoting sustainable management of natural forests and plantation development by smallholder will continue to require public support and incentives.

Major factors that influence private-sector decisions about forest-related investments include levels of returns, risks and transaction costs. Sufficient returns are a prerequisite; thus, any factors that increase costs represent another burden for the private sector and deter investment. Evidence indicates that small investors, in particular, find it difficult to meet the additional costs often associated with

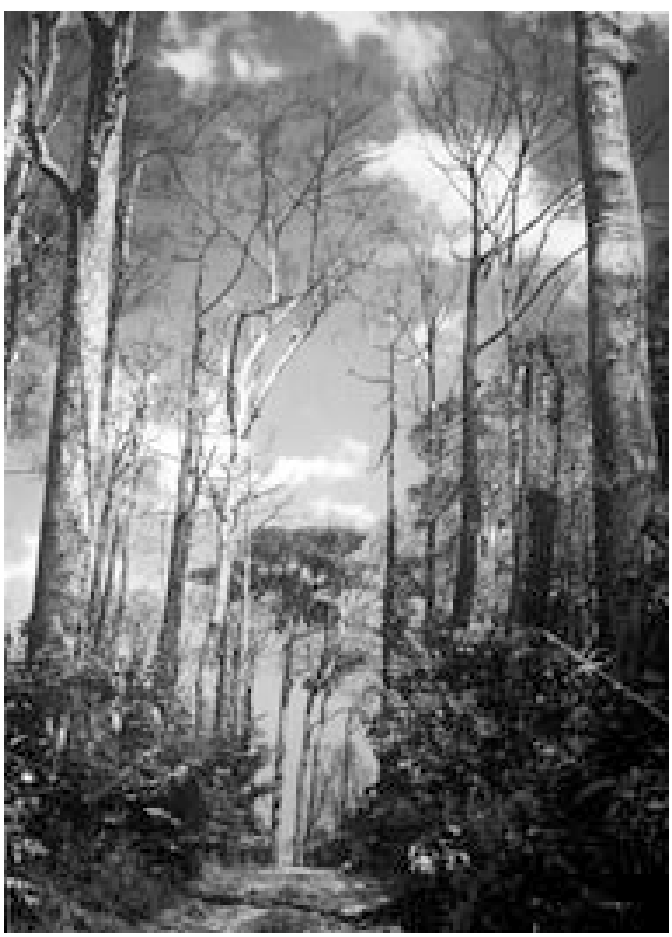
sustainable forest management. Weighing returns against risks, private investors generally demand much higher returns (typically 15 to 30 percent) from developing countries where conditions are such that risks may be seen as very high. Given this situation, risk mitigation - much of it in regard to factors outside the forest sector's control, could significantly help to promote investment in SFM. Reducing transaction costs is also important, especially to attract small investors.

Private-sector investors appear more reluctant to invest in SFM in natural forests because they see it as having high investment costs, being technically complex and offering only modest returns compared with alternative investment opportunities. Besides having significant risks and uncertainties, it is also associated with contentious environmental and social issues.

Ways to promote private-sector interest in SFM, including increased attention to natural forests, should be sought and promoted. Because forests provide considerable public benefits for society, there is often a need and justification for domestic and international public funding of natural forest management. ${ }^{2}$ In this way, the public-sector support would contribute to creating enabling conditions to leverage complementary private capital investment in SFM. Thus the complementary interests and roles of official and private capital offer many opportunities for public-private partnerships for SFM investments. 
At the same time, there is growing interest in investment and possible new opportunities for funding forest activities related to carbon sequestration and climate change mitigation, for which the international community continues to seek formal agreements.

\section{Investment Promotion Entity (IPE) as a Potential Means of Promoting SFM Financing}

In a follow-up to decisions by the Intergovernmental Panel on Forests (IPF) and the Intergovernmental Forum on Forests (IFF), further analyses of a proposed funding mechanism for SFM known as Investment Promotion Entity (IPE) were done ${ }^{3}$. The results of two complementary pre-feasibility analyses of the concept were discussed at the workshop.

The general idea of promoting and catalysing increased private-sector funding of SFM was welcomed, and there was broad agreement that the concept of the IPE should be explored further. Frequent reference was made to the need to promote investment in the context of national forest programmes and through partnership building between the forest sector and private investors. Suggestions were made on how to familiarise the private sector with it and to assess the sector's potential interest in such partnerships.

On the other hand, limitations of the IPE in its proposed format were recognised in relation to the needs of a wide range of developing countries, SFM activities and investors. It was stressed that the IPE should focus on a few aspects of SFM rather than attempting to serve all possible needs. It was felt that in clarifying the design of the IPE, options for its scope and orientation should be explored fully, based on the following aspects:

potential to promote large-scale private investment in countries of only medium interest to investors;

the possibility of serving a wide range of investors, from small to large; the ability to promote SFM investments in natural forests, where partnerships between the public and private sectors (commercial and non-profit) are often a key to success; and prospects for operating at a national or regional rather than global scale.

It was agreed that, subject to the availability of appropriate funding, further in-depth analyses of the IPE is warranted to provide a broader consideration of several factors important for assessing its merits. The analyses should be considered in consultation with a wide range of actors, especially the private sector. Issues identified as requiring further examination include: 
Market analysis: a full assessment and characterisation of demand, including a review of existing experiences with small-, medium- and large-scale forest-related financing in different regions (under different risk levels and country conditions), as well as provision of examples of projects and investments to be carried out by an IPE;

Review of investment experience, including experience with small-, medium- and large-scale investments;

Orientation: to what degree commercial and development objectives should be combined in projects;

Functions: fuller consideration of matters such as to what degree to focus on packaging of investment, risk mitigation, reduction of transaction costs, provision of information and clearinghouse functions;

Investment criteria, including definitions of types of SFM and beneficiaries and the benefits developing countries and countries with economies in transition can derive from the IPE;

Risk assessment: detailed assessment of risk and securing private-sector views about risk from the perspective of investors at various scales;

Organisational issues: structure, governance, operational strategy, nature of coverage and geographical scope (global, regional or national);

Financing establishment of the IPE and its operation: balance between public and private-sector funding of IPE as an institution and long-term financing issues (including means of self-financing); and

Linkages with other mechanisms: possible complementarity or overlap with existing and planned mechanisms.

Some workshop participants in Oslo suggested that undertaking pilot activities would be a useful way to learn about the feasibility of the IPE. Such pilot activities could be pursued by governments and the private sector without precluding consideration of the measure by the UNFF.

\section{Other Means of Increasing Financial Resources from All Sources, Including the Global Forest Fund}

\section{Global Forest Fund and related mechanisms}

Previous discussions about the Global Forest Fund (GFF) leading up to the fourth session of the Intergovernmental Forum on Forests were reviewed and considered in relation to interest in securing new and additional financial resources for SFM and ensuring a sustained flow of funding to it, and addressing concerns about deforestation. Some 
participants reiterated the importance of establishing a GFF for developing countries. One noted concern was that the GFF might become a substitute for existing official development assistance rather than adding to existing flows of ODA to developing countries and countries in transition. The subject of the GFF will continue to require attention.

There was also discussion of recent developments in existing international financing institutions and mechanisms that might offer new opportunities. These were considered in regard to overall international financial arrangements for SFM with which the GFF might be associated, in order to draw upon opportunities for co-operation and partnerships among the involved bodies. This is important because no single instrument can meet all the needs of the wide range of forest beneficiaries. Some participants saw a need to assess possibilities for linkages and collaboration to enhance the effectiveness of these instruments for SFM. The results of such assessment should lead to identifying various elements of an international framework for SFM financing, including possible ways of filling gaps in the existing mechanisms.

The workshop participants considered direct links between SFM and poverty alleviation and sustainable development that might open possible but so far under-utilised sources of funding, including ODA, for sustainable forest management.

Attention was also given to the fact that while the flow of financial support to the forest sector has not been sufficient, better use of these limited resources could have had a much more positive impact in moving from unsustainable practices to SFM. A number of factors have contributed to making the flow of financial resources to the forest sector ineffective and inefficient, including poor co-ordination among donors, lack of agreement on the criteria for allocating funds and poor complementarity between public and private funding, both local and foreign. In regard to this, the workshop participants considered a consortium approach and other forms of partnership as a way of addressing investment needs that cannot be met by any specific mechanism or source, and also enhancing the effectiveness and efficiency of available financial resources. The idea of partnerships and consortia, preferably operating at the national and regional levels rather than the global level, was welcomed.

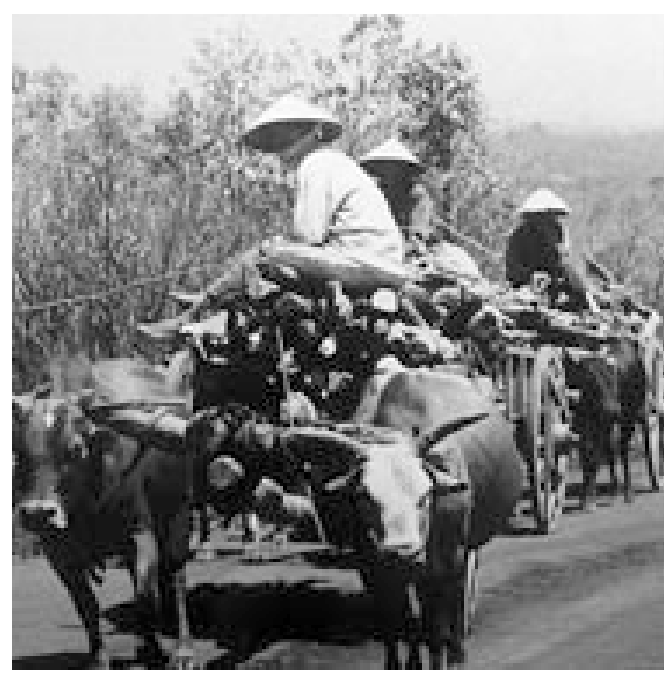




\section{Other means of increasing financial resources from all sources}

The workshop participants were briefed on: 1) recent developments at the World Bank following the review of its forest policy implementation; 2) activities of the Inter-American Development Bank, including partnership efforts to promote private-sector investment; 3) developments of the Global Environment Facility that offer more possibilities for forest sector funding; 4) the Global Mechanism of the United Nations Convention to Combat Desertification; and 5) national forest funds in a wide range of countries.

The participants observed that there is limited knowledge about the existence of many funding

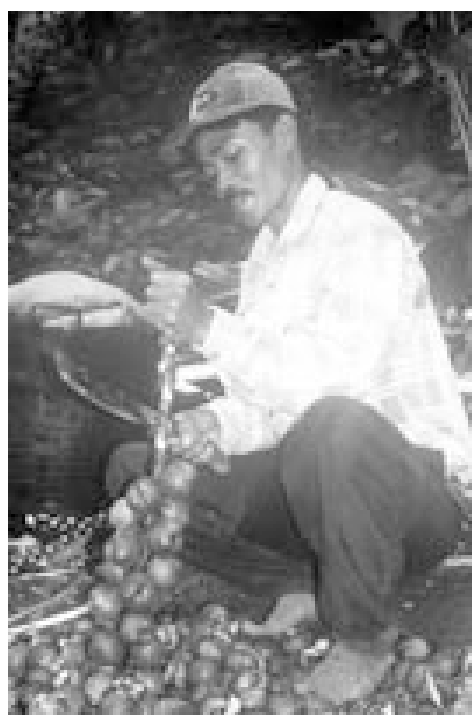
mechanisms, including some bilateral sources; therefore, wider dissemination of information about the available sources of international financing might help tap additional funding for SFM. Similarly, an agreement on guidelines of the Kyoto Protocol by the Conference of the Parties of the United Nations Framework Convention on Climate Change and the creation of an Executive Board to promote the measure's objectives may constitute a useful mechanism for channelling investments into reforestation and afforestation as part of carbon sequestration efforts. ${ }^{4}$

The workshop recognised World Bank's new efforts to complement project lending with other funding mechanisms, such as issues-based lending, greater inclusion of forest elements in broader development programmes, and systemic resource transfers. It also recognised the wide array of financing instruments of the Inter-American Development Bank to support SFM and attract investments by smallholders and both commercial and non-profit private-sector organisations.

The Global Environment Facility (GEF) initiatives to expand its activities in the area of sustainable use (through its Operational Programme No. 12, Integrated Ecosystem Management, together with its Capacity Development Initiative) were welcomed, but it was recognised that, as an environment fund, the GEF is constitutionally limited in terms of its potential contribution to SFM. Nonetheless, there should be greater awareness of the new GEF opportunities for SFM. With regard to the Global Mechanism of the U.N. Convention to Combat Desertification, it was felt that its limited success in mobilising adequate funding offers an important lesson about the importance of clarifying the objectives, functions and operational strategy of any possible new funding mechanisms before it is decided to establish them. 
At the national level, considerable experience has been accumulated with regard to forest, environmental and social funds that draw their resources from a variety of sources and serve diverse purposes, including the financing of SFM. However, there is limited analytical information on the experience with national funds, including how such mechanisms could be linked with international sources of financing. Further analysis of the potential of forest, environmental and social funds for financing SFM should be carried out to complement the information provided to the workshop by the FAO.

Finally, capacity building is an essential element in creating enabling conditions for the funding of SFM. At the international level, there is a need for greater sharing of knowledge about and opportunities for best practice in national forest programmes and strategies to fund it. Information on global market trends and the use of individual financing instruments would facilitate the learning process at the country level. Therefore, an exchange of experience among countries and regions should be encouraged.

\section{Additional Points}

The following issues and suggestions, some of which may deserve further consideration, emerged from discussions by individual working groups in Oslo:

Organise an international meeting of the private sector (including forestry and forest industry companies) on enabling conditions for private investment.

Convey the IPE idea to the Chief Executive Officers (CEO) Forum of the World Bank, with a view to securing the group's interest in launching pilot operation of the mechanism.

Disseminate information about experiences in multi-stakeholder cooperation.

Provide better information about concepts and the mix of instruments in developing concrete national financing strategies for national forest programmes.

Pay attention to the special measures needed to address the considerable investment needs of countries in transition.

Arrange for South-South exchange of knowledge about innovative funds. Expand the scope of national funding mechanisms beyond special funds for the forest sector to include further leveraging of existing sources (inside and outside the sector).

Make efforts to develop markets for environmental services (they undoubtedly will develop eventually and it is better to anticipate this outcome before costs become too high). 
Develop mechanisms to capture the public's willingness to pay for SFM services.

Analyse and examine the possible need to align priorities among, for example, GEF, other international public institutions and instruments, private foundations and NGOs.

\section{Matters proposed for particular attention by the UNFF}

The Oslo Workshop had an unusually high number of participants from commercial private-sector experts along with government officials. This provided an opportunity for direct communication about why the private sector often appears reluctant to invest in SFM, limits its attention largely to plantations and appears reluctant to invest in all but a few developing countries. A number of messages from this dialogue with the private sector, and also in general discussions, appear to deserve the particular attention of the UNFF. The issues have been included in the formal workshop report made available to the UNFF through the UN Secretary General by the six co-sponsoring governments. The UNFF has been encouraged to consider them and it may choose to act upon them directly or to recommend action at the national level.

\section{1) Ensuring an enabling environment for investment in SFM}

Taking action to make SFM attractive for private capital and to make unsustainable practices less attractive.

Making international trade remunerative enough to yield surpluses for reinvestment in SFM.

Raising the level of priority given to the forest sector by developing country governments as well as by the donor community.

Increasing the attractiveness of forest sector investments by linking them more directly to priority issues such as poverty reduction and sustainable livelihood concerns.

\section{2) Improving private-sector engagement and public-private partnerships in the forest sector}

Making deliberate efforts to effectively engage and include more people from the commercial private sector in dialogue, alongside the NGO community, which is already frequently present.

Encouraging greater public-sector investment in creating enabling conditions for natural forest management that yields goods and services of societal importance but from which the private sector cannot otherwise profit at this time. 
Giving the Investment Promotion Entity (IPE) a chance by encouraging its implementation on a pilot basis by any interested parties.

Systematically drawing attention to all viable opportunities for publicprivate partnerships for SFM investment, including through consortia or other partnerships at the national and regional levels.

\section{3) Increasing and making existing international funding more effective}

Appealing for re-engagement with and re-commitment to increased official development assistance (ODA) for forestry development and for it to reach more developing countries according to their needs.

Appealing to different existing financial mechanisms, both multilateral and bilateral, to streamline and co-ordinate their respective projects and programmes.

Encouraging further study of national forest funds and other environmental and social funds with a view to determining how they can best be mobilised toward SFM.

Encouraging the Collaborative Partnership on Forests (CPF) to increase and harmonise the collection, updating and wider dissemination to countries of information on a range of funding mechanisms and funding sources.

Agreeing on the best way forward in regard to the idea of a Global Forest Fund.

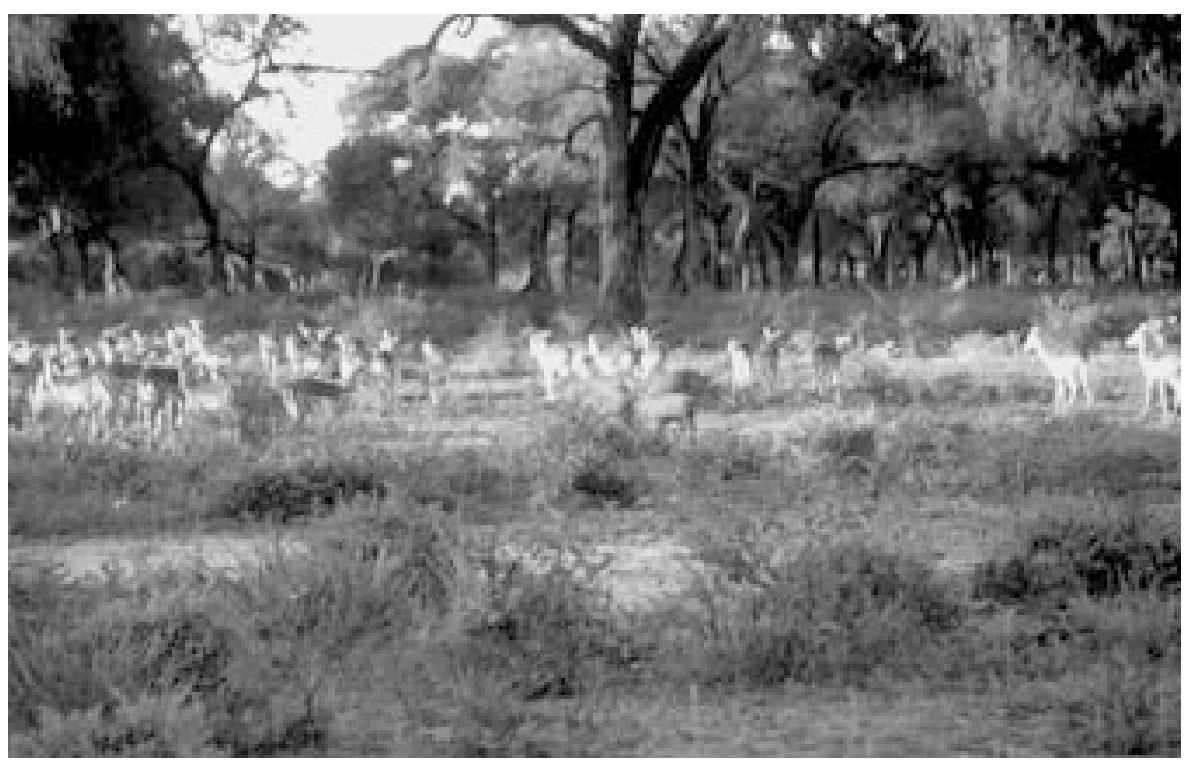




\section{Chapter 2}

\section{Workshop Discussions and Key Messages}

\section{Background: The road to Oslo}

\section{Earth Summit Origins}

The pursuit of sustainable forest management has occupied centre stage in international deliberations on environment and sustainable development throughout the period leading up to, during and following the 1992 United Nations Conference on Environment and Development (UNCED) in Rio de Janeiro (the "Earth Summit"). Given that even conservative estimates placed annual SFM funding requirements for Agenda 21 (the ambitious action programme of the Earth Summit) at some US\$31 billion and that most countries are poor, the mobilisation of international and domestic resources remains among the most critical issues. Since UNCED, the international community has therefore understandably devoted much attention to the issue of how to fund implementation of Agenda 21.

There are several challenges: the first is that the financial implications of Agenda 21 were beyond the means of most developing countries. The second is that in some cases, with or without the UNCED agenda, implementation of SFM can result in some developing countries managing their forests for benefits that would accrue partly or even largely well beyond their borders. Values such as biodiversity and climate stabilisation were among the "international public goods" seen as beneficial to the global community 
and for which developing countries wanted to be compensated through funding transfers. These countries called for new and additional financing for sustainable forest management. This, like many other questions of how to mobilise more funding, proved highly contentious, and remains so.

Mobilisation of international financial resources for SFM has remained one of the most critical and politically sensitive issues deliberated since the Earth Summit. Therefore, a brief look at the origins of the idea is useful. In the Forest Principles ${ }^{6}$ and other texts negotiated at the Earth Summit, call for specific financial resources to be provided to developing countries, as well as for the international economy to provide a climate for achieving environment and development goals.

Since the Earth Summit, the international policy debate has been led by the U.N. Commission on Sustainable Development (CSD) and associated bodies under the U.N. Economic and Social Council (ECOSOC). With regard to forest sector issues (including related financial issues), the dialogue was initially under the aegis of the Intergovernmental Panel on Forests and the Intergovernmental Forum on Forests and now under the United Nations Forum on Forests. This dialogue has led to some solutions, but often has also raised some questions; it has required additional in-depth consultations, which have occurred in a number of external, non-formal fora. In the case of finance issues, three government-led workshops on the subject have been organised. The first, co-sponsored by Denmark and South Africa, was held in Pretoria, South Africa in 1997 ; the second, sponsored by the United Kingdom, occurred in Croydon, U.K., in $1999^{\circ}$. As a follow-up

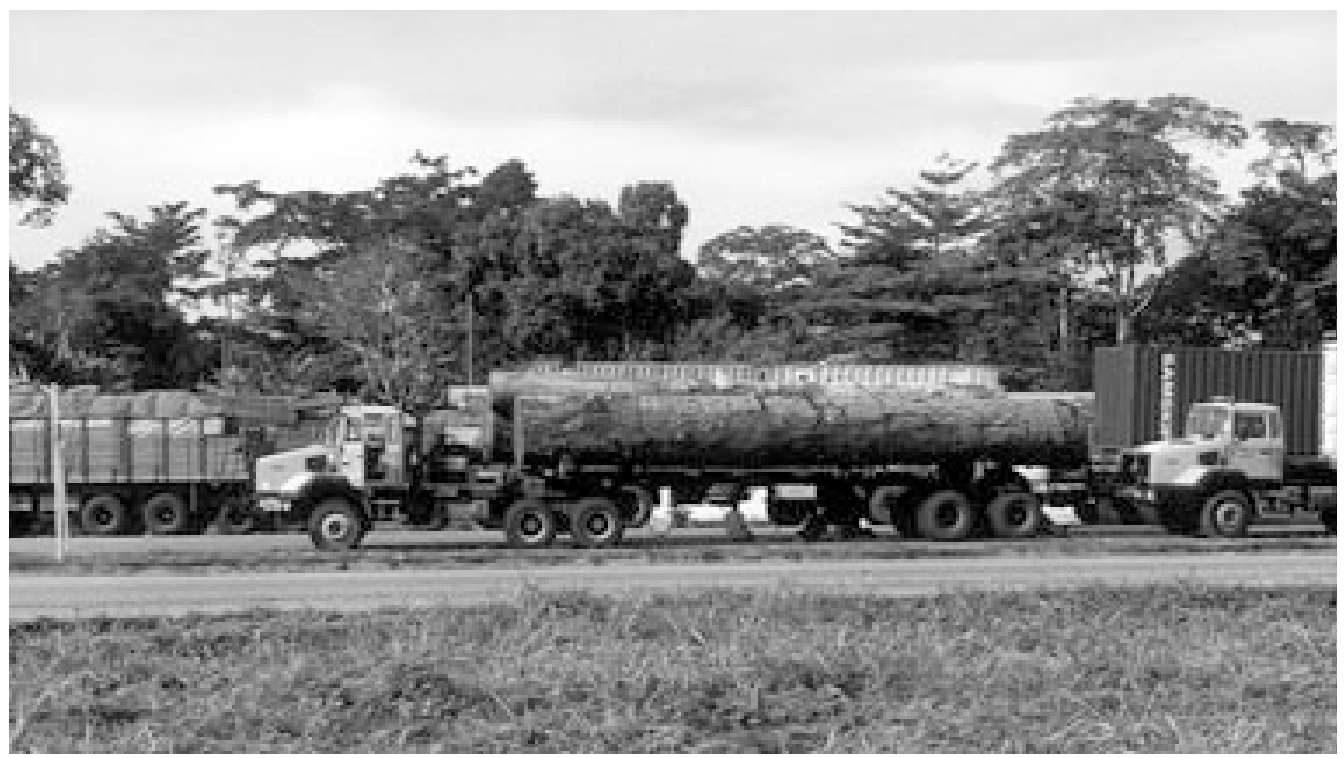


to these two meetings, an International Expert Meeting on Financing Sustainable Forest Management, the focus of this report, was held 22-25 January 2001 in Oslo, Norway. The Oslo Workshop faced the same issues that participants at the 1992 Earth Summit grappled with, such as calls for new and additional financial resources and compensation for international public goods beyond the needs of developing countries. And, like before, contrasting views about many of the core issues remained intractable.

\section{The Intergovernmental Panel on Forests (IPF) and the Intergovernmental Forum on Forests (IFF)}

The IPF, established in 1995, was the first intergovernmental forum to comprehensively deliberate all forest-related issues, including financial co-operation to support SFM. The 1996 workshop in Pretoria helped the IPF define the scope of its deliberations. The IPF produced a number of proposals for action that dealt with mobilisation of domestic resources, concessional funding (including ODA), private funding, policy reform and debt relief ${ }^{9}$. However, it did not achieve consensus on a proposal to establish an international forest fund to support SFM activities. This and other issues were left to be considered in the official dialogue that succeeded the IPF.

The IFF's first discussion of finance built upon the outcomes of the IPF was held at its second session in 1998; this was followed by substantial attention to the issue at the forum's third and fourth sessions (in 1999 and 2000). The negotiations proved difficult from the beginning. The United Nations Development Programme (UNDP) and the IFF Secretariat commissioned four in-depth studies in 1999 to facilitate the work of the IFF ${ }^{10}$, and the UNDP convened the U.K.-sponsored workshop in Croydon in 1999, which proved particularly useful during the IFF's final negotiations on finance.

\section{Foundation for the Oslo Workshop}

At its final session in 2000, the IFF achieved consensus on nine conclusions and a set of five proposals for action. Among the new concerns that emerged from the IFF was recognition of the need for better data on financial flows and interest in the concept of an Investment Promotion Entity (IPE), which could mobilise private investment and promote public-private partnerships for investment in SFM.

In the IPF and IFF processes, it was agreed that governments should undertake a number of key tasks that included increasing financial resources from all sources, improving the absorptive capacity of resources, giving priority to forest-related issues in national policies, 
strengthening national forest programmes, resolving debt problems, addressing the particular needs of countries with low forest cover, reforming policies to encourage privatesector investment in SFM, operationalising the proposed Investment Promotion Entity (IPE) and improving financial flow information and databases. Notwithstanding shared views on these topics, by the end of the IFF process, much had been left unresolved. As a result, these proposals for action remained to be addressed and taken up to the extent possible by the Oslo Workshop:

Continue efforts to explore, identify and develop new, improved and more effective financial mechanisms, and further explore the potential and results of innovative use of existing mechanisms to promote sustainable forest management;

Create an international forest fund ${ }^{11}$ to support, inter alia, additional costs incurred during a transition period toward sustainable forest management;

Fully utilise the potential of existing mechanisms, such as GEF, consistent with their mandates, and explore possible options for expanding their scope to finance a wider range of sustainable forest management activities;

Consider the need for a study that integrates such issues as the valuation of forest goods and services, including biological resources, and the international trade of forest goods.

Despite the preparatory Croydon workshop, the IFF was also unable to reach consensus on a few critical issues related to existing as well as proposed new mechanisms such as carbon offset functions of forests (under the Kyoto Protocol), the concept of compensating landowners for environmental services from their forests, and reviewing existing mechanisms, such as GEF, to make full use of their potential to support SFM activities.

\section{Selected Overarching Issues in the Funding of SFM}

Prepared papers and participants' input at the Oslo Workshop offered a wide range of views and examples related to current financing of SFM. (Summaries of the papers are provided in Part II of this report.) From the papers and discussions, some areas of overlapping interest, concern and agreement were apparent, especially with regard to observations of what factors constrain private-sector involvement in SFM and what is necessary to change the situation and encourage such investment. The problems are 


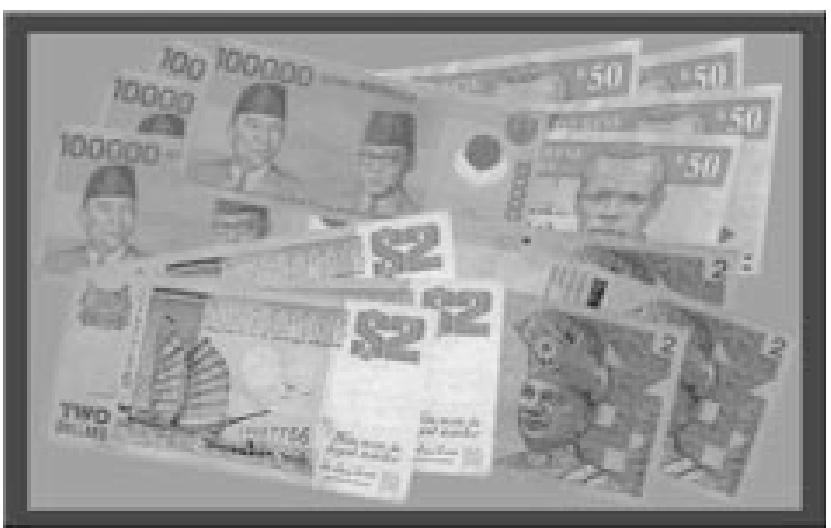

of their significant deterrent effect on investment: 1) the poor competitiveness of the forest sector in general and SFM in particular; 2) low priority accorded to forests and SFM by developing countries, donors and external partners alike; 3 ) a perception that SFM is risky as an investment option; and 4) idealistic and unrealistic expectations of achieving progress toward SFM in relation to every forest, which are seen as overly ambitious and likely to fall short of the mark, thereby discouraging potential investors.

This last topic, which was raised by private-sector experts from Africa and Latin America, is a relatively new issue in the dialogue on SFM financing. It is important because it relates to questions of motivation and encouragement, which is crucially important in making the private sector a willing partner in "mainstreaming" SFM.

Issue No. 1: Competitiveness of SFM as an investment option - For SFM to be adopted as a mainstream way of doing business, it must be demonstrably competitive relative to non-sustainable forest management practice and to alternative investments for land use or provision of livelihoods. ${ }^{12}$ Whether small farmers or corporations, those who decide whether to clear forests are usually swayed by financial returns rather than by the economic value to society of retaining those forests, however high that value may be. Accordingly, bold decisions will be needed to make the SFM option attractive.

It was generally accepted that where there is genuine interest in mainstreaming SFM and realising its potential achievements, public intervention - in the form of policies, resources and efforts - may be needed to create the conditions under which SFM is truly a viable alternative. Among the proposed solutions were:

public investment - of varying degrees - in the forest sector to secure "public goods" values that the private sector and individuals are not prepared to pay for; 
government establishment of property rights for some services of forests that are not currently marketed, thereby providing private or profit-driven opportunities to drive investment;

intervention at the global or lower scale to make markets more remunerative and stable, which would better enable the private sector to generate surpluses that could be used for reinvestment;

expanding markets for new environmental services of forests so that with increased revenues added to income from traditional goods, industry can better absorb the growing costs of SFM;

reducing the costs that producers face, in areas such as heavy regulation and legislation, which raise costs unduly while the market remains unwilling to pay related price premiums and society is not yet ready to share the burden;

making sure that alternative uses of land are not made unfairly competitive compared with the forest option because of unwarranted subsidies and other policies with perverse impacts.

A fundamental question that was raised is whether forestry is necessarily the best way to achieve all the objectives that society seems to expect of it.

It was recognised that if the private sector is to contribute effectively to SFM, the conditions must be such that investors can realise profits from that involvement. A central question is how that can be achieved if the private sector is expected to assume costs associated with efforts to also satisfy broader environmental and social goals. While the workshop produced no answers on how to address this, there was nonetheless apparent agreement that the private sector should not be entirely exempt from "good citizenship" obligations to pay its share of societal costs. Nevertheless, governments (acting as proxy for society in genera), invest"13 in meeting the "societal" costs of practising SFM, thus creating a basis for public-private partnerships. It was also argued that more favourable policy, institutional and regulatory factors would make the forest sector a much more attractive investment option, and if such measures were in place - both within and outside the forest sector - public financial investment needed to help meet societal costs of SFM might be reduced.

Discussed in relation to the competitiveness of SFM was the role of forest product certification (designating that products have come from sustainably managed forests), which some markets currently demand. The intentions behind certification are good. Two viewpoints were presented regarding practicalities: one was that despite its unquestionable merits certification adds costs at a time when these higher costs are not yet balanced by consumers' willingness to pay an associated price premium ${ }^{14}$. The second view was that certification may currently not always help win new markets or raise 
profits, but it can protect existing market share and should therefore be regarded as worthwhile. Important to remember is that while certification costs may not be unduly onerous for large firms, they can be a significant hurdle for small-scale forest owners and those in the informal sector, effectively working against this group of producers.

Issue No. 2: Low priority given to the forest sector and SFM - SFM and forest activities in general are given low priority by national governments in developing countries and the donor community, as reflected in limited resource allocations to the sector. As noted earlier, this occurs in part because of perceptions that the forest sector is comparatively a poor option for land use or investment and has little relevance for development. Accordingly, notwithstanding pro-forestry pronouncements, government actions often suggest poor commitment to the sector.

Papers presented in relation to discussions about possible opportunities for consortium funding indicated that among key multilateral funding organisations, the demand for lending to the forest sector is low and, in some cases, declining. Many developing countries do not regard allocating resources for long-term SFM as cost-effective, and believe that greater benefits accrue from directing investments and social expenditures to other areas, such as combating poverty and reducing national indebtedness.

The situation was best expressed by Kufakwandi in relation to Africa. He observed: "The question of funding sustainable forestry development programmes, and the adequacy of funding to forestry, needs to be considered in the overall context of competing claims. Many African countries, in their day-to-day struggle to satisfy the most basic needs of their populations, are unable to take a long-term view, which is the time frame required for the successful implementation of sustainable forestry management programmes."

Issue No. 3: A perception that SFM is a risky investment option - Developing countries are generally seen as more risky; as a result, investors who do invest in developing countries often require a higher rate of return and a shorter term for payback to minimise their exposure. Because it is for the long term, sustainable management of natural forests in developing countries is therefore at a disadvantage in attracting investors.

Commonly recognised types of risk are associated with exchange rate fluctuations, inflation, inventories and pricing, and political conditions. Moura Costa et al. used different categories of risk - sovereign, financial, contractual, market, project performance and natural disasters - any of which can jeopardise commitment by prospective investors. The generally longer time periods involved in SFM compared with unsustainable timber extraction cause even greater private sector attention to risk..

Profitable sustainable forest management projects can be found in the developing countries, but it is still difficult to convince Western (North American and European) 
institutional investors of this and to interest them in such investment. The less familiar a country or site is, the more wary a prospective investor is likely to be; the level of risk in unknown, partners are new, and the country's culture and business practices are unfamiliar. Add to this the unsteady political circumstances, and most Western investors will consider investing in SFM in developing countries or countries in transition, only if a much higher return (typically 15 to 30 percent) is likely.

One measure that may help reduce concerns about risk among foreign investors is a trend of increased domestic investment in the forest sector. Risk guarantees would also offer greater assurance; these might take the form of direct guarantees from the government (if it has a suitable credit rating), from an international third

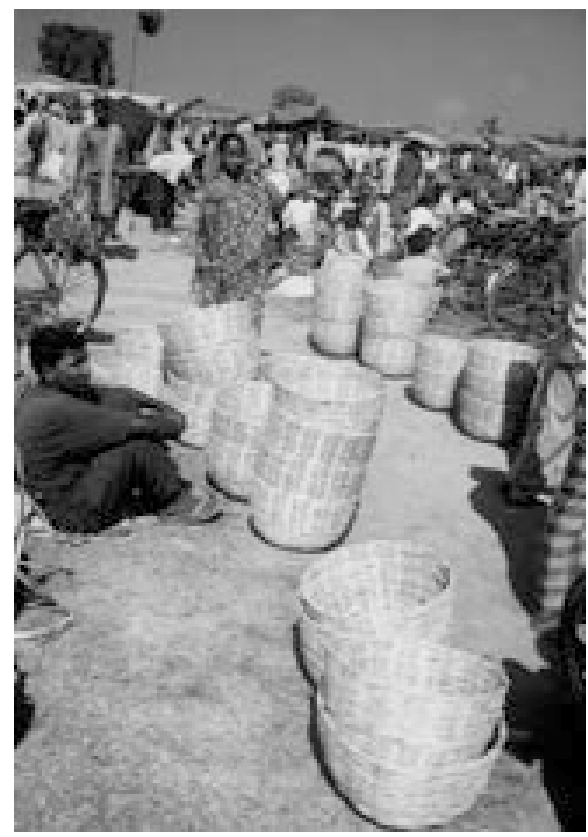
party or through investment partnerships with public institutions or the government itself. The World Bank, for example, recently provided a partial risk guarantee to attract external private-sector investment in Russia's forest sector. Using a guarantee instrument has the advantage of not requiring major financial outlays to implement.

Issue No. 4: Idealistic and unrealistic expectations with regard to achieving progress toward SFM - One clear message from workshop papers by authors representing the private sector in African and Latin American countries was that perfection is the enemy of the good in efforts to achieve SFM. They charged that society (or at least vocal elements within it) remains unrealistic about how quickly SFM can be adopted and practised in the field ${ }^{15}$. Thus, incremental progress is dismissed as discouraging because it falls short of fully realised SFM. At the same time, laws and regulations adopted to engender full achievement of SFM are accumulating, and the private sector, in its efforts to comply with these requirements, faces escalating management costs that are not matched by correspondingly higher prices for its products.

This situation raises the question: With so few forests being managed at all, why is achieving "perfect" SFM for a few managed forests emphasised rather than improving management of the much larger pool of forests that are now mismanaged or not managed at all? The question got relatively little attention in Oslo, although due to greater attendance by private sector experts, the issue was more prominent than at previous meetings on SFM financing. Two aspects of the question were addressed in workshop papers. The 
first was concerned with whether SFM can be realistically pursued for every forest (microscopic SFM) or is better done at a landscape level (macroscopic SFM). The private sector sees problems and inefficiencies in the first approach, and considers it impractical; it favours instead a macroscopic approach in which a diverse range of specialised forests together could be managed to meet the various attributes of SFM. Gregersen and Contreras observed: "In fact, in most countries, we are dealing in practice with a point on the continuum between the two extremes."

The second aspect of the question focused on the earlier mentioned idealism that seeks rapid achievement of SFM and fails to acknowledge progressive improvement. Landrot and Speed reported that in Africa, for example, most large NGOs have only recently become more pragmatic with regard to ideas about a number of issues, such as requirements for biodiversity protection, expectations about how quickly economic and social development can be achieved, limitations in the ability of forest companies to solve problems of ethnic minorities and the destruction of fauna and the realisation that local problems in developing countries cannot be solved by imposing western practices and concepts.

In relation to Latin America, Raga Castellanos noted that some NGOs support strict definitions of SFM that often prove to be quite expensive and fail to acknowledge "sound forestry practices," such as ISO 14000 standards, that do not fully meet the organisations' ideal requirements. This situation discourages investment in SFM because the targets seem troublesome, expensive and perhaps unreachable. Tomaselli noted that besides the tendency to overlook progressive improvements in favour of demanding full achievement of SFM standards, there is a lack of incentives to encourage the adoption of best practices.

Tomaselli described the case of Bolivia as one in which the "rush to reach perfection" has adversely affected production. In 1996 the Government of Bolivia adopted a strongly proSFM law. However, the law failed to consider the need for a transition period. In the short transition time frame, the private sector was not in a position to deal with the new and additional costs related to sustainable forest

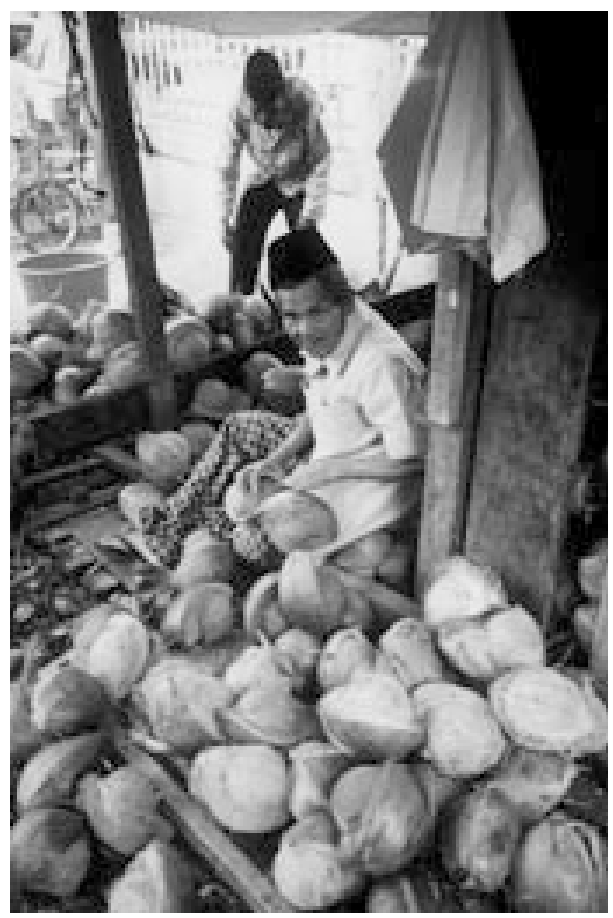


management along with the costs of meeting the new regulatory measures. Moreover, the new requirements were introduced at a time when the international market for tropical timber was hurt by the Asian financial crisis. As a result of the increased costs and reduced returns stemming from low market demand and price collapse, the private sector of Bolivia shrunk in the last two years. "Prospects for the near future are not good," Tomaselli reported. "Private-sector debts are out of control and companies have no way to further invest in SFM, as investment to reduce debt became a priority to continue to work."

\section{The Importance of an Enabling Environment for SFM Investment}

The importance of an enabling environment for attracting investment into SFM and for making capital effective was amply recognised in the Oslo discussions and in many papers prepared for the workshop. In his presentation to the workshop, Ljungman introduced this topic, which led to one of the key messages of the meeting: that financing of forest sector development is constrained more by weakness in or lack of enabling conditions than by a lack of funds, and if this situation is not corrected, the sector will not be able to attract funds or effectively use any funding that may already be available. "Enabling environment" encompasses a broad range of factors, including global economic and trade issues; national macroeconomic, social and political circumstances; human and institutional capabilities; and sectoral policies, institutions and incentives.

In discussing a suitable environment for SFM investment in Latin America from the perspective of the Inter-American Development Bank, Keipi highlighted the importance of political and macroeconomic stability, access to land, property rights, an effective and appropriate regulatory framework, clear forest policies, and participatory decision making and policy

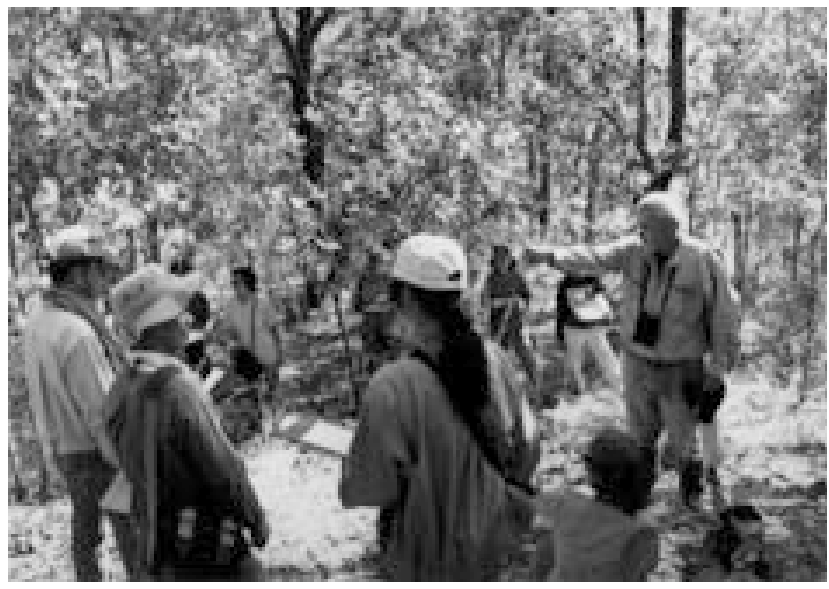
execution. He also gave weight to fostering ethics and transparency in governance and business. To engender competitiveness, he called for strengthening infrastructure and financial services as well as supporting forest business development more directly. In Keipi's view, the availability 
of suitable rural credit may become the most important element in aid to productive forestry. ${ }^{16}$

Whether in relation to Africa, Asia or Latin America, all the workshop papers on privatesector investment in SFM stressed the importance of policy and regulatory issues as a major factor. Business, of course, depends on the existence of reliable civil laws and of court systems to enforce them, especially to settle property rights-related and other legal disputes. Among other things, the papers noted that lack of property rights constrains the emergence of markets for environmental services of forests, while excessive and inappropriate regulations and bureaucracy contribute to unduly high costs of forest management ${ }^{17}$. The various papers also described other factors that work against an enabling environment for SFM investment, including:

the dispersed location and informality of small-scale forest owners; unstable and unclear policies in relation to tenure and concessions; inadequate government commitment to and support for the sector, specifically through too little investment in public infrastructure, thereby putting an additional burden on private investors;

the lack of an instrument to hedge against market fluctuations and of a mechanism for price determination in international markets; the willingness of major markets to buy low-priced supplies from unsustainable sources, thereby undermining, through unfair competition, producers that try to conscientiously move toward SFM; training and skills development and research; corruption; and political instability, including wars ${ }^{19}$.

Problems in individual countries were described. Haeruman noted that in Indonesia, existing enabling policies are now out of date because the country has decentralised fiscal and administrative decision-making; as a result, the current system of financing national parks is no longer appropriate. Petrov lamented that in Russia, the decree-based system of setting stumpage fees and other charges give forest owners and managers woefully little income to use for reinvestment. For Norway, istad attributed the success of the public-private funding system that accounts for most investment in resource management to good organisation of the many small forest owners and to sound policies and institutions, including a clear regulatory framework, support and guidance from local government, and strong extension and technical support services. Nguyen reported that in Vietnam, reforestation efforts have encountered much difficulty because planners have poor information about prospects for profitability and economic viability; there is poor monitoring as well as bureaucratic delays in funding; it is hard to find long-term credit and the amount of collateral demanded for borrowing is a hurdle; and farmers prefer to invest in options that offer quicker returns than forests and trees. 
In her commentary on the debate, Lai Har Chan elevated the issue of an enabling environment for SFM above the national plane. In her paper focussing on the international economic and trading context for SFM, she argued that the "preoccupation with national enabling conditions remains important but, with globalisation, is no longer sufficient." Three problem areas she identified as undermining favourable conditions for investment in general but also applicable to SFM investment at the international level are the global trading system (commodity prices declining to un-remunerative levels); governance (uncontrolled corporate currency movements destabilising economies and adversely affecting their investment attractiveness); and the multilateral system (locally non-adapted generic restructuring prescriptions for correcting economic crises, leading to economic contraction and unattractiveness for investment).

\section{Improving Private-Sector Engagement and Public-Private Partnerships in Forest Sector Investment}

While the private sector is an important player in SFM, there are many kinds of private investments and investors; they cannot be viewed as a single entity. Thus, it is important to recognise the specific interests, capabilities and constraints of various investors and fields of investment, and to devise appropriate policy incentives that address these differences. The private sector may be represented by: a) foreign investment by large multinationals and local investment by local companies; b) highly regulated companies as well as those with looser regulation and less regard for international public image; c) individual private investment, such as SFM-related conservation activities by philanthropists and community investment in SFM; and d) small-scale forest owners.

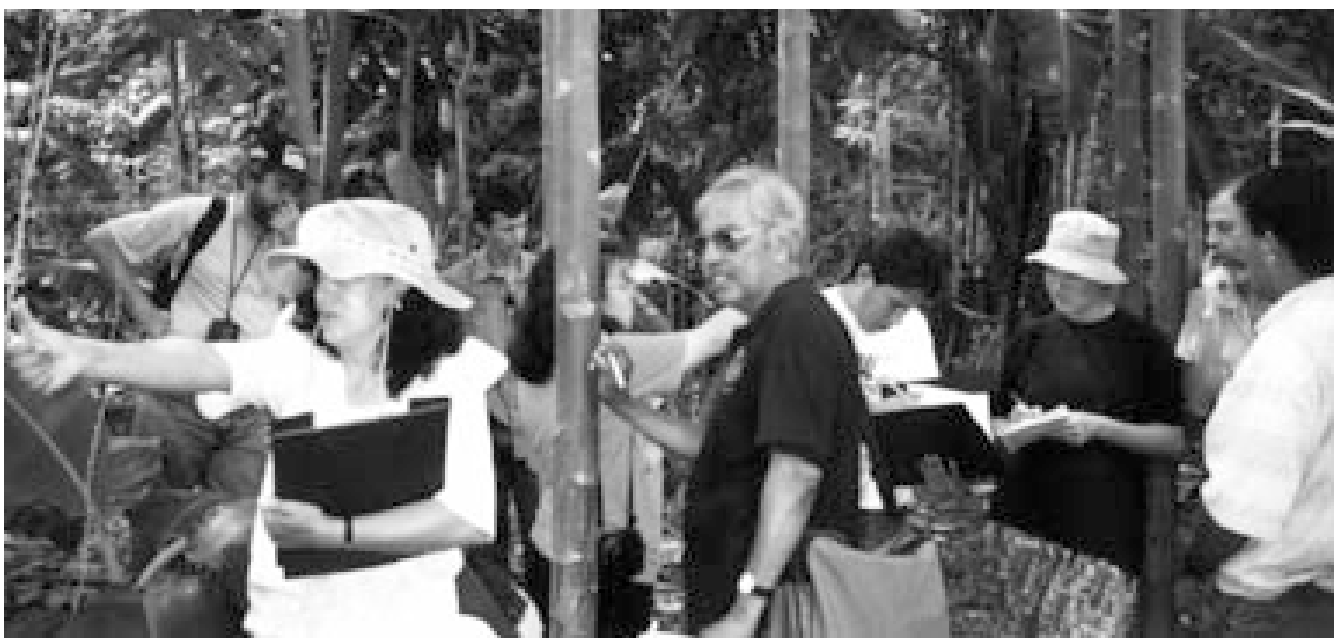


Ownership may involve corporate or joint investment arrangements, purely private firms or public-private partnerships, and either direct or portfolio investment.

Profitability and the competitiveness of forest investments relative to alternative options are two major factors influencing private-sector involvement in SFM; a third is concern about risks. The reality is that long-term sustainable forest

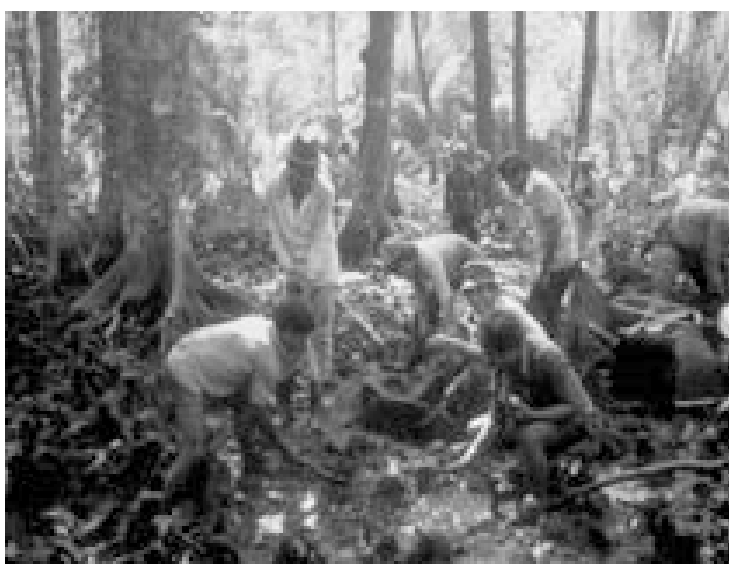
management is often financially unattractive compared with unsustainable practices, and private investors are not inclined to make the kind of large investment that is needed to "mainstream" SFM.

In his lead paper that laid out key questions of the workshop, Gregersen emphasised the importance of increasing the profitability of SFM to levels that are high enough to attract private investment and reducing risks that discourage $i^{20}$. As Tomaselli noted, "The market is, in the end, the main source of funds to finance SFM." In relation to that, the following issues must be recognised and addressed:

The private sector is wary of being burdened with the costs associated with providing societal benefits at its own expense. Meeting many public goals of society at private cost, which amounts to altruism, is not compatible with high profitability; when the private sector does so, it is effectively subsidising public treasuries or society. Barney Chan observed that "SFM has too many benefits which are not enjoyed by the private sector alone to be treated as the sole or main responsibility of the private sector." $\mathrm{He}$ argued that the public sector must be a critical partner in implementing SFM; otherwise, private investors will not be interested. Raga Castellanos suggested that a reasonable approach to sharing responsibility would be for the private sector to adopt and pay the costs of meeting the basic requirements toward achieving "sound practices," while society, if it demands fuller realisation of SFM, should be willing to help finance the private sector's production of "public goods".

The private sector is reluctant to invest in management of natural forests. Private investors finance many logging ventures in native forests, yet a large number of them are not engaged in sustainable management of those same forests. When it comes to forest management, the private sector prefers to put its money into plantations rather than natural forests. One reason for this, especially in Latin America, is the availability of targeted 
incentives for plantations, but the main reason is that plantations are more predictable in their yields (generally having higher productivity) and therefore less risky. As indicated in the Highlights of this report, the reluctance to invest in natural forests (other than for logging) also arises from perceived complexity, possible high costs, and contentious social and policy issues (such as indigenous people's rights and environmental objections to harvesting of primary forests).

The private sector often regards investment in SFM in developing countries as risky. As shown in Box 1, risk is highly placed among the criteria the private sector uses to assess prospective investments. The manner in which this issue of risk influences the private sector has been presented earlier under the section "Selected Overarching Issues in the Funding of SFM". Globally, investors are predominantly from developed countries and their relatively limited knowledge of conditions in developing countries and countries in transition tends to promote a precautionary approach to risk, especially given that forest investments involve long-term commitment.

The private sector is exploring "environmental services" as a new frontier for investment. Forests are increasingly seen as the reservoirs and producers of many environmental services for which the demand is increasingly being reflected in markets, including carbon offsets, clean water and other watershed benefits, and biodiversity conservation. At the same time, in some places eco-tourism is rapidly coming to parallels industrial forest products markets in importance. Some people have predicted that the forest sector will evolve into primarily an environmental services one, with timber and energy as by-products. The private sector is studying possibilities, and according to Brand, some are optimistic. A key issue in the emergence of markets for environmental services of forests is the need for property rights arrangements that guarantee the exclusiveness of control necessary to make the profitable sale of such services possible.

Small-scale private forest owners face particular challenges. As described in a paper by istad, Norway offers an example of how small-scale forest owners can invest successfully in SFM when effective and appropriate policies and institutions are in place. Yet developing regions still have far to go in this respect. In his discussion of conditions in Chile and Argentina, Raga Castellanos describes how difficult it is to promote "sound practices" among small and medium-sized operators operating within an informal economy, who are usually poor, have low levels of education and information, and often operate without management plans. He urged increased attention to this investor category, where many problems of forest management are centred. Similarly, Landrot and Speed noted that in humid tropical Africa, national forest concessions are often small enterprises, some operated informally by families or villages that often seek quick profits with little attention to long-term sustainability concerns. 
Box 1. Private Sector's Criteria in Assessing Prospective Forest Sector Investments

1. The criteria that management organisations use to assess timber investment possibilities are a good benchmark of the requirements of global capital:

Risk and uncertainty vs. return (uncertainty is particularly acute for international investors, where firsthand local knowledge is lacking): In countries without well developed institutions, markets and technology, investors require very high rates of return and, for shorter term, locked-in cash flows, where uncertainty can be avoided. This explains why much forest sector investment in developing countries today is short-term financing for timber harvesting.

Investment structures, liquidity and investment periods: Most institutional investors in forestry are willing to accept an investment term of a decade or more. Liquidity is an important element of investment in forests. Complex regulations on foreign ownership or lengthy approval procedures for changes in title or business ownership are an impediment to liquidity.

Cash flow and time to cash flow: Buying existing mature forests should allow immediate access to cash flow from timber harvesting.

Land acquisition: Investors generally look for secure ownership of resources, usually through a logging concession or lease. For long-term management, however, investors often require land ownership or legal title to the forest being managed. Reputation and ethical issues: Organisations that manage professional investments avoid activities that may provoke negative response from key interest groups. These issues are magnified in the forest sector; for example, there is a significant risk to reputation in relation to harvesting of primary forests, concerns about the rights of indigenous peoples and other issues. This helps to explain institutional investors' reluctance to become involved in native forests. Certification can aid investment by helping to provide investors with greater assurance in regard to some of the above concerns.

Source: Summary from Brand (2000), summarised in Part II of this report

\section{For individual timber assets investor firms, the most significant investment criteria in relation to countries are:}

\footnotetext{
Relative risk (political stability, ethnical and legal framework, financial stability) Land tenure rights

Government interest in and support for forestry (as indicated by tax, legal and regulatory environments, and whether an investment is considered a "project of national interest")

Global competitiveness (access to world markets, quality of infrastructure, availability of a quality workforce)
}

Source: Summary from Mertz (2000), summarised in Part II of this report 
Certification is often seen as an assurance of responsible management. In a number of countries, the private sector has sought recognition for complying with SFM criteria through certification, which is gaining increasing favour. According to Muthoo, the Forest Stewardship Council's experience is that conformity with a set of agreed standards has the potential to encourage investment if there is a meaningful advantage, especially a market advantage. Currently, certification increases management costs, while product prices may not increase commensurately. The main benefits sought, however, may not be in terms of price but in consumer perceptions of environmental and social responsibility, although in the long term the profitability outlook may also improve. South Africa, one of the world leaders in the adoption of certification, has shown that plantation forests can satisfy sustainability requirements and still be profitable and competitive in world markets. Certification alone is not a panacea, however, and small local firms face difficulties in protecting their market access through certification.

Incentives. Latin America is a model for success in using fiscal incentives to promote private investment in forest development, but such success is still limited to forest plantations. No incentives have been identified that promote the funding of sustainable forest management of native forests. It is noteworthy that the major incentive programmes all occurred before the era of structural adjustment programmes and the growth of resistance to anything that might be construed as a "subsidy". Some participants in the Oslo Workshop felt there is still a strong case to be made for incentives in a sector that is valuable to society but otherwise cannot compete commercially. Tomaselli suggested that incentives should be used not only to catalyse the adoption of SFM but also to ensure enhanced performance and sustained practice of SFM.

\section{Investment Promotion Entity (IPE)}

The Oslo Workshop's consideration of the feasibility of implementing the Investment Promotion Entity addressed a specific IFF proposal for action. The IFF followed up on the U.N. Economic and Social Council's desire to explore the "functions and circumstances under which such an entity would operate as well as its scope in relation to the existing financial mechanisms." In the IFF's conception, the IPE would serve as a mechanism for interface between the public and private sectors and project developers and financiers, providing a means to develop innovative partnerships to fund sustainable forest management projects.

Moura-Costa of EcoSecurities presented the findings of a feasibility study on the IPE concept, which Simula of Indufor complemented with a presentation on "demand and supply" assessments by Salmi et al. The IPE would help remove barriers to private investment in SFM through activities such as provision of information, project structuring, 
financing, raising capital and providing risk mitigation. It could be launched with startup public funding of about $\$ 12$ million over four years, after which it would achieve positive net cash flows and become entirely self-financing; accordingly, "replenishment" of public funds should not be necessary. To ensure early success, the IPE would begin with more familiar kinds of projects and concentrate on supplying attractive projects to the market, beginning in a few countries. Early demonstrable success would probably be best assured by targeting large and medium-scale private investors, which would lead to sizeable deals.

Salmi et al. estimated that the demand for SFM investments in developing countries could reach and even grow beyond US\$ 15 billion per year; the IPE's share of the market would be a few hundred million US dollars in five years for all client categories. In general, Moura Costa et al. and Salmi et al. concurred that there is ample unmet demand for financing of SFM in developing countries and countries with economies in transition, and there is a significant potential supply for SFM financing from various sources that the IPE could access as a result of its dual private-public profile.

In answer to some concerns, the participants were assured that the IPE would not duplicate functions of existing institutions. Too, there were questions about whether the proposed IPE would be able to facilitate investment in natural forest management and in the least developed and low-forest-cover countries, where the funding is most needed. While no assurance could be made, the desire to achieve early success in the use of the instrument suggests that such outcomes would be unlikely. Overall funding flow through the IPE, it was pointed out, would be modest relative to needs. Further study of these and other issues is required.

A key question at the Oslo Workshop was whether to proceed with the IPE; no direct decision was made, but participants did welcome the idea of pilot activities by interested parties to explore implementation. It was also suggested that the concept be considered by the CEO Forum of the World Bank.

\section{Global Forest Fund (GFF) and Related Mechanisms}

\section{The GFF}

In summarising the current status of international policy deliberations on a proposal to establish a Global Forest Fund (GFF), Joshi of the UNFF Secretariat noted that this has been one of the most politically sensitive policy issues in the dialogue on forests. Many see the GFF as needed to meet calls at the Earth Summit for new and additional funds to, 
among other things, pay for the global environmental services provided by forests and to underwrite the transition from unsustainable to sustainable forest management of forests. Detractors are concerned that the GFF would merely reallocate official development assistance, rather than contributing "new and additional" resources. There was agreement on the need to continue dialogue on this topic.

\section{Consortium funding}

Also in relation to the mobilisation of new and additional resources, Ganguli laid out the rationale for consortium funding for SFM. The approach's advantage, he noted, is in "leveraging new, additional and stable funding to enable investment in activities that hitherto were beyond the abilities of individual or groups of individual funding bodies to address." The approach is already common practice for major endeavours in the private sector, and it is not confined to the international level but can also be applicable to national funding. Presenting an African perspective on the issue, Kufakwandi cited "complementarity" between public and private sector finance for forestry development as the biggest advantage of the approach, which he suggests could lead to long-term commitments to forestry development on the part of donors, the private sector and governments.

Preliminary reaction from representatives of development banks, international organisations, bilateral donor agencies and private companies indicated that donor countries welcomed a consortium approach, with reservations. All stressed the need for harmony with and non-duplication of other initiatives. Some multilateral development banks saw the approach as positive; in the private sector, consulting firms seemed most enthusiastic. For its part, the aid community appears to prefer participation in consortia at the level of specific investment opportunities (projects and programmes) rather than institutionally. Overall, there was greater support for ex-post consortium arrangements (that is, convening consortia for a particular programme or project) than for open-ended permanent association. Further study of the concept was encouraged, especially at the regional and national levels rather than globally. 


\section{Other Means of Increasing Financial Resources from All Sources}

\section{International Funding Mechanisms}

Presentations by the World Bank, the Inter-American Development Bank (IDB), the Global Environment Facility (GEF) and the Global Mechanism of the UN Convention to Combat Desertification (UN-CCD) ${ }^{21}$ on international funding mechanisms formed the basis for discussion. These were considered in the context of steady global decline in lending and aid to forestry. Direct financing levels in the forest sector by both the World Bank and the IDB declined during the 1990s; the forest sector's share never exceeded 2 percent of the total investment in the case of the World Bank, while it declined from about $\$ 100$ million to less than $\$ 40$ million annually in the case of the IDB. However, investment in non-forest sector activities that have the potential

to affect forests is much higher, notable examples being rural and infrastructure development and mining activities. Similarly, structural adjustment lending and other support to the financial sector can have significant impacts on forest management and also on the ability of countries to attract private sector investment.

In his paper, Douglas of the World Bank questioned whether SFM was necessarily the best solution to some of the problems for which it is being promoted. Challenging the performance of the international donor community to date, he suggested forests should be financed because, from an environmental

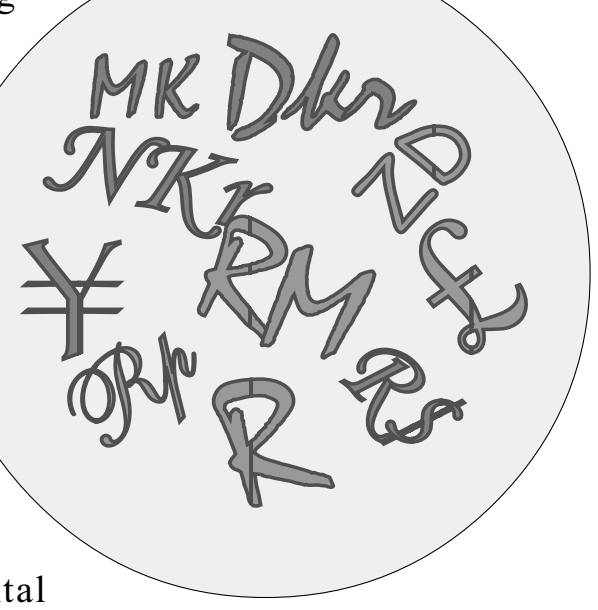
economics standpoint, forest loss and degradation (often caused for private gain) imposes damages on broader society, and particularly on the poor.

Douglas said the international community should focus its funding not necessarily on regulating logging in natural forests or the most commercially valuable forests, but on other priorities that may help prevent complete loss of forest cover as a result of extrasectoral pressures to convert land to other, low-value uses. Areas he identified as needing particular attention include support for infrastructure; systems for enforcement of laws, taxes and environmental service agreements; payment systems for environmental services; mechanisms for tradable development rights to compensate those who bear the costs of 
conservation; sanctions or disincentives for actions that threaten forests; and diffusion of knowledge and development of innovations that foster better forest management.

For Latin America, Keipi urged private investment not only for production forests but also for protected areas, ecotourism and conservation set-asides. Notwithstanding the current problem of limited demand for forest investment lending, he sees many opportunities for future investment, and called for increased awareness about this prospect among influential audiences such as ministries of finance, national planning agencies, the commercial banking system and rural credit institutions. He outlined some innovative funding approaches, paid much attention to enabling environment issues, and stressed the future importance of rural credit for retailing forest-related finance.

Kumari told the workshop participants that the forest operational programme is the largest recipient of funds from the Global Environment Facility, and will remain a very important part of lending by the GEF, which has allocations of $\$ 505.92$ million from its own sources and more than $\$ 1.03$ billion in co-financing. She reported that some flexibility is being introduced that would expand the GEF's involvement in forests beyond protected areas; in the future, activities in broader landscape mosaics and even production forestry may be eligible for assistance. The GEF also plans to change the way its addresses sustainable use and conservation, by pursuing more comprehensive and integrated approaches; the project-based approach will be maintained, but enhanced by strategic interventions aimed at creating a more enabling environment for SFM in recipient countries. The workshop participants urged efforts to better publicise changes in the flexibility of the GEF and the opportunities it offers to promote SFM.

Ryden briefed the workshop participants on the Global Mechanism for securing funding for the UN Convention to Combat Desertification (UNCCD), which is not well publicised. He explained that it is not a "fund" but a catalyst to mobilise multi-channel financing sources for the UNCCD; it emphasises mainstreaming, partnership building and a multiplier effect. Ideally, UNCCD funding should be built into the development plans and budgets of concerned countries, with external inputs being used to leverage other resources. The lack of a specific financial instrument poses special challenges, and fund raising for the convention has not met desires or expectations (the mechanism has only US\$6 million for 2001/2002). It has been suggested that the Global Mechanism could link UNCCD action programmes to combat land degradation with corresponding actions in the forest sector. 


\section{Funding at the national level}

General: There was general agreement that the ideal situation, toward which all efforts should be directed over the long term, is for countries to depend largely on their own resources, while the global economy enables cross-investment among countries and supplementary investments. An FAO overview of national forest funds covering 41 countries and more than 50 funds in both developing and developed countries was presented, along with examples from four countries (Indonesia, Norway, Russia and Vietnam). It was noted that a large number of countries have established such funds to provide some degree of assured continuity in funding for their forest sectors. As one example, Norway's Forest Trust Fund has been highly effective for decades in ensuring SFM among private forest owners, including many small-scale ones.

There is, however, no one model or definition; forest funds typically extend over more than a single government budget cycle, segregating forestry-related revenues and earmarking them for investment in the forest sector. The organisation, income sources, uses and oversight of these entities vary, as do their main areas of focus. Some are designed to promote increased investment opportunities for SFM; others support decentralisation and devolution of forest management; still others focus on promoting the production of environmental goods and services.

Like the proposed Global Forest Fund,

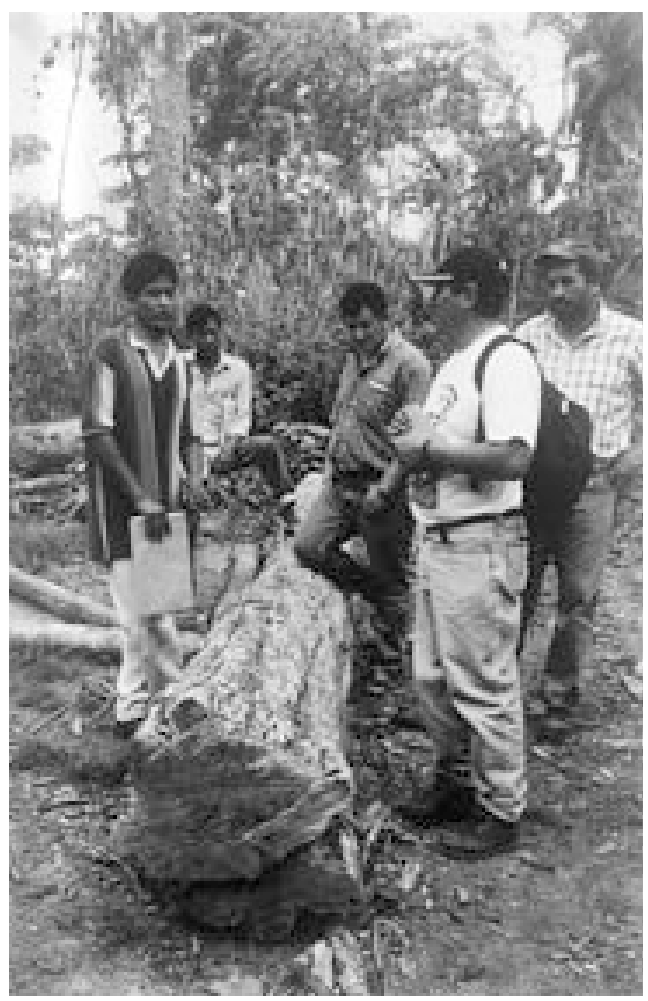
national forest funds are not free from controversy. Proponents argue that such a mechanism can help meet the need for the long-term investment in forest sector operations, shield the forest sector against the fluctuations and unpredictability of national budgets, help stimulate more effective forest management by government agencies and allow for greater oversight of forest spending. Opponents point to weaknesses that include the danger of trapping capital in the forest sector, preventing ideal allocation of government budgets, transmitting misleading economic signals to bureaucrats, weakening the incentive to spend resources wisely and offering opportunities for corruption. 
Participants suggested that national forest funds should be more closely linked with international financing meant to supplement them. The FAO was encouraged to undertake a more comprehensive review of all types of funds, including environmental and social development funds, and examine how they can be used to advance SFM objectives. They also advocated greater sharing of knowledge among countries and regions to enhance capacities.

Indonesia: Haeruman described Indonesia's system of protected areas and its changing management philosophy and new paradigm for national park financing. Contending that Indonesia's greatest need for financing of sustainable forest management is in the area of protected area management, he said the country's present climate of economic, political and legal uncertainty offers opportunities to rethink many ways of doing business.

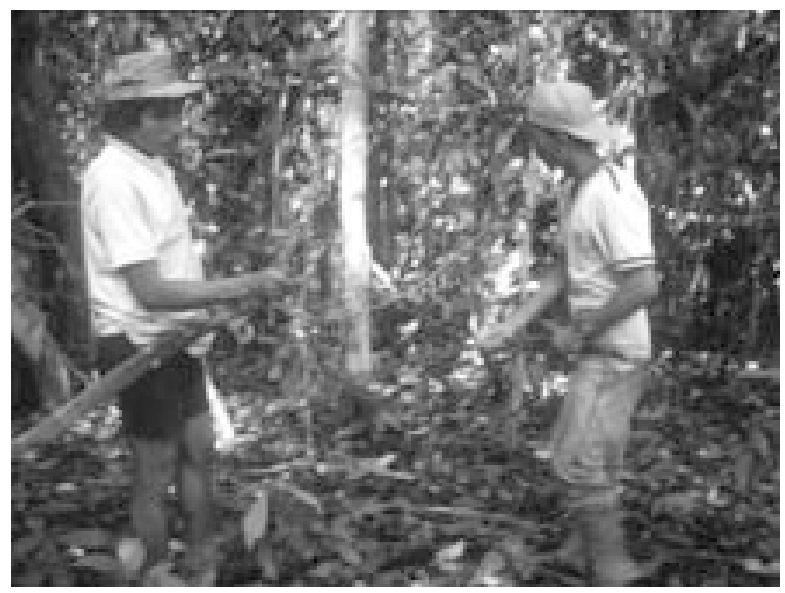
Among other points, he questioned the current basis for allocation of funds to parks and suggested that financing mechanisms should move toward a principle of "the beneficiary pays." Funding would then be based on factors such as how much a given park is worth, the goals for which it is being managed, the costs and benefits associated with it, and to whom they accrue or should accrue. Under such a system, there would no longer be a single, "right" funding stream for all the 39 parks, but combinations of funding sources would be used according to each park's particular attributes.

Norway: istad noted that nearly 90 percent of Norway's forest land is privately owned (76 percent by individuals); there are about 125,000 forest properties in the country, which means the forest authorities have to deal with this many decision makers, each with potentially different objectives for owning and managing their forests. Forestry is seen as an economic activity that should be able to generate competitive income relative to other land uses. The state uses as its instruments for long-term funding the Forest Trust Fund, tax incentives, and cost-share programmes and grants financed by the state budget. The trust fund draws its revenue from private and public forest landowners' mandatory payments of 8 to 25 percent of the gross value of timber sold. A clear regulatory framework, good organisation of the many small forest owners, support and guidance from local government, and strong extension and technical support services have been 
credited with the programme's success. In the future, the purpose of the trust fund may be expanded to include more investment for environmental purposes and to collect money from the private sector in support of forest research and development.

Russia: The picture of the forest sector in Russia is shaped by the many difficulties arising from the country's lengthy transitional situation. Petrov described the sorry state of the country's forest sector following the post-Soviet Union dislocation of all institutions and the economy. Currently, the setting of prices for forest resources and transport by administrative decree is reducing profitability from forests and hampering the possibility of achieving surpluses that could be reinvested. For roundwood exported from Russia, for example, stumpage charges have been set so low that forest owners' economic interests are not covered. In the Soviet days, official transport charges were set so low that distant Siberian forests were economically attractive for exploitation; current charges make that impossible. Petrov advocated replacing the present situation with a combination of rental charges (based on proper economic calculation and negotiation), minimum stumpage rates (dependent on norm-based costs of forest management) and financial flows able to safeguard the interests of all stakeholders. Such changes, he predicted, would increase the capacity to invest in regional sector development and even attract investment because of the prospect of better returns.

Vietnam: Nguyen Xuan Nguyen outlined Vietnam's ambitious reforestation efforts and financing arrangements to fund it. The country is now in its second reforestation programme (targeting achievement of 5 million hectares), for which there are initiatives to promote investment in the forest sector. Vietnam relies on a combination of investment from the state budget (focussing on

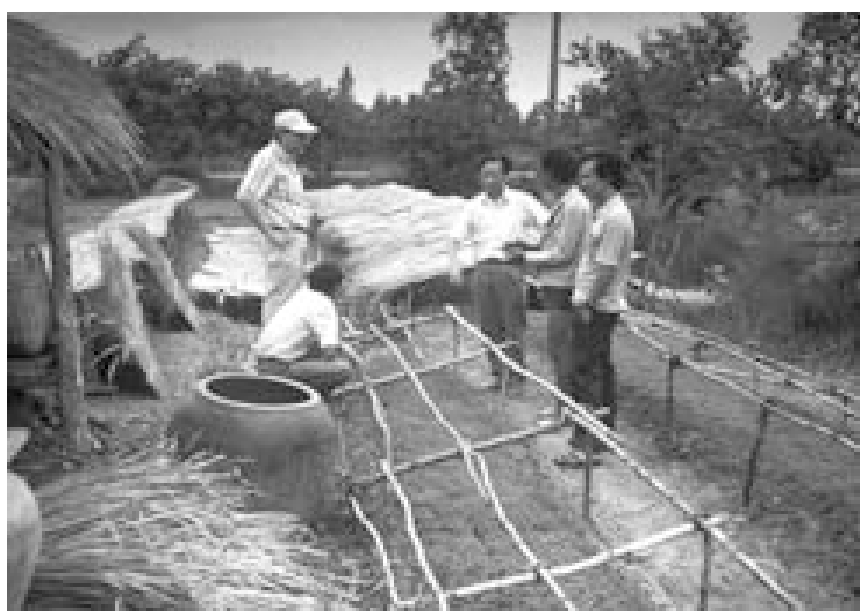
protected and watershed forests), provision of credit for production forest plantations and promotion of investment by forest-affected industries. Lessons from the country's experience included unsatisfactory enabling conditions that provided few incentives for people to participate. The new five-year reforestation programme has problems that include a reluctance by banks to lend to farmers and companies with limited collateral, 
farmers' preference to borrow for activities that provide quicker returns than forestry, and the perceived high cost of loans among farmers. Faced with budget deficits, the Vietnamese Government has sought to mobilise "social investment" as well as funding from domestic sources (such as farming households and private companies). It is also seeking direct foreign investment (private) and official development assistance - efforts that are impeded by a lack of appropriate policies.

\section{Endnotes}

${ }^{1}$ Web site address: www.cifor.cgiar.org/fsfm/index.htm

${ }^{2}$ Some workshop participants referred to official funding of SFM not as a subsidy but as a legitimate "investment" necessary for societal benefits. The belief was that by making such investments, the public sector would lighten the burden of the private sector and prevent it from having to bear the full investment and operational costs when much of the benefit is to be enjoyed by the general public rather than privately by the investors.

${ }^{3}$ The idea of creating an Investment Promotion Entity (IPE) to enhance public and privatesector investments emerged from the IPF/IFF process. In concept, the IPE is at the center of the forestry-financing web, serving as an interface between the public and private sectors and between project developers and potential financiers. In this way, it would promote innovative partnerships between the public and the private sector to fund sustainable forest management (SFM) projects. It would also encourage project developers to apply innovative risk management techniques to SFM projects and to promote SFM and specific opportunities to capital markets.

${ }^{4}$ At the time of the Oslo Workshop, there was optimism that an outcome favourable to forests might emerge from the UNFCCC dialogue. The prospects are not so clear after decisions in early 2001 of some key countries regarding adherence to the Kyoto Protocol. There may be need to reassess the situation.

${ }^{5}$ Markets for an increasing range of hitherto unmarketed or little-marketed goods and services are emerging, evolving or maturing, sometimes even showing the potential to bloom. Governments' interventions will vary by commodity or service, but it is too early to say how long they may have to continue.

${ }^{6}$ A non-legally binding authoritative statement of principles for a global consensus on the management, conservation and sustainable development of all types of forests. Reference document for adapted version is A/CONF 151/6Rev.1 of 13 June 1992. 
${ }^{7}$ Workshop on Financial Mechanisms and Sources of Finance for Sustainable Forestry, 4-7 June 1996, Pretoria, South Africa.

${ }^{8}$ Workshop on Financing of Sustainable Forest Management, 11-13 October 1999, Croydon, United Kingdom.

${ }^{9}$ ECOSOC 1997. Report of the Ad Hoc Intergovernmental Panel on Forests on its Fourth Session. (New York, 11-21 February 1997), E/CN.17/1997/12.

${ }^{10}$ Financial Mechanisms for Sustainable Forestry by Moura Costa et al. 1999. An Assessment of Data on ODA Financial Flows in the Forest Sector by A. Madhvani.1999. Financing Sustainable Forestry: Issues under International Deliberations by M. Joshi 1999. Innovative Forest Financing Options and Issues: Forest Conservation and Management for Climate Change Mitigation by Mark Trexler, 1999.

${ }^{11}$ Referred to elsewhere as the Global Forest Fund (GFF).

${ }^{12}$ The reality, however regrettable, is that people's decisions about whether to cut down the trees in forests are often based on considerations of personal financial profit, and suggesting to them that the true societal economic values of SFM may be comparable to or exceed those of other land uses is often of no avail.

${ }^{13}$ Some sought to avoid use of the word "subsidise" in relation to meeting the incremental costs of SFM.

${ }^{14}$ Price premia are obtainable on a limited scale, but mainstreaming SFM will require progress beyond "boutique" or otherwise relatively minor markets (such as "do-ityourself" outlets) to price premium acceptance by the main end users of forest products, such as in construction, packaging and other uses.

${ }^{15}$ They recognise nevertheless that over time, a greater sense of pragmatism is emerging.

${ }^{16}$ Keipi cautions against assuming that all credit is necessarily good. Experience from Latin America shows that targeted and subsidised credit programmes for forestry, or even for broader operations, such as the Global Agricultural Credit and Integrated Rural Development operations, tend to distort rural financial markets, undermine the viability of many participating financial intermediaries, discourage mobilisation of savings and disproportionately benefit higher income borrowers. By contrast, targeted but nonsubsidised wholesale credit programmes play a role in promoting the expansion and deepening of financial services to underserved producers. 
${ }^{17}$ Raga Castellanos implies that application of strict rules falls inordinately on larger firms, which are already closest to meeting sustainability criteria, making them uncompetitive in relation to smaller firms that escape public scrutiny and so gain unfair advantage.

${ }^{18}$ For example, Petrov notes that in the Russian Federation, stumpage is currently US\$ 0.6 per cubic metre. Even after adding other costs (freight charges are administratively set), Russian prices may be well below the average international market price for timber. This leads to providing greatly cheaper wood (dumping) to the consumer countries of industrialised Western Europe and Japan as well as other far eastern countries such as South Korea and China. This, along with timber from reportedly unsustainable sources in Far East Russia, has adversely affected the international market shares of the tropical exporter countries, in particular Southeast Asian countries including Indonesia and Malaysia. The unpredictable swings in market conditions together with the current trend of oversupply from unsustainable harvesting discourage new investments in the forest sector.

${ }^{19}$ Landrot and Speed report, for example, that because of the ongoing civil wars in the central African region, timber production has plummeted and processing plants as well as other infrastructure have been destroyed. Where the political system is so volatile and unpredictable, it is difficult to expect the private sector to remain engaged in long-term SFM.

${ }^{20}$ Possibly also apply effective sanctions.

${ }^{21}$ In an oral presentation, Christian Mersmann of the UNDP Programme on Forests (PROFOR) reported that PROFOR is moving into a second phase under which finance for SFM will continue to remain a major area of interest. He also emphasised the need to develop national financing strategies for SFM. 


\section{Part II:}

\section{Summaries}

of Papers

Prepared

for the Workshop

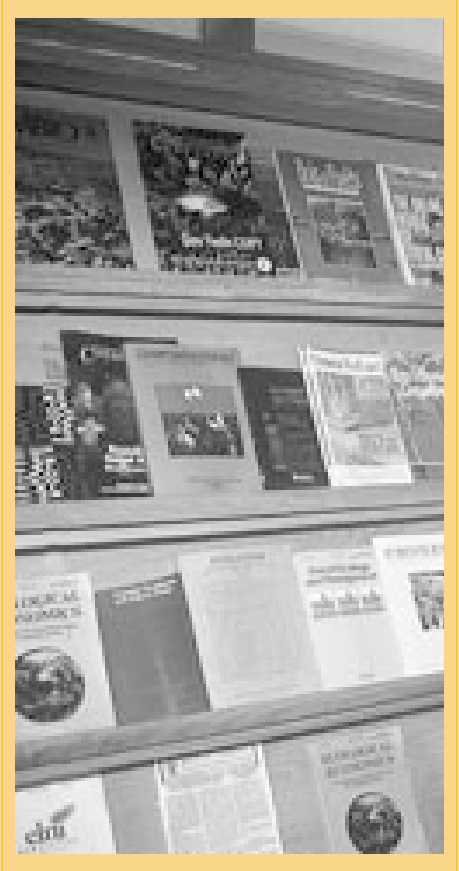




\section{Summaries of Papers for the Workshop}

\section{An Enabling Environment for Investment in SFM}

As explained in the main report, the issue of enabling environment concerns featured in almost all papers, especially those prepared by the private sector, in the national papers, and presentations of the multilateral development banks and funds; placing only these two papers under this heading is largely for convenience of presentation even if somewhat misleading.

\section{Lennart Ljungman and C.T.S. Nair. 2000. Changing Perceptions on Technical Assistance in Support of Sustainable Forest Management. FAO, Rome, Italy}

The ideas communicated by Ljungman came partly from the paper but were complemented by a personal presentation at the Oslo Workshop; this summary draws on both. Ljungman and Nair suggest rethinking the role of technical assistance in development co-operation in the forest sector. They draw lessons from development assistance based on hindsight, ask what has been accomplished, and describe the changing environment for development and its implications for future development assistance. The main thrust of the paper is that financing of forest sector development is constrained more by lack of enabling 
conditions than by lack of funding. It suggests that traditional technical assistance has not improved conditions for better absorption of funding.

To address this, Ljungman and Nair say mobilising national capacities within the framework of national forests programmes is the best way to achieve enabling conditions for SFM. According to the authors, this requires increased attention to generating and sharing knowledge. Another key message is that SFM (and the possibility of achieving it) is determined mainly by what happens outside the sector; thus, enabling conditions are associated with broader reforms in governance, empowerment and freedom of choice, and any action must involve other sectors and other stakeholders.

In the past, development assistance was driven by a perception that low incomes in developing economies prevented the generation of substantial surpluses that could be invested; external support aimed to cover domestic shortfalls in investment. Hence, technical assistance was directed largely at logging and wood processing and related activities, such as resource assessment and inventory, improved accessibility to forests, establishment of industries, development of local skills directly relevant to these activities, research on less known species to enhance their industrial use and others. Where quality of natural forests did not permit industrial development, emphasis was given to establishing large-scale industrial plantations, most often with fast-growing exotics. Feasibility studies of industrial plantations, choice of species, introduction of exotics and related activities (such as improvement in nursery and planting practices, pest and disease management, and growth and yield studies) were the main areas of focus for technical assistance in the 1960s and 1970s.

In many cases, however, the ability to absorb technical assistance and to sustain the initiatives has been unsatisfactory. In several countries, Forestry Departments did not have the resources - technical and financial - to maintain these plantations. With hindsight, it is evident that past approaches to technical assistance had only limited impact, largely because of limited perceptions and focus toward solving problems - or, most often, addressing the symptoms.

\section{Lai Har Chan. 2000. Towards an International Enabling Environment for Investment in Sustainable Forest Management. Kuala Lumpur, Malaysia. ${ }^{22}$}

An enabling environment for investment in the forest sector is almost always considered in a national context. Governments are urged to create policy, legal and institutional frameworks that are friendly to investment and to operations of the private sector. This focus at the national level remains important, but in the current context of globalisation it is no longer sufficient, Har Chan argues. The extra-territorial environment has become 
equally important in influencing decisions about investment in developing countries. At present, the international environment is generally disabling, with problems particularly in three areas: the global trading system, governance and the multilateral system.

The global trading system: Developing countries have for long faced an international trading regime in which prices for their commodities (including forest products) are stagnant or falling. Thus, although logic suggests that in forest-rich countries trade should be an important source of surplus capital to invest in sustainable forest management, this is not so. The international trading system will have to ensure that countries receive equitable and remunerative prices for both the commodities and the environmental services of their forests if these countries are to earn sufficient surpluses needed for reinvestment.

Governance: Governments of developing countries are often encouraged and even pressured into adopting new ideas of governance and high standards of accountability toward their citizens and the international community. At the same time, there are now many large multinational corporations that exercise greater financial power than many individual developing countries. These corporations hold no electoral mandate, have no transparency, owe no accountability to any constituency and do not seek popular participation in their decision making. Yet daily they make decisions that influence the movement of money in regard to investment, trade and speculation, which can make or break entire economies and create or destroy livelihoods. When their actions lead to dislocation of economies, these companies can even contribute to destabilising political systems and provoking chaos. Given their large influence and power, large transnational corporations heavily influence perceptions that many developing countries pose a high risk for investment, including for sustainable forest management.

The multilateral system: The past decade has witnessed a greater frequency of crisisand-rescue interventions by the World Bank and the International Monetary Fund in developing countries in an effort to restore stability. In many developing countries, the World Bank is now seen not as an institution to aid development but as a banker in a three-piece suit, with the bottom line already set. It is seen as focused not on development but on financial performance of projects, and appears unsympathetic to the livelihood implications of structural adjustments it imposes, many of which lead to severe economic contraction.

With regard to the International Monetary Fund, many developing countries have compared the institution to a doctor who prescribes the same pill for all patients, regardless of their maladies. Lai Har Chan observes that the IMF advises countries in crisis to adopt currency devaluation, budgetary reductions, increased taxes, economic liberalisation and removal of subsidies, regardless of the country's circumstances. Under even normal conditions, currency devaluation can lead to a rapid outflow of funds; in crisis, such 
devaluation can lead to economic haemorrhaging as huge amounts of funds are transferred out of the country in panic. Reducing public budgets will contract the economy even further at a time when the private sector is contracting. Increased taxes reduce individuals' incomes and consumption, while also reducing funds from corporations that could be used to expand private investment needed to turn the economy around. Pressuring such countries to liberalise their economies by forcing them to open up to foreign participation has led to "fire sales" of domestic corporations and banks at cheap prices. Furthermore, the IMF's penchant for pressuring countries in crisis to remove subsidies, including subsidies on essential goods, can lead to social unrest as prices escalate. Industries exposed to such conditions can quickly lose their competitiveness, and the capacity of many sectors, including the forest sector, to invest in sustainable development is severely curtailed.

\section{Private Sector Financing of Sustainable Forest Management}

\section{Hans Gregersen and A. Contreras-Hermosilla. 2001. Investing in the Future: The Private Sector and Sustainable Forest Management. U.S.A.}

In the lead paper on the private sector and sustainable forest management, Gregersen and Contreras address a number of questions related to expanded private investment in SFM: What is the nature and magnitude of private investment in forest management and utilisation? What is SFM, and where and why is expanded private investment needed in it in the future? What constraints - in terms of market, policy and other institutional failures - need to be overcome, and what are the most appropriate policy mechanisms to do so?

It is important to distinguish different types of private investment and investors, which may consist of: a) foreign investment by large multinationals and investment by local companies in local situations; b) highly regulated companies, often from developed countries, and investor companies subject to much less regulation and having less concern for their international public image; c) direct investment and portfolio investment; d) individual private investment (such as in SFM-related conservation activities by philanthropists and community investment in SFM); and e) corporate and joint investment, such as through public-private partnerships. The authors believe that the challenge of channelling more private resources into SFM will be met only by focusing on wider combinations of private and public capital flows and taking a landscape or macro view of SFM requirements. 
To the key question "What are the constraints?" the answer is, simply, that SFM is not as profitable for private investors as unsustainable forest management. Often, the costs associated with producing market-based outputs through SFM (including the transactions costs for certification) are higher than for the same outputs from unsustainable forest management, but compensation in the marketplace resulting from consumer demand is not yet high enough to make the additional costs attractive to most producers voluntarily. The authors propose ways the constraints could be overcome to induce more private investment. They give considerable attention to policy actions that they say governments and civil society should consider to create a favourable enabling environment for private investment in SFM. In broad terms, these consist of two areas of focus: first, creating a set of laws and regulatory mechanisms that provide a positive investment framework in an environment that protects society's interests while also being attractive to private investors; and second, providing market incentives for private firms and individuals to invest in SFM rather than in unsustainable forest management.

The bottom line is that the levels of profitability associated with SFM must be high enough and the risks low enough to attract investment; whileas, for unsustainable forest management, profitability should be reduced and risks increased to discourage it. Policies and actions to address this include eliminating subsidies and other preferential treatment to sectors that compete for land with the forest sector, establishing firm monitoring and control of illegal operations, combating opportunities for corruption, avoiding the development of transportation infrastructure near forests of high value (including environmental value) and avoiding negative political interference in administration.

\section{Jean Jacques Landrot and Steven Speed. 2000. Private-Sector Investment in Sustainable Forest Management in Humid Tropical Africa. Inter-African Forest Industries Association, Abidjan and Paris}

Landrot and Speed present a concise but wide-ranging picture of private-sector investment in SFM in humid tropical Africa. They outline its history and importance in the region, constraints to greater investment in SFM and ways of increasing such investment. They make the point that the private sector has started to contribute to sustainable management practices and is willing to continue doing so, but needs help, especially inasmuch as society as a whole derives many of the benefits of SFM.

The private sector is diverse in form and in its ability to contribute to or to practice SFM. Africa has large European firms with a global turnover of US\$100 million to $\$ 500$ million per year. Asia has multinational groups, generally of Malaysian or Chinese origin. There are also medium-sized businesses of diverse ownership, which often lack technology and financial means, and small national businesses, often of family or village scale and 
generally informal. For this last category of forest concessions, their small size, lack of technology and financial means do not enable them to pursue any other strategy than operating from day to day. Finally, in Africa, there are also joint ventures built by Africans with political connections but relying on the expertise of expatriates, which are bent on generating a maximum amount of money in the shortest possible time.

The constraints to private-sector financing of SFM in humid tropical Africa are varied. Overall, these constraints include: a) poorly defined concession and ownership rights; b) institutional requirements (many countries have inadequate roads, bridges, schools and other infrastructure, and expect forest companies to provide these; c) the poor commitment of States toward the forest sector, manifested in a failure to include forestry in national development plans; d) weak and unstable government and rampant corruption; e) lack of markets for many of the benefits derived from SFM (including environmental services and "public goods" functions), leaving investors to shoulder the costs; and f) difficulty in achieving acceptable levels of profitability of SFM in the relatively short periods in which private forestry companies operate. Political instability is also often a problem.

Landrot and Speed identify opportunities for increasing private SFM investment in Africa. These initiatives are in areas of achieving greater stability and reliability in the rules and conditions governing investment (plans, tax regimes, land use demarcation, legislation favouring adequate returns to investment, matching industrial with forest capacity, training and research); donor and international support (debt relief, public funding for "public goods" aspects of SFM, international funding, harmonised donor policies, actions and funding flows); actions at the business level (investment insurance, market development and marketing, co-operation between large and small enterprises, assurance of profitability for rotations after the first); and actions by international NGOs (greater pragmatism and realism in pressing for compliance with concerns about biodiversity, ethnic minorities, balance between conservation and production, application of western standards outside their context, not exaggerating the contribution of logging to forest loss compared to other causes).

\section{Barney S.T. Chan. 2000. The Private Sector and Sustainable Forest Management - Southeast Asian Perspective. Sarawak Timber Association, Malaysia}

The main message of the paper by Chan is that sustainable forest management has too many benefits that are not enjoyed by the private sector alone for it to be regarded solely or mainly the responsibility of the private sector. Chan sees the public sector as a proxy for broader society; he argues that because the benefits of SFM go well beyond the confines of the "private sector", the financial burdens of SFM should also be shared by all the (societal) recipients of those benefits - through public-sector investment in return 
for benefits of the forests that do not produce direct profits for the private sector. He argues that if the public sector fails to be a partner in implementing SFM,(and its role is critical), private investors will not have an interest in investing in SFM.

As an indication of how much SFM concerns fall outside the private sector's direct interest and ability to address, Chan reports that of the seven criteria in the International Tropical Timber Organisation's criteria and indicators for sustainable forest management, only three have direct impact and one indirect impact on private business decisions. He suggests that the following four areas require government action or should be handled primarily by governments: enabling conditions for SFM, security of forest resources, forest ecosystem health and condition, and biological diversity.

A second main point is that markets offer no encouragement to SFM. They pay no price premium and show no loyalty to products from sustainable sources. Citing as an example the large Japanese market for logs from Sarawak, he reports that considerable improvements in forest management in Sarawak following an ITTO mission were not rewarded by increased demand in the key Japanese market. Instead, Japanese trade data show "a steady decline in log exports from Sarawak to Japan, with corresponding increase in log exports from Russia to Japan. The increased SFM efforts by loggers in Sarawak were neither rewarded by higher export volumes nor better prices; rather, the Japanese switched to cheaper Russian logs in order to maintain their profitability."

A third problem Chan discusses is apparent discrimination in international markets (or selective application of standards, with negative impact on demand) against tropical timber. He mentions zealous and enthusiastic NGOs boycotts and demonstrations against the use of tropical timber and timber products in consumer countries, resulting in many consumers turning against these products. He suggests that profitable operation of industry in producer countries is becoming increasingly difficult, and without profits there can be no investment. Finally, Chan highlights developing countries' weak efforts in moving toward plantations to supply forest products.

For the private sector to better influence international image and policies, Chan recommends greater engagement with international policy processes, specifically with the U.N. Forum on Forests (UNFF), believing that "the UNFF process must recognise that the private sector is a major stakeholder in SFM and must, accordingly, be very actively engaged in the due process." He offers concrete proposals with regard to developing suitable market instruments, establishing a new fund for establishing tree plantations, increasing the amount of training in developing countries, and conducting more research and development, including by the private sector. 


\section{Ivan Tomaselli. 2000. The Private Sector and Sustainable Forest Management - South America Perspective. STCP, Brazil}

Tomaselli paints a broad-brush picture of private-sector engagement in the forest sector in South America, along with more in-depth profiles of emerging situations in selected countries. He summarises the significance of forests in South America; presents the existing funding mechanisms for forests (describing the bias in favour of plantation investments); highlights the main constraints in financing of SFM (noting how natural forests have not so far proved attractive to private investors); and outlines prospects for the future and possible solutions to major issues. He stresses the need for appropriate, stable and transparent regulations, economic and political stability, and guarantee of access to forest resources and markets.

Tomaselli's key message is this: "The market is, in the end, the main source of funds to finance SFM." He argues that "if the private sector has to increase its contribution to financing SFM, governments and also other stakeholders need to create the necessary environment for investment." Tomaselli also discusses the poor environment for investment generally; the rapid increase in legislation and regulation and consequent increase in costs for investors (a trend apparently worsened by decentralisation); the tendency to seek immediate fulfilment of SFM standards without accepting step-wise improvement and without incentives to encourage adoption of best practice; the tendency to elaborate on sustainability standards and their associated certification requirements in ways that raise costs; the failure of markets to reward SFM practice. Tomaselli is concerned that production and markets are based on too narrow a range of species to absorb the higher costs of SFM.

Regarding plantations, Tomaselli considers this area a model of success in using fiscal incentives to promote forest expansion, and notes that there are no known comparable incentives to promote sustainable management of natural forests. He suggests that incentives are needed to not only catalyse the adoption of SFM but also to enhance performance and sustain the practice of SFM.

Tomaselli views with concern cost-raising bureaucratic developments in most Latin American countries under which forest regulations are growing with the aim of achieving SFM. This is happening in an environment in which there is already low managerial capability of local governments. Decentralisation is greatly increasing the bureaucracy, creating overlapping structures and legislation and adding new costs to forest management. With certification growing in importance at a time when governments are not trusted to manage it, new institutions are being created, further adding to costs. These costs are, at the end of the process, transferred to the production chain, with the burden falling on 
operations to improve forest practices at field level. What this means is that decentralisation policies adopted by many countries in the region are not working as expected to benefit forests. Tomaselli cites Bolivia as an example where well intentioned legal reform favouring SFM and administrative decentralisation have led to severe over-regulation, inefficiency, high costs, loss of markets and industry decline, all within a short time.

\section{Fernando Raga Castellanos. 2000. The Private Sector and Sustainable Forest Management-A Private Perspective from South America's Southern Cone. Chile}

Raga Castellanos describes different stakeholder visions of sustainability and the impact on private-sector investment in SFM in South America's Southern Cone. He cites the main incentives and deterrents as well as environmental challenges and opportunities for SFM in the Southern Cone, concluding with suggestions for moving further toward SFM. First he presents different perceptions of SFM. One, "microscopic sustainability" seemingly preferred by most NGOs and some European countries - requires that each forest stand meet all the sustainability requirements and cover the multiple forest functions demanded by society. The second view, "macroscopic sustainability," argues for sustainability to be judged and practised at a larger landscape level; it accepts that a variety of specialised forests, each focused on fulfilling distinctive roles, can, when taken together, meet society's multiple demands. In this latter viewpoint, plantations, secondary forests, primary forests and other kinds of forests all play their part in contributing to SFM - an approach the private sector sees as more feasible and more socially and economically efficient. So far, the private sector has focused mainly on plantations, a component orf "macroscopic sustainability."

Raga Castellanos believes the pressure to require forest operators to achieve "ideal SFM," while failing to recognise incremental progress in that direction, has led many owners and operators to view improvements as a burden and has discouraged them from making positive changes. He notes that private operators find themselves expected to produce various public goods (such as biodiversity and landscape conservation) at no cost to society but at private cost to themselves. Thus, with timber sales as their only source of income, private investors are being asked to bear the burden of society's broader gain something the private sector cannot do and yet remain profitable and competitive. A compromise approach he suggests is for the private sector to adopt and pay privately for the basic requirements toward achieving "sound practices," and for society, if it demands full manifestation of SFM, to contribute to financing the private-sector production of "public goods" by means of subsidies. 
Other problem areas for SFM investment that Raga Castellanos highlights are undefined property rights and ever changing "rules of the game"; lack of acknowledgement by some NGOs and the public of progress toward "sound practices" 23 ; unfair, unreasonable and superfluous costs and restrictions ${ }^{24}$; and the difficulty of promoting "sound practices" among small and medium-sized operators within an informal economy ${ }^{25}$. Raga Castellanos implies that application of strict rules falls inordinately on larger firms that are already closest to meeting sustainability criteria, thereby making them uncompetitive with smaller firms that escape public scrutiny and so gain unfair advantage.

Ways he cites to promote SFM include the creation of an investment-friendly climate (with, among other things, clear and consistent rules on property rights), stable rules for SFM and reasonable costs, State intervention in setting prices for externalities provided as benefits to other sectors, contributing to the cost of producing public goods when so suggested by the ratio of private cost to profitability, simple and easy to enforce laws, appropriate incentives and an effective certification system.

Most attention in regard to SFM, Raga Castellanos observes, should be given to small and medium-sized owners (which he says are responsible for a large part of current forest-related problems). He argues that these groups should be regulated through feasible and realistic rules and should be strongly encouraged to join the formal economy if forest practices are to be improved.

\section{Peter Mertz. 2000. Investing in Sustainable Forestry. UBS Timber Investors, U.S.A.}

In a presentation that focused on case studies, Mertz outlined the magnitude of investments through timber management companies, the spread of investments between developed and developing countries, the exclusive interest of UBS Investors in plantations (the advantages of which he outlined) and factors considered in assessing investment opportunities in any country.

Of greatest interest were the investment criteria considered in prospective investments, which include relative risk (such as political stability, the ethnical and legal framework and financial stability); land tenure rights; government interest in and support for forestry (as indicated by tax structures, the legal and regulatory environment and whether an investment is considered a "project of national interest"); global competitiveness (such as access to world markets, state of the infrastructure and the availability of a quality workforce). 


\section{David Brand. 2000. Mechanisms to Encourage Private Capital Investment in the Environmental Services of Forests. Hancock Natural Resources Group, Australia}

Brand's paper, which draws heavily on experiences in Australia, describes the nature of international investment in forests and the significance of the Kyoto Protocol to the forest sector (as perceived before March 2001 policy decisions against the Kyoto Protocol by key countries). He describes policy developments since the establishment of the Kyoto Protocol, outlines potential opportunities for using carbon offset investments to fund sustainable forest management, suggests other environmental markets for forests and proposes actions needed to make potential opportunities a reality. Brand sees a growing awareness that the environmental and ecological services of forests may be as valuable as or more valuable than those related to timber, energy and harvested forest products. Many of the newly regarded values address management of forests to combat three of the great environmental challenges of the $21^{\text {st }}$ century: climate change, loss of biodiversity, and the degradation of land and water resources.

The broadening of private forest investment opportunities to include conservation and environmental and ecological services could make sustainable forest management more financially rewarding than unsustainable practices and result in more diversified revenue flows. Currently, most investment is through timber investment management organisations, and the criteria they use to judge investments can be seen as a good benchmark of the requirements of global capital.

Certification can aid investment by reassuring investors in areas of concern such as:

Risk and uncertainty vs. return (uncertainty is particularly acute for international investors in cases where local firsthand knowledge is lacking). In countries without well-developed institutions, markets and technology, investors require high rates of return and shorter term, lockedin cash flows. This helps explains why much investment in developing countries today is short-term financing for timber harvesting;

Investment structures, liquidity and investment periods: Most institutional investors in forestry are willing to accept an investment term of a decade or more, but liquidity is an important element of such investment. Complex regulations on foreign ownership or lengthy approval procedures for changes in title or business ownership are an impediment to liquidity.

Cash flow and time to cash flow: Buying existing mature forests should allow immediate access to cash flow from timber harvesting. 
Land acquisition: Investors generally seek secure ownership of resources, usually via a logging concession or lease. For long-term management, however, investors often require land ownership or legal title to the forest being managed.

Issues of reputation and ethics: Professional investment management organisations tend to avoid activities that could draw negative reaction from key interest groups. This caution is magnified in the forest sector, especially in relation to the harvesting of primary forests, because of issues such as concerns over the rights of indigenous peoples.

At the time when Brand's paper was written, climate change was an attractive pioneering market for forestry investments, and many governments were forging ahead with legislation and regulations to begin the process of reducing net greenhouse gas emissions; pilot trials of emissions trading were being implemented in a number of countries. Many still believe a carbon credit market would increase the value of maintaining and sustainably managing forests, thus offering a viable alternative to unsustainable agriculture.

With regard to other environmental markets, forests have potential to address dryland salinity (for which governments could encourage private capital by establishing a salinity credit trading scheme); biodiversity conservation (the need is to define a method of simply calculating some unit of biodiversity that will work across a wide range of conditions and might form the basis of a tradable unit); and more traditional opportunities, such as tourism. The incomes from these benefits can be additive, thereby improving returns to the investor and diversifying revenue flows.

Brand expects the growth of services-driven investment to be "slow and evolutionary." He offers specific recommendations on how to encourage the creation of significant services markets in relation to areas such as creation of property rights and linking investment to key conventions on biodiversity, climate change and desertification.

\section{M.K. Muthoo. 2000. Certification and Sustainable Forest Management. Forest Stewardship Council, Mexico}

Muthoo outlines the role of certification in promoting environmentally, socially and economically appropriate forest management. He notes that independent forest management certification is a recent phenomenon in forestry, although well established in many other industries. The assurance of conformity with a set of agreed standards has the potential to encourage investment if there is a meaningful advantage, especially a market advantage. This linkage with market incentives could make certification a powerful market-based tool for promoting sustainability and good forest management. While 
acknowledging that certification usually increases management costs, which are not always recovered in product prices, the author argues that some of the benefits of certification are in the form of perceived ethical, environmental and social responsibility, although in the medium to long term there should also be a rise in financial profitability.

Some of the criticism surrounding the demand for sustainability is that it is idealistic. Muthoo says that if certification standards are too demanding, targeted to the "boutique" end of the trade, the approach will lose its capability of promoting real change. Equally, however, he believes it will fail if too undemanding and "business as usual" in approach, aiming to satisfy the "lowest common denominator." While certification is meant to be open and impartial, it is not always easy to create a level playing field; it is easier for large enterprises to adopt than for small ones, for example. To make it more accessible to smaller enterprises, the Forest Stewardship Council has developed systems for group certification and related approaches, although this has been limited.

Another challenge is the large gap between what is happening today in tropical forests and what is required for certification. Efforts underway are directed at developing simple, affordable methods for recognising forest managers who are committed to good management and are making clear and measurable progress toward certification. The paper cites the need for international investment to promote and strengthen national capacity and efforts in developing countries facing stringent budgetary constraints, including the need for assistance to countries in transition, including those of Eastern and Central Europe, Russia, Central Asia and Caucasus.

\section{Mike Goldbatt. 2000. The Private Sector and Sustainable Forest Management - Perspective from Southern Africa. South Africa}

In a paper that focuses on plantations in South Africa, Goldblatt describes the success of certification as a measure to support SFM. A private-sector motivation for certification has been the perception that certification may change from being a means of distinguishing a product to a condition of entry into some markets. Goldblatt reports that certification does not appear to have aided market growth, but says it has probably been essential to retain existing markets. He does not address the impact of certification on investment and willingness to invest.

Goldblatt calls attention to challenges that remain, such as social issues related to SFM and the relative position of small and large-scale commercial operations. The direct costs of certification itself appear to be modest and are likely to decrease further in the future as more local certifiers compete with international certification firms; it is the initial changing of management practices in order to qualify for certification that is costly. 
However, for small growers even at present levels, the costs of certification are likely to be prohibitive and are therefore an obstacle to their certification. Some small growers have become certified to maintain particular markets, but they are in the minority. Cooperative schemes in which a number of small farmers share the fixed costs of certification have emerged.

\title{
Investment Promotion Entity (IPE) as a Potential Means for Promoting SFM
}

\author{
Mafa E. Chipeta and Mahendra Joshi. 2000. Feasibility and Operationalisation \\ of an Investment Promotion Entity (IPE) for Sustainable Forest Management - \\ Highlights from the Main Papers. CIFOR, Bogor, Indonesia, and UNFF \\ Secretariat, New York, U.S.A.
}

This synthesis paper was prepared based on key findings and issues of two separate papers: Feasibility and Operationalisation of an Investment Promotion Entity (IPE) for Sustainable Forest Management (by Moura Costa, Fretz and Kohn) and Feasibility and Operationalisation of an Investment Promotion Entity (IPE) for Sustainable Forest Management - Demand and Supply Aspects (by Salmi, Oksanen and Simula). The highlighted issues included the following:

Should the international community proceed with the IPE idea, and if so, what steps are needed to promote partnerships and other forms of cooperation with private parties?

Given that private-sector fund managers are likely to invest only in developing countries with lowest risk and the most stable investment environments, how can IPE work to ensure that the benefits reach many of the poorest countries in greatest need of investment, and how can the public international sector assist in this regard?

At the currently suggested scale (less than the total current annual official development assistance), the IPE may not effectively begin to satisfy the level of need. How can the IPE be made to raise new and additional funds rather than diverting existing assistance, and how can the volume of investments made through this new proposed instrument be increased? Is there support for the idea of establishing the IPE at a global level, with a possibility of establishing regionally oriented IPEs later on, and for hosting regional IPEs at regional multilateral development banks? 
Pedro Moura-Costa, Lionel Fretz and Gerald Kohn. 2000. Assessing the Feasibility and Operationalisation of an Investment Promotion Entity (IPE) for Sustainable Forest Management. Ecosecurities, Oxford, U.K.

Moura Costa et al. provide an overall picture of the way ahead for the IPE in support of sustainable forest management. The paper conveys optimism about the prospect of having willing investors (both private and public). It outlines the likely supply and demand for SFM investments via the IPE, describes the role, nature and structure of the IPE, steps for establishing the mechanism, and its estimated growth path and financial viability.

The paper notes that according to trends, official development assistance is declining in absolute terms and as a percentage of financial flows to developing countries. The potential pool of funding from the private sector, on the other hand, is much larger. Attracting American and European institutional investment into SFM in developing countries has been a problem, as western investors have shown a strong preference for a few low-risk countries where they invest in plantations (seen as posing lower risk) and timberland investment. Emerging Asian multinationals, in contrast, tend to be bolder in their investments. Moura Costa et al conclude that substantial financial resources are available for projects that meet the risk/return profiles that the market demands.

The IPE is seen mainly as a means of investment packaging and structuring of finance, information support and facilitation of access to risk-mitigation services. The authors propose a governance and corporate structure and explore its financial viability, observing that after an initial public-funding launch with total capital requirements of about US\$ 4 million to 5 million, the IPE could be financially viable. The IPE would begin at a small scale, focussing on familiar kind of projects and concentrating on only a few countries, as a strategy to achieve early success and thereby attract new business. No "replenishment" of public funds would be needed, although the public sector would pay "user fees" like other clients if they sponsor projects through the IPE. Governance would be controlled by private-sector investors, not dominated by donors or public-sector agents. Thus, the IPE should aim to sell a controlling stake of its shares to private-sector investors. Pros and cons for a number of institutional options are explored, but a single free standing new structure is preferred, in interaction with existing private-sector and public bodies. A regionalised set of investment promotion entities is seen as offering some advantages, but these are suggested for a later phase.

The IPE corporate structure would consist of three distinct but interlinked functions: an investment-banking arm (highly commercial), an information unit and a risk-management unit. The IPE would avoid duplication with other international mechanisms and instead would draw upon other instruments where they could help resolve clear market and institutional failures beyond the IPE's scope. 
Jyrki Salmi, Tapani Oksanen and Markku Simula. 2000. Assessing the Feasibility and Operationalisation of an Investment Promotion Entity (IPE) for Sustainable Forest Management: Demand and Supply Aspects. Indufor Oy, Helsinki, Finland

The paper by Salmi et al. complements that of Moura Costa et al. and focuses on demand and supply aspects of SFM investment. The authors suggest that the IPE's raison de être is to facilitate and broker SFM investment deals between different financing sources and the managers and owners of forest land in developing countries and in countries in transition.

Salmi et al. review recent international developments in relation to forest sector funding. They note that the clients of IPE are likely to range from large private landowners, forest management companies and institutional investors to public-sector entities. To achieve a "fast track" record on sizeable deals, they suggest it would be best to target large and medium-scale private sectors, which tend to operate in a relatively simple business environment. They estimate that the volume of demand for SFM investments in developing countries could reach US\$ 15 billion per year, ${ }^{26}$ with the IPE's share reaching as much as a few hundred million dollars in five years (a combination of investment from both the private and public sectors).

The authors arrive at three main conclusions: a) there is demand for financing of SFM in developing countries and countries in transition that is not currently being met, (b) there is a potential supply of considerable SFM financing from various sources, but current organisations and mechanisms are not able to bridge the gap as the IPE might be able to do in drawing on its complementary role and potential comparative advantages, and c) a full-fledged feasibility study of the IPE should be done to enable informed decisions by interested parties.

\section{Global Forest Fund and Related Mechanisms}

Discussions of the Global Forest Fund were accompanied at the Oslo Workshop by presentations on proposals for consortium funding of SFM, although such an approach is not seen as a substitute for the proposed GFF. Better mobilisation of international funding through consortium approaches would involve combinations of public and private financing organised directly among concerned players or through the Investment Promotion Entity or a similar mechanism. 
Mahendra Joshi and Mafa E. Chipeta. 2000. The Global Forest Fund - From Rio to IFF4: What Issues Remain? CIFOR, Bogor, Indonesia, and UNFF Secretariat, New York, U.S.A.

Joshi and Chipeta begin by reviewing the ongoing international forest policy deliberations on finance issues, and specifically a proposal to establish an international forest fund (often referred to as a Global Forest Fund). They outline the dialogue leading up to the issues discussed in the Oslo Workshop. The paper includes annexes from the reports of the final sessions of the Intergovernmental Panel on Forests (IPF) and the Intergovernmental Forum on Forests (IFF). Justifications given for a Global Forest Fund (GFF) include the need to pay for international public goods produced by forests and for the cost of making the transition to sustainable forest management practices. Opponents of the GFF advocate better use of the existing funds before calling for a new mechanism. The paper provides a basis for further discussion by the Oslo Workshop of issues left unresolved.

\section{Barin Ganguli. 2000. Global Forest Funding - Exploring Consortium Financing of Sustainable Forest Management. CIFOR, Bogor, Indonesia}

In his paper on consortium funding, Ganguli points out that the approach is not new but has already been "mainstreamed" by the private sector to fund major endeavours. Describing the approach as suitable for national and external funding, he focuses on international consortia involving minimal "service units" for consultative and clearinghouse functions. As background, Ganguli conducted extensive interviews and solicited information from the donor and multilateral aid community.

The benefits of a consortium, Ganguli notes in his paper, include the following: a) it can complement declining public aid with private-sector funding, thus providing new and additional funds and expanding overall SFM investment; b) it can broaden the range of recipient countries; c) it can combine environment-oriented official development assistance with production-oriented commercial private money and socially oriented financing from benevolent foundations, thereby helping the forest sector to meet the multiple benefits ${ }^{27}$ expected from SFM; and d) it can improve co-ordination of international funding. And the possible disadvantages cited: greater complexity of programmes, enhancing the potential for donors to "gang up" on poor countries, confusing operational procedures and a possible movement toward "least common denominator" compromises.

From the information he collected, Ganguli found that donor countries seemed to generally like the idea of consortium-based funding, although they emphasise the need for it to be 
harmonised with and not duplicate other measures. Some multilateral development banks viewed the approach positively, while in the private sector, consulting firms seemed especially enthusiastic. There was more support for ex post arrangements (such as convening consortia for individual programmes or projects) than for open-ended permanent associations. There was also wide agreement on the need for broad inclusiveness of partnerships (combining financial institutions, other donors and the corporate private sector).

Like other authors, Ganguli notes that, the perceived advantages of consortia notwithstanding, inadequate mechanisms for delivering funding are not the most important constraint to financing of SFM. According to the multilateral and bilateral donors he contacted, the main deterrents are a low level of priority toward the forest sector among developing countries and donors alike, and the private sector's fear of being burdened with additional, unrecoverable costs in managing forests for public goods benefits.

\section{Frank S. Kufakwandi. 2000. Consortium Funding for Sustainable Forest Management: African Perspectives and Priorities. African Development Bank, Abidjan, Ivory Coast.}

Kufakwandi discusses forest sector development in Africa in the context of the need to address other pressing problems facing the continent, especially pervasive poverty and high levels of national indebtedness. He writes: "Many African countries, in their dayto-day struggle to satisfy the most basic needs of their populations, are unable to take a long-term view, which is the time frame required for the successful implementation of sustainable forestry management programmes."

He agrees with many of the other authors that to mobilise investment in the forest sector, it will be necessary to address problems such as inadequate political will and commitment, the weakness or inappropriateness of institutions and policies, poor adaptation of funding mechanisms to the long-term nature of forestry, the failure of the international community to translate its concern for forest conservation and biodiversity into financial support, budget pressures that are often made worse under structural adjustment programmes, and poor co-ordination among funding sources, including donors.

Kufakwandi stresses the importance of concessional external financial resources "to support non-commercial forestry activities, provide technical assistance and serve to catalyse development." Reviewing the performance of forestry investments to date, he finds them inadequate because, among other things, they have atomised into compartmentalised projects, are donor-driven, not committed to the long term and are usually narrowly focused on wood production. Moreover, they tend to ignore socioeconomic issues and do not complement other private and official investments. 
These and other problems, Kufakwandi asserts, could be resolved in part by a consortium approach. Besides building effective partnerships for the promotion of SFM practices, consortium arrangements may increase co-ordination and long-term commitment towards forest sector development among donors, the private sector and governments. He sees the following requirements as essential for consortia to operate successfully: political commitment and support at the international and national levels, a small secretariat to administer and co-ordinate activities, a full representative Board of Trustees and a matching of donor resources by national governments' allocation of budget funds for the sector's development. In addition, Kufakwandi says, there should be broad agreement between donors and national governments as to which activities are to be supported by the public sector and which by the private sector. Finally, he calls for regional development banks to take the lead role in co-ordinating and channelling resources for SFM within the consortia.

\section{Other Means of Increasing Financial Resources from All Sources}

In his lead paper on international mechanisms for sustainable forest management, Douglas drew on the experiences — both good and bad — of the World Bank in the sector. Other papers in this area came from representatives of the Inter-American Development Bank, the Global Environment Facility and Global Mechanism for the U.N. Convention to Combat Desertification. All the authors sought to communicate not only the status quo but also how things could be improved for more effective SFM investment in the future. National funding was explored alongside an international overview by FAO covering 41 countries and more than 50 funds in both developing and developed countries. Examples from four countries were presented.

\section{International Funding Mechanisms}

\section{Jim Douglas. 2000. Financing Sustainable Forest Management: Doing More With (Probably) Less. World Bank, Washington, D.C., U.S.A.}

Describing sustainable forest management as not an end in and of itself but "a means to an end," Douglas asks: "What is that end ... [a]nd, is sustainable forest management the best means, or even a good means, of attaining it?" Noting that sustainable forest management is often viewed (in a favourable light) in comparison with unsustainable forest management or with displacement of forests by other land uses (which are often 
unsustainable), he suggests that the loss of actual forest should not be the primary concern but loss of "a suite of environmental and social values that forest is believed to hold but which are undervalued in the normal business of land-use decision making and commercial forest production." While SFM may be one way to address such concern, it is not the only option, he notes, and as a strategy for helping to retain forest cover it can be marginal.

Douglas raises other key questions about SFM and its role and effectiveness, including why international funds should be used to finance forests and, if so, what the focus should be and what mechanisms are best to carry it out. He contends, among other things, that the international community should finance forests because from an environmental economics viewpoint, degradation or loss of forests (often caused for private gain) imposes damages on broader society, including the loss of biological resources, alteration of hydrological flows and disturbance of the global climate. Given that the effects of forest loss are often borne by people - many of them among the poorest people in the world - who do not benefit from the forest exploitation, and that their governments lack the resources to respond, there is a strong case for international funding, according to Douglas. He argues for using financial flows to change the behaviour of those that use and damage the forest most so that more socially desirable outcomes are achieved. Another important objective should be to directly improve the quality of life for forest-dependent poor people, in line with the poverty alleviation mission of many aid institutions.

Douglas says the focus of international funding should not necessarily be on regulating logging in natural forests or the most commercially valuable forests. Priorities also should include preventing complete loss of forest cover by other land use changes, such as conversion to mining or cropping - suggesting the need for a cross-sectoral approach.

Drawing on the World Bank's experience, Douglas describes a variety of funding mechanisms that have been used. These include: a) financing regulations (for regulatory infrastructure and mechanisms to enforce laws, taxes and environmental service agreements); b) environmental services payment systems; c) systems of tradable development rights (as a way to compensate those who bear the cost of conservation); d) disincentive systems (such as the imposition of taxes or fines); and e) financing innovations (which encourage "markets" for measures and practices that foster better forest management).

Regarding future improvements, Douglas refers to lessons from the World Bank's 1991 Forest Strategy and its 1993 Forest Policy, including the "chilling effect" of a do-noharm approach that he says has been practised so far. He cites the need, among other things, to address the lack of an implementation strategy, to engage cross-sectorally and to "mainstream" forest sector development activities into overarching socio-economic objectives such as poverty alleviation, sustainable development and maintenance of 
"global commons" resources. Douglas recommends more reliance on partnerships, deeper sector analysis for better understanding of borrower countries, stronger co-ordination among donors; guarantees for risk mitigation (through the World Bank's Multilateral Investment Guarantee Agency) and making forests a focus of issues-based lending (through targeted allocations).

\section{Kari Keipi. 2000. Forest Financing in Latin America and the Caribbean: A View from the Inter-American Development Bank. IDB, Washington, D.C., U.S.A.}

In a paper that emphasises the need to create an enabling environment for SFM, Keipi begins by identifying factors that affect forestry financing possibilities in Latin America and the Caribbean. He then explores financial instruments for forest conservation, describes rural credit as a tool with unrealised promise for forest financing and outlines the role of the Inter-American Development Bank group in forestry.

Political and macroeconomic stability, access to land and property rights are among the key factors influencing forest financing possibilities in Latin America and the Caribbean; also important are an effective and appropriate regulatory framework, clear forest policies and participatory decision making in implementing policies. The world-wide trend of declining official development aid is occurring in Latin America and the Caribbean, while the role of the private sector is increasing. Keipi believes a major role of external public-sector funding is to foster private-sector financing in the region - not through subsidies, but by contributing to governments' efforts to create a more conducive environment for investment. In the future, Keipi says, private investment should be encouraged not only for SFM in production forests, but also for protected areas, ecotourism development and conservation set-asides.

Keipi notes that creating an enabling environment for investment in developing countries and countries in transition often involves more general challenges of state modernisation, such as decentralising forest institutions, designing and implementing forest policies, and fostering ethics and transparency in governance and business. Improving competitiveness requires a strengthening of infrastructure, financial services and other aspects of the business of forest business development (Keipi sees a role here for investment promotion measures). More directly, Keipi believes that the potentially most powerful source of financial resources for productive forestry is rural credit, and he calls for strengthening its capacity.

Despite the current climate of limited official demand for lending for forestry development, Keipi sees many opportunities for future investment. He asserts that the low demand is in large part the result of a lack of knowledge about available financing opportunities 
among ministries of finance and national planning agencies, and calls for promoting greater awareness among these audiences. Another group to target if investments are to increase is commercial banks and rural credit institutions, which need to better understand potential profitability and risks of forestry investment and its competitiveness in relation to other sectors. Keipi believes that in promoting greater investment in forestry to these and other groups, increased attention should be given to the possibility of creating markets not only for traditional timber products but also for non-wood products and environmental products and services.

\section{Kanta Kumari. 2000. The Global Environment Facility: Experiences and Trends - Lessons for Sustainable Forest Management. Global Environment Facility, Washington, D.C., U.S.A.}

Kumari describes the relevance and lessons of the Global Environment Facility's biodiversity programme and other programmes in relation to SFM. The GEF, which is the funding mechanism of the U.N. Convention on Biological Diversity, was created to provide financing for environmental activities that support the adoption of sustainable development in developing countries and countries with economies in transition. Areas of focus include biological diversity, climate change, international waters, ozone layer depletion, desertification and deforestation.

From 1992 to 2000 , the GEF provided mote than $\$ 1.18$ billion to cover the incremental costs of biodiversity conservation in 123 countries and mobilised an additional $\$ 2.01$ billion in national and international co-financing. Of this, the forests programme is the largest, with a GEF allocation of $\$ 505.92$ million and co-financing of more than $\$ 1.03$ billion. The portfolio mainly addresses tropical humid forests. More than 70 percent of GEF projects in the current biodiversity portfolio, and the forest programme as well, have focussed largely on protected areas; however, the number of proposals and projects that seek to address sustainable use and conservation in the larger landscape is growing.

Recently, there have been calls for the GEF to address sustainable use and conservation through more integrated approaches, and to work across sectors. Policy reforms and supporting legislation are seen as the areas most likely to achieve significant global impacts, especially given the limited availability of funds. The GEF has expanded its approach to biodiversity conservation in a couple of ways. First, it has shifted from a focus primarily on protected area focus to one that encompasses the overall landscape. In addition, it has moved from an emphasis on project-based activities to more strategic interventions. Thus, GEF interventions are possible at three complementary levels: project or site based, contributing to a more enabling environment and programme-plus-sector based. 
Regarding GEF's role and scope with regard to SFM, Kumari sees a greater potential contribution because of the programme's expanded scope. He says: "Expansion from a largely protected area focus to effectively secure biodiversity within the overall landscape, is very consistent with the need to move from islands to networks through a mosaic of land uses, including protection and production forests." Empowering and strengthening communities as part of countries' efforts to create conditions conducive to biodiversity conservation would improve the effectiveness of the GEF as an instrument for the biodiversity convention, Kumari argues. Not to be overlooked, she notes, are SFM activities related to biodiversity conservation in ecosystems of arid/semi-arid zones and mountain ecosystems.

Per Ryden and Simon Quatrini. 2000. Experiences of and Lessons in Sustainable Forest Management Financing. Global Mechanism/U.N. Convention to Combat Desertification, Rome, Italy

Ryden and Quatrini describe the Global Mechanism of the U.N. Convention to Combat Desertification with regard to SFM and its relation to other mechanisms. Hosted by (but not part of) the International Fund for Agricultural Development, the Global Mechanism is not a "fund' but a catalyst for mobilising resources. Under the convention on desertification, the Global Mechanism's mandate is "to promote actions leading to the mobilisation of substantial financial resources, including for the transfer of technology, on a grant basis, and/or on concessional or other terms to affected developing country parties." It mobilises resources from multi-channel financing sources and also acts as a honest broker seeking to match demand and supply.

Its operational strategy is based on three basic concepts: mainstreaming, partnership building and achieving a multiplier effect. The authors suggest that the U.N. Forum on Forests could forge appropriate strategic partnerships between the Global Mechanism and the main actors involved in promoting SFM at national, regional or international levels, in the context of joint efforts to combat land degradation.

\section{National Funding Mechanisms}

Kenneth L. Rosenbaum and Jonathan M. Lindsay. 2000. An Overview of National Forest Funds: Current Approaches and Future Opportunities. FAO, Rome, Italy

Rosenbaum and Lindsay have compiled what is probably the most comprehensive and up-to-date review of national forest funds available, covering 41 countries and more than 50 funds in both developing and developed countries. Presenting the information 
systematically, they begin by describing national forest funds and move on to discuss their strengths and weaknesses and possible future roles they might play.

Such funds have been created for purposes ranging from support for government forestry activities to functions that have more general benefit for the forest sector, such as market promotion, research, public education, insect and disease control, and fire fighting. Funds can also directly support private and community forestry, whether in terms of resource management, value-adding activities, economic development or promoting noncommodity uses of forests, such as production of environmental services. Among their advantages, national forest funds help meet the need for long-term investment, shield the forest sector against the fluctuations and unpredictability of national budgets, help stimulate more effective forest management by government agencies and enable greater oversight of forest spending. But they also have possible disadvantages that may include trapping capital in the forest sector, preventing ideal allocation of government budgets, conveying misleading economic signals to bureaucrats and facilitating corruption.

Looking ahead, the authors identify a number of potential constructive uses of national forest funds, such as using them as tools for decentralisation and devolution of forest management, to encourage private-sector initiatives, to increase accountability and transparency, and to promote the production of environmental goods and services.

\section{Indonesia}

Herman Haeruman Js. 2000. Financing Integrated Sustainable Forest and Protected Areas Management in Indonesia: Alternative Mechanisms to Finance Participatory Forest and Protected Areas Management. Indonesia

In discussing forest sector financing conditions in Indonesia, Haeruman looks at funding for a particular subset of sustainable forest management: protected areas. After explaining the country's system of protected areas, he describes the new paradigm for national park financing that is now emerging and its implications.

Given the considerable (potentially re-investable) economic and financial benefits that may be derived from sustainable use of timber and non-timber products from natural forests, Haeruman believes the greatest area of need in financing of sustainable forest management in Indonesia is for management of protected areas. The present economic, political and legal uncertainties in the country, he suggests, offer excellent opportunities to rethink past ways of doing things. The passage of legislation mandating more democratic control of financial and natural resources through decentralisation and local fiscal autonomy, for example, has potentially important ramifications for national parks. 
Questioning current methods of allocating funds for parks, Haeruman contends that financing mechanisms should assign costs to those who capture the benefits, should support the conservation goals of individual parks and should consider the overall objectives of the park system. The tendency should not be to look at what parks cost and the inputs they need, he says, but whether these costs and objectives are justified.

The new paradigm is based on the principle that "the beneficiary pays." Under this approach, Haeruman says, the government can consider at least seven ways to generate new finances for its 39 parks; there would no longer be a single "right" financing approach for all the parks, or even a single approach for any one park. The various financing strategies he cites are: a) more efficient and cost-effective use of existing resources, with resources allocated to match particular needs; b) self-financing through non-tax revenues (especially applicable to parks with high-level use); c) partnerships between the private sector and local communities to manage resources; d) debt-for-nature swaps, especially in cases where there are major conservation objectives or important species to protect, such as orang-utans; e) carbon offsets (applicable to parks with large forests or bordering large forest operations); f) concessions for park management or quasi-privatisation; and g) conservation trust funds. Such approaches could be applied to protection forests and other nature reserves in Indonesia, which together encompass more than 48 million hectares.

\section{Norway}

\section{Knut Clstad. 2000. Financing Sustainable Forest Management in Norway. Ministry of Agriculture, Oslo, Norway}

istad begins by placing forest sector funding in Norway in the context of overall characteristics of the country's forest sector and funding for it, and concludes by describing recent developments and future directions. Norwegian forestry funding is based on publicprivate partnership, and the rate of investment in the forest sector averages 17 percent measured as a share of the gross value of the output. A basic operating principle is that forestry is an economic activity that should be able to generate competitive income relative to other land uses. Effectiveness of investment arrangements depends on a clear regulatory framework, good organisation of the many small forest owners, support and guidance from local government, strong extension and technical support services.

An important attribute of forestry that affects the public role in funding is the ownership pattern: the vast majority (87 percent) of Norway's forest land is privately owned (76 percent by individuals); overall there are about 125,000 forest properties in the country. 
Under this ownership structure, Norwegian forest authorities must deal with approximately 125,000 decision-makers, who may have many different objectives for management of their forest resources and investment preferences. The State has the role of ensuring long-term investment, which it does through several main financial instruments: the Forest Trust Fund, tax incentives and cost-share programs and grants financed by the state budget.

The Forest Trust Fund together with direct private resources is the main source of investment in forest resources, making up 60 percent to 70 percent of the total. Revenue for the trust fund comes from legal requirements that all private and public forest landowners pay into the fund 8 to 25 percent of the gross value of timber sold. Deposits into the trust fund remain with the forest holding; this means the fund cannot be separated from the property, whether by sale, transfer or mortgaging.

Land owners can deduct the amount of their deposit into the trust fund from their federal income taxes. When the funds are withdrawn and used for forestry practices, a proportion of such investments (usually 35 percent) can also be deducted from annual income taxes. Cost-share programmes and public grants meet 30 percent to 40 percent of the total long-term investment in the forest sector that does not come from trust fund and private investment. This public support through grants or cost-share programs focuses on the long-term management of forest resources.

Regarding the future, Norway's Parliament has accepted a proposal to widen the purpose of the trust fund to include investment for environmental purposes and to collect money from the private sector in support of forest research and development. The declining level of investment and other developments pose challenges that may require refinement of existing incentives in forest policy.

\section{Russia}

Anatoly Petrov. 2000. Financing Sustainable Forest Management in Russia and the Commonwealth of Independent State Countries: Alternative Mechanisms to Finance Participatory Forest and Protected Areas Management. Russian Institute of Continuous Education in Forestry, Russia

Petrov looks at the discouraging state of the forest sector after the post-Soviet Union dislocation of institutions and economies in the region. He describes the weaknesses of present sector financing arrangements and suggests improvements. A key message is that administrative setting of prices for forest resources and their transport has major effects on profitability and consequently on the generation of investable surpluses. Set 
by decree rather than by the market, stumpage fees in Russia in 1999 averaged US\$ 0.6 per cubic meter, which was considerably lower than in all economically developed European countries. For roundwood exported from Russia, stumpage charges were so low the forest owner's economic interests are not covered.

Under central planning, the State assumed the main share of the costs of transporting timber over long distances, but under the new market-oriented economy, Siberian forest resources have become economically inaccessible for the market in European Russia, where 80 percent of the country's population lives. Petrov advocates replacing the present system with a combination of rental charges based on proper economic calculations and negotiation, minimum stumpage rates dependent on norm-based costs of forest management and financial flows that safeguard the interests of all stakeholders. If such changes were introduced, he predicts, there would be increased capacity and interest in investing in forest sector development in the regions because of the possibility of higher returns.

\section{Vietnam}

Nguyen Xuan Nguyen. 2000. Experiences and Future Directions of Forestry Funding in Vietnam. Ministry of Agriculture, Vietnam

Nguyen describes Vietnam's reforestation efforts and their financing. The country is now in its second Forestry Development Program, which involves reforestation of 5 million hectares and initiatives to promote investment in the forest sector. For forest programme financing, Vietnam relies on a combination of State budget investment (focused mainly on protected areas and watershed forestry), provision of credit for production forest plantations and promotion of investment by forest-affected industries.

According to Nguyen, notable successes of the country's first forestry development programme (1992-98) included progress in improving protected and managed areas and in employment and rural infrastructure development. Among the important lessons learned is that plantations must better consider economic viability and the need to meet various interests of the State and local communities. Problems in current funding for forests include inadequate state budget allocations, bureaucratic delays, poor monitoring, poor information on profitability and low private-sector participation. The credit component of funding involves banks, foreign companies in joint ventures and private capital. Among the constraints, banks are reluctant to lend for the long term to farmers and to companies with limited collateral, farmers are more inclined to borrow for quicker return options than forestry and the cost of loans (in farmers' perception, at least) is high. 
An innovative approach being considered is based on the fact that industries such as inland river navigation, hydroelectricity generating stations, agricultural cropping and acquaculture development all benefit from the role of forests. Thus, the government plans to encourage them to contribute to reforestation by offering incentives, if they participate in afforestation; these include reduced taxes on profits, tax exemptions and allocation of forest land. This proposed approach has not yet been approved by government. For its part, faced with budget deficits, the Vietnamese government has sought to mobilise "social investment," including funding from domestic sources (such as farm households and private companies). In addition, it is seeking foreign (private) direct investment and official development assistance - efforts that all suffer at present from a lack of appropriate policies.

\section{Endnotes}

${ }^{22}$ Lai Har Chan's paper was not prepared for the workshop but was submitted to record her presentation at the workshop.

${ }^{23}$ Raga claims that this discourages investment in SFM because the targets seem unreachable, troublesome, expensive and even doubtful in some cases.

${ }^{24}$ For example, the costs for conservation of non-endangered species or of strict regulations aimed at preserving biodiversity and the landscape in non-scarce forests, whose main purpose is timber production, a function benefiting society.

${ }^{25}$ A vast number of poor farmers with low levels of education, information access and ownership perform collect fuelwood on timber lands belonging to the State or outside investors. Many of them operate outside the formal economy; others operate without any management plan.

${ }^{26}$ Current annual forestry official development assistance to developing countries averages about a tenth of this.

${ }^{27}$ Productive, protective, social functions of forests. 
Part III:

Annexes

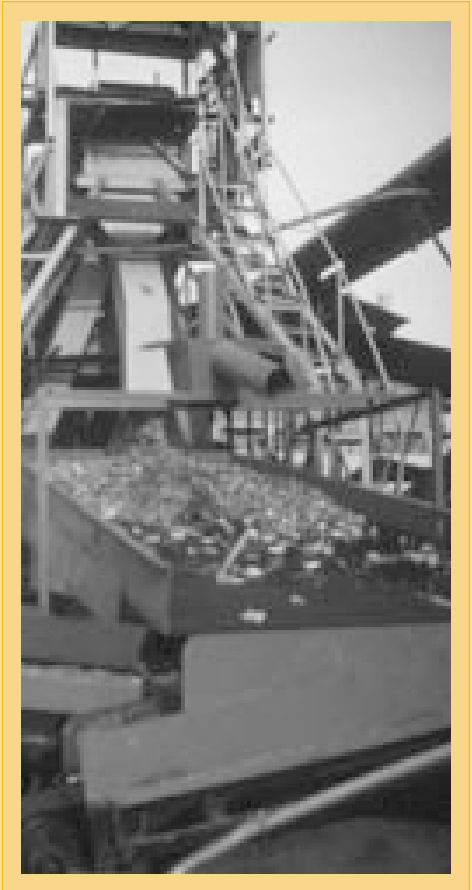




\title{
Annex 1: \\ Statements at Ceremonial Events
}

\author{
OPENING SESSION OF THE WORKSHOP
}

(22 January 2001)

\section{Welcome Address by Bjarne Håkon Hanssen}

\section{Minister of Agriculture \\ Norway}

\begin{abstract}
Your Excellencies,
Ladies and Gentlemen,

Colleagues and friends,
\end{abstract}

On behalf of the Norwegian Ministry of Agriculture and the Ministry of Foreign Affairs, I would like to welcome you all to Norway and to Holmenkollen Park Hotel. I think this is a unique opportunity to discuss the important issue of financing sustainable forest management more in detail. The fact that you have chosen to visit Norway in the darkest and coldest time of the year should ensure that you stay inside and thus contribute to a productive workshop.

Forest resources have played a significant role in the development of the Norwegian society and culture. During the last half of the last century, new dimensions were added to the importance of the forest resources in our country. Parallel with the commercial utilisation of the forest resources, emphasis has been put on the environmental and social aspects of forests and forest land. This is duly reflected in the development of our national forest policy.

Our national forest policy aims to enhance the contribution of the forest sector to the welfare of the people, contribute to more sustainable consumption and production patterns, and contribute to viable rural communities. To fulfil this objective it is necessary to encourage economic development from forest-based activities and to ensure sustainable management practises. 
My government entered office last March, and from that time on I have had an opportunity to follow more closely the national forest issues as well as forest issues on the international agenda. From my previous position as a member of the Norwegian Parliament, I also had responsibilities within the Labour party that entailed keeping an eye on international forest policy issues. However, it was actually during a meeting in the Nordic Council of Ministers at Svalbard (Spitsbergen) last summer that I got a more comprehensive introduction to the international forest policy dialogue by Dr. Jag Maini, for which I am very grateful.

Along with our national efforts in the development of our own forest policy, my government sees sustainable forest management also as a responsibility in our activities abroad.

In our forest policies, adopted by Parliament, we emphasise that management of natural and environmental resources is to be given high priority in Norway's bilateral and multilateral development co-operation, and forestry measures will be given a central role. The measures will vary in geographical areas and will be based on the recipient countries' level of development and the nature of the environmental problems. An important principle will be to contribute to enabling the recipient countries themselves to identify and implement the measures that are necessary to create sustainable forest management.

Thus, the discussion you will have during these days in Oslo is connected to both our national forest policies and the priorities of our development co-operation policies. I am fully aware of the complexity, and, indeed, some of the controversies of the topic. I wish you a fruitful and productive workshop, and I am convinced that the outcome will contribute meaningfully to the future work of the United Nations Forum on Forests.

Thank you for your attention. 


\title{
OPENING SESSION OF THE WORKSHOP
}

\author{
(22 January 2001)
}

\author{
Opening Statement of Mafa E. Chipeta \\ Chairman, Oslo Workshop Steering Committee \\ and \\ Deputy Director General, CIFOR
}

Mr. Oluf Aalde, Director General of Forestry, Norway and Chairman of the Workshop Hon. Bjarne-Hakon Hanssen, Minister of Agriculture, Norway

Mr. Erik Bjornebye, Ministry of Foreign Affairs, Norway

Mr. Richard Dewdney and Ms. Penny Davies, representing the U.K. Department for International Development (DfID)

Mr. Orlando Rebagliatti, Ambassador of Argentina to Norway

Members of the Workshop Steering Committee

Dr. Jag Maini, Co-ordinator and Head, UNFF Secretariat

All participants and colleagues from partner organisations and countries

As the first speaker this morning, I will set an example for brevity. I speak in my status of Chairman of the Steering Committee for this workshop, the members of which represented the six co-sponsoring governments: Brazil, Denmark, Malaysia, Norway, South Africa, and the United Kingdom. I also speak on behalf of CIFOR, the institution responsible for organising this meeting, in my capacity there as Deputy Director-General. Prof. Jeffrey Sayer, Director-General of CIFOR, has asked me to convey his regrets at not being able to come; he sends his best wishes for a successful meeting.

Mr. Chairman, I have sought this early opportunity to, on behalf of the Steering Committee, thank all that have contributed and are contributing to the success of this event. I cannot be exhaustive; I therefore thank all, but mention in particular:

Honourable Minister Hanssen, for sparing time to join us and to open this workshop

The Government of Norway, for kindly hosting the meeting and the excellent arrangements made for it

The co-sponsoring countries: Brazil, Denmark, Malaysia, Norway, South Africa, and the United Kingdom, and the Steering Committee members they designated to guide the workshop 
The co-funding countries: Norway and the United Kingdom

The Norwegian Forestry Society, for outstanding co-operation and dedication during preparations, and in particular Mr. Tore Molterberg, whom the Society has delegated to take direct responsibility for this meeting

Partner agencies backstopping the process, in particular FAO, UNDP, the World Bank, and the UNFF Secretariat; they have invested much time and some also resources to contribute papers, review material, and to attend

All contributors of papers and ideas, whether institutions or individual authors

Resource persons and the facilitator who will lead us through this week CIFOR colleagues in both technical and logistical roles

All others who have contributed to the workshop in various ways or continue to do so.

As an organisation, CIFOR feels honoured for being entrusted with responsibility for convening this meeting and providing the professional and logistical support for it. As a member organisation of the Inter-Agency Task Force on Forests (ITFF), CIFOR has willingly taken on the task as a contribution, among other roles, in support of the international community's policy dialogue on forests. Partner members of the ITFF have shown abundant willingness to co-operate with CIFOR in this endeavour. It is thus a pleasure to see among participants at this meeting colleagues from FAO, UNDP, and the World Bank with whom we have co-operated closely in the lead-up to Oslo.

Mr. Chairman, I would like at this stage to introduce the members of the Steering Committee who have done much to guide us at CIFOR and the IFF Secretariat as we prepared for this meeting: Mr. Everton Vargas (Brazil), Mr. Thure Christiansen (Denmark), Ms. Lai Har Chan (Malaysia), Mr. Knut istad (Norway), Ms. Lael Bethlehem (South Africa), and Mr. Richard Dewdney (United Kingdom). I take the opportunity to thank them most sincerely for their support and inputs.

I have four main messages to communicate:

the first is that active participation by all is the only way to get the most out of this workshop

the second is that, in view of efforts to seek balance in participation between the public and private sectors and among geographical regions, we hope this will be reflected in the level of inputs to the dialogue; international dialogue needs to accommodate the diversity of views everyone's presence here makes possible 
the third is that this is an expert meeting, not a negotiation forum; all of you are therefore invited to speak freely and to give professional rather than official views

the last is to give assurance to authors of the excellent papers before us: although they cannot introduce their papers in detail, the value of their ideas has many other important dissemination avenues and will influence thinking and perceptions (channels included are the Internet, workshop reports, and presentation of Oslo outcomes in other fora).

Mr. Chairman, in the country where I live, Indonesia, there is a tradition which has much merit. I adopt it now and seek forgiveness for any oversights, weaknesses, or deficiencies that may come to light regarding the organisation of this meeting. I accept responsibility for these and pledge to do better next time.

Mr. Chairman, I now take pleasure in handing the meeting over to you, with my thanks and best wishes. 


\title{
RECEPTION FOR PARTICIPANTS
}

\author{
(24 January 2001)
}

\section{Welcome Address by Anne Kristin Sydnes}

\section{Minister of International Development \\ Norway}

Your Excellencies,

Ladies and Gentlemen,

Colleagues and friends,

It gives me great pleasure to welcome you to this reception, and to Oslo; a city blessed with an abundance of surrounding forests. We, the almost half a million people living in this city, take pride in this nature reserve and source of recreation, only minutes away. And we make sure to take very well care of it.

I know that you have had long days of hard work here in Oslo, discussing issues of paramount importance to us all. We will continue the discussions tonight, but I also hope we will have some time to get to know each other better, to nurture friendship.

Deforestation is a major environmental, social, and economic problem. Developing countries are hit the hardest. The signs of the times are worrying.

Here in Oslo you have addressed the issue of financing sustainable forest management, building on the results of IFF4 (Intergovernmental Forum on Forests). This is a complex issue, and a controversial one. I understand that you nevertheless have covered a lot of ground. I am sure that your work will provide valuable inputs to the efforts of the United Nations Forum on Forests.

Financing is important. However, without a sound national policy framework, finance will change very little. We must therefore constantly review our own efforts in this field, and become more effective. 
On Monday, my colleague, the Minister of Agriculture and Forestry, presented aspects of our national forest policy to you all. I would like to take the opportunity to say a few words on how Norway addresses the various aspects of sustainable forest management in our development co-operation:

First and foremost, the main goal of Norway's development co-operation is the alleviation of poverty, through economic growth and social development, without depleting the natural resource base.

Second, the main precondition for all Norwegian forestry assistance is the expressed political will in our partner countries to improve the management of forest areas, and to involve local people in this endeavour. Third, Norwegian efforts in this area are guided by international conventions and agreements. We support efforts to strengthen partner countries' ability to comply with international agreements in the areas of forestry, biodiversity, global warming, and desertification.

Our primary partners in bilateral co-operation are the governments of our partner countries. In the future, however, I do believe that we all must co-operate more extensively with the private sector. Indeed, I see that the role of private-sector finance figures prominently on your agenda.

The role played by civil society is also becoming increasingly important. NGOs, universities, and other institutions are important stakeholders, and we need their active participation.

Norway supports forestry programs in many countries, including in Tanzania, Malawi, and most notably, Uganda. Our extensive and very close forestry co-operation with Uganda was reinvigorated in the late1980s, but dates back all the way to the 1960s. The cooperation focuses on capacity building through partnership and, notably, two-way learning - added value both ways. Among its most important results is a mapping of the biomass and vegetation in all of Uganda, a key component in sustainable forest management. The state-of-the-art vegetation maps have won international acclaim.

The notion of partnership is equally important in multilateral co-operation. In this regard, I particularly want to mention the World Bank/World Wildlife Fund Alliance for Forest Conservation and Sustainable Use. This is a new form of strategic partnership in which different actors pool their resources to reach common goals.

In my opinion, alliances such as this one hold much promise. To promote more sustainable forest management worldwide, we need to explore new ways and means of co-operation. 
Norway will continue to be active in this field. I, and the Minister of Agriculture and Forestry, look forward to working with you all.

A Norwegian writer, Nils Kjær, once wrote: "A people which does not preserve the forests live from hand to mouth, like barbarians, each generation single-handedly and single-mindedly chasing modernity."

This writer died in 1924. He was ahead of his time, then. Perhaps he still is.

But we're gaining in on him, and we have to.

Thank you, and enjoy. 


\section{Annex 2: \\ Workshop Agenda}

\section{Agenda item I: Preliminaries}

Registration

Preliminary remarks

Mr. Mafa Chipeta, Chair, Workshop Steering Committee

Mr. Oluf Aalde, Director General of Forestry, Norwegian Ministry of Agriculture

Welcome address (Mr. Bjarne Hakon Hanssen, Norwegian Minister of Agriculture

Setting the stage: where are we on finance dialogue (from UNCED to UNFF and the future)?

Mr. Jag Maini, Coordinator, IFF Secretariat

Mr. Ralph Schmidt

\section{Agenda item II: Private Sector Financing}

Private sector financing - trends, opportunities and constraints

Regional and corporate perspectives on private sector financing of SFM

\section{Agenda item III: Investment Promotion Entity (IPE)}

Investment Promotion Entity (IPE) - feasibility and operationalisation

\section{Agenda item IV: The Global Forest Fund and other means of increasing financial resources from all sources}

The Global Forest Fund - from Rio to IFF4

Getting the best out of existing financial sources and mechanisms.

Selected approaches towards new funding mechanisms: consortium approach to international funding. 


\section{Agenda item V: Highlights and the way forward}

Highlights from the workshop and matters to draw to the attention of the UNFF.

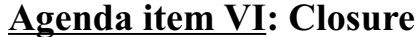

Closing session. 


\section{Annex 3: \\ List of Documents}

\section{An Enabling environment for investment in SFM}

Ljungman, Lennart and C.T.S. Nair: Changing perceptions on technical assistance in support of sustainable forest management.

Chan, Lai Har: Towards an international enabling environment for investment in sustainable forest management.

\section{Private sector financing of sustainable forest management}

Gregersen, Hans and Arnoldo Contreras-Hermosilla: Investing in the future: the private sector and sustainable forest management. [Lead paper]

Landrot, Jean Jacques and Steven Speed: Private Sector Investment in Sustainable Forest Management in Humid Tropical Africa. Interafrican Forest Industries Association / Association interafricaine des industries forestières. Abidjan / Paris.

Chan, Barney S.T.: The Private Sector and Sustainable Forest Management Southeast Asian perspective. Sarawak Timber Association, Malaysia

Tomaselli, Ivan: The Private Sector and Sustainable Forest Management-South America Perspective. STCP, Brazil

Raga Castellanos, Fernando: The Private Sector and Sustainable Forest Management - A Private Perspective from South America's Southern Cone. Santiago, Chile.

Mertz, Peter: Investing in sustainable forestry. UBS Timber Investors (USA)

Brand, David: Mechanisms to Encourage Private Capital Investment in the Environmental Services of Forests. Hancock Natural Resources Group - Australia Muthoo, M. K.: Certification and Sustainable Forest Management. Forest Stewardship Council, Mexico 
Goldbatt, Mike: The Private Sector and Sustainable Forest Management Perspective from Southern Africa. Natural Capital, South Africa

\section{Investment Promotion Entity (IPE) as a potential means for financing SFM}

Chipeta, Mafa E. and Mahendra Joshi: Feasibility and Operationalisation of an Investment Promotion Entity (IPE) for Sustainable Forest Management Highlights from the Main Papers. CIFOR, Bogor, Indonesia and UNFF Secretariat, New York, USA

Moura-Costa, Pedro, Lionel Fretz, \& Gerald Kohn: Assessing the Feasibility and Operationalisation of an Investment Promotion Entity (IPE) for Sustainable Forest Management. Ecosecurities, UK [Lead paper]

Salmi, Jyrki, Tapani Oksanen, Markku Simula: Assessing the Feasibility and Operationalisation of an Investment Promotion Entity (IPE) for Sustainable Forest Management:Demand and Supply Aspects. Indufor Oy, Finland

Other means of increasing financial resources from all sources, including the Global Forest Fund

$\underline{\text { Global Forest Fund and related mechanisms }}$

Joshi, Mahendra and Mafa Chipeta: The Global Forest Fund-from Rio to IFF4: What Issues Remain? CIFOR, Bogor (Indonesia) and UNFF Secretariat, New York, USA

[Sole paper]

Ganguli, Barin: Global Forest Funding - Exploring Consortium Financing of Sustainable Forest Management. New Delhi, India [Lead paper]

Kufakwandi, Frank S.: Consortium Funding for Sustainable Forest Management: African Perspectives and Priorities. African Development Bank, Abidjan, Ivory Coast 
Other means of increasing financial resources from all sources

International

Douglas, Jim: Financing Sustainable Forest Management: Doing more with (probably) less. World Bank, Washington DC, USA [Lead paper]

Kumari, Kanta: The Global Environment Facility: Experiences and Trends Lessons for Sustainable Forest Management. Global Environment Facility (GEF), Washington DC, USA)

Ryden, Per and Simon Quatrini (2000): Experiences of and Lessons in Sustainable Forest Management Financing. Global Mechanism/UN Convention to Combat Desertification, Rome, Italy

Keipi, Kari: Forest Financing in Latin America and the Caribbean: a view from the Inter-American Development Bank. IADB, USA

National

Rosenbaum, Kenneth L. and Jonathan M. Lindsay: An Overview of National Forest Funds: Current Approaches and Future Opportunities. FAO, Rome, Italy [Lead paper]

Haeruman Js., Herman: Financing Integrated Sustainable Forest and Protected Areas Management in Indonesia: Alternative Mechanisms to Finance Participatory Forest and Protected Areas Management . Bogor Agricultural University (IPB), Bogor, Indonesia

istad, Knut (2000): Financing Sustainable Forest Management in Norway. Ministry of Agriculture, Oslo, Norway

Petrov, Anatoly Prof. (2000): Financing Sustainable Forest Management in Russia and the Commonwealth of Independent State Countries: Alternative Mechanisms to Finance Participatory Forest and Protected Areas Management. Russian Institute of Continuous Education in Forestry, Russia

Nguyen Xuan Nguyen: Experiences and Future Directions of Forestry Funding in Vietnam. Ministry of Agriculture, Vietnam 


\section{Annex 4: \\ List of Participants}

\section{Developing Countries}

\section{Africa}

\begin{tabular}{|c|c|c|c|}
\hline No. & Name & Address & E-mail/Tel/Fax \\
\hline 1. & Bethlehem, Lael & $\begin{array}{l}\text { Chief Director: Forestry } \\
\text { Department of Water Affairs } \\
\text { \& Forestry } \\
\text { Private Bag X313 } \\
\text { Pretoria } 001 \text {, } \\
\text { REPUBLIC SOUTH AFRICA }\end{array}$ & $\begin{array}{l}\text { Lael@dwaf.pwv.gov.za } \\
\text { Tel: (27) } 123368753 \\
\text { Fax: (27) } 123368942\end{array}$ \\
\hline 2. & Kojwang, Harrison O. & $\begin{array}{l}\text { Director of Forestry } \\
\text { Ministry of Environment and Tourism } \\
\text { Directorate of Forestry } \\
\text { Private Bag 13346, Windhoek, } \\
\text { NAMIBIA }\end{array}$ & $\begin{array}{l}\text { Kojwang@forestry.met.gov.na } \\
\text { Tel: (264) } 61221478,248214 \\
\text { Fax: (264) } 61222830\end{array}$ \\
\hline 3. & Lokwiya, Justin & $\begin{array}{l}\text { Head, Uganda Forest Sector Co- } \\
\text { ordination Secretariat } \\
\text { Ministry of Water, Land and } \\
\text { Environment } \\
\text { Forest Sector Co-ordination } \\
\text { Secretariat } \\
\text { Baumann House, Parliament Avenue, } \\
\text { P.O.Box } 27314, \text { Kampala, UGANDA }\end{array}$ & $\begin{array}{l}\text { JustinL@ugandaforests.org } \\
\begin{aligned} & \text { Tel: }(256) 41340684 \\
&(256) 77440148 \\
& \text { Fax: (256) } 41340683\end{aligned}\end{array}$ \\
\hline 4. & $\begin{array}{l}\text { Nkosi, Dickson } \\
\text { Mtsamayi }\end{array}$ & $\begin{array}{l}\text { Deputy Director, Stakeholder liaison } \\
\text { Department of Water Affairs and } \\
\text { Forestry } \\
157 \text { Schoeman Street, Pretoria } 0001 \\
\text { REPUBLIC OF SOUTH AFRICA }\end{array}$ & $\begin{array}{l}\text { Law@dwaf.pwv.gov.za } \\
\text { Tel: (27) } 123367433 \\
\text { Fax: (27) } 123237054\end{array}$ \\
\hline 5. & Nyasulu, Kenneth & $\begin{array}{l}\text { Director of Forestry } \\
\text { Department of Forestry } \\
\text { P.O. Box 30048, Lilongwe 3, } \\
\text { MALAWI }\end{array}$ & $\begin{array}{l}\text { Dirfor@sdnp.org.mw } \\
\text { Tel: (265) 771000/773462 } \\
\text { Fax: (265) } 784268\end{array}$ \\
\hline 6. & Tabi, Agyarko & $\begin{array}{l}\text { Planning Officer } \\
\text { The Policy Planning Monitoring and } \\
\text { Evaluation Division (PPMED) } \\
\text { Ministry of Lands and Forestry } \\
\text { P.O. Box M. 212, Accra, GHANA }\end{array}$ & 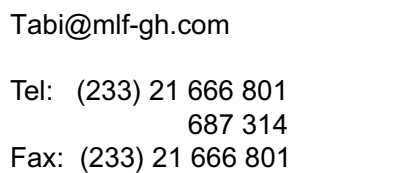 \\
\hline
\end{tabular}




\section{Asia-Pacific}

\begin{tabular}{|c|c|c|c|}
\hline No. & Name & Address & E-mail/Tel/Fax \\
\hline 7. & Biglarbeigi, Bizhan & $\begin{array}{l}\text { Member of High council forest range and soil } \\
\text { Forest \& Range Organization } \\
\text { Ekbatan B4 No. 305, Tehran } \\
\text { IRAN }\end{array}$ & $\begin{array}{l}\text { Faro_high_concil@mavara.com } \\
\text { Tel: (98)212446505/ } 2446547 \\
\text { Fax: (98) } 212446547 / 2446551\end{array}$ \\
\hline 8. & Chan, Lai Har & $\begin{array}{l}\text { Undersecretary of the Forest Division } \\
\text { Ministry of Primary Industries } \\
8^{\text {th }} \text { Floor, Menera Dayabumi } \\
\text { Jalan Sultan Hishamuddin } \\
50654 \text { Kuala Lumpur, MALAYSIA }\end{array}$ & $\begin{array}{l}\text { Chanlh@kpu.gov.my } \\
\text { Tel: (60) } 322756150 \\
\text { Fax: (60) } 322745649\end{array}$ \\
\hline 9. & Golman, Martin & $\begin{array}{l}\text { Divisional Manager - Forest Planning } \\
\text { PNG Forest Authority (Frangipani Street, } \\
\text { Hohola) } \\
\text { National Forest Service } \\
\text { P.O. Box 5055, Boroko, National Capital } \\
\text { District } \\
\text { PAPUA NEW GUINEA }\end{array}$ & $\begin{array}{l}\text { Mgolman@datec.com.pg } \\
\text { Tel: (675) } 3277874 \\
\text { Fax: (675) } 3254433\end{array}$ \\
\hline
\end{tabular}

10. Haeruman, Herman Deputy Chair for Regional Development \&

D5herman@rad.net.id

Natural Resources

National Development Planning Agency, $\quad$ Tel: (62) 21334187 BAPPENAS

Jl. Taman Suropati No. 2, $5^{\text {th }}$ Floor, Jakarta

Fax: (62) 213144131 INDONESIA

11. Kim, Joong Myung Research Scientist Korea Forest Research Institute 207 Chungyangri-dong

Dongdaemun-ku, Seoul REPUBLIC OF SOUTH KOREA
Jmkim99@foa.go.kr

Tel: (82) 29612533

Fax: (82) 29612530

Nur@dephut.cbn.net.id Nurma@cbn.net.id

Tel: (62) 215730479

Fax: (62) 215720216 Jl. Jend. Gatot Subroto Jakarta, INDONESIA

13. Nguyen, Xuan
Nguyen

Deputy Director/Economist Economic Secretariat 1 A Hung Vuong Street Hanoi, VIETNAM
Nguyentm@hn.vnn.vn

Tel: (84)4 8045296/822 5397

Fax: (84) 48239042

14. Yuanhui, $\mathrm{Hu}$

Deputy Director of the Division of Multilateral Co-operation International Forestry Co-operation Center State Forestry Administration 18 Hepingli Dongjie Beijing 100714, P.R. CHINA
Ifcc@cj.net.cn

Tel: (86) $1084238941-45$

Fax: (86) 1084238950 


\section{Latin America}

\begin{tabular}{|c|c|c|c|}
\hline No. & Name & Address & E-mail/Tel/Fax \\
\hline 15. & $\begin{array}{l}\text { Diaz-Silveira, Modesto } \\
\text { Fernandez }\end{array}$ & $\begin{array}{l}\text { Environmental Policy } \\
\text { Directorate } \\
\text { Ministry of Science, } \\
\text { Technology \& Environment, } \\
\text { Prado y San Jose } \\
\text { Ciudad de la Habana } \\
\text { CUBA }\end{array}$ & $\begin{array}{l}\text { Mffds@hotmail.com } \\
\text { Mffds@yahoo.com } \\
\text { Tel: (537) } 670598 \\
\text { Fax: (537) } 670615\end{array}$ \\
\hline 16. & Giacomino, Claudio & $\begin{array}{l}\text { Argentine Embassy } \\
\text { Drammensveien } 39 \\
\text { 0244 Oslo, } \\
\text { NORWAY }\end{array}$ & $\begin{array}{l}\text { Gcx@mrecic.gov.ar } \\
\text { Tel: (47) } 22552448 / 9 \\
\text { Fax: (47) } 22441641\end{array}$ \\
\hline 17. & Obando, German & $\begin{array}{l}\text { Head of the Research and } \\
\text { Development Program } \\
\text { Fundación para el Desarrollo } \\
\text { de la Coordillera Volcánica } \\
\text { Central (FUNDECOR) } \\
\text { Puerto Viejo de Sarapiqui } \\
\text { Apdo Postal 54-3079, } \\
\text { Heredia, COSTA RICA }\end{array}$ & $\begin{array}{l}\text { Gobando@fundecor.or.cr } \\
\text { Tel: (506) } 7666147 \\
\text { Fax: (506) } 7666203\end{array}$ \\
\hline 18. & Vargas, Everton & $\begin{array}{l}\text { Minister } \\
\text { Head of the Division for the } \\
\text { Environment } \\
\text { Ministry of External Relations } \\
\text { Esplanada dos Ministerios } \\
\text { Blonco H Annexo 1 Sala } 635 \\
70170-9 \text { - Brasilia, BRAZIL }\end{array}$ & $\begin{array}{l}\text { Evargas@mre.gov.br } \\
\text { Tel: (55) } 614116985 / 86 \\
\text { Fax: (55) } 613225523\end{array}$ \\
\hline 19. & Venegas, Victor & $\begin{array}{l}\text { Forest Policy Advisor } \\
\text { Ministerio de Agricultura } \\
\text { Teatinos } 40,9^{\circ} \text { piso } \\
\text { Santiago } \\
\text { CHILE }\end{array}$ & 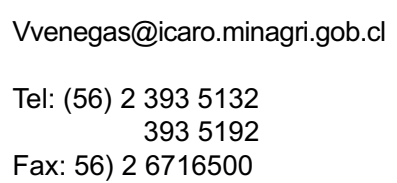 \\
\hline
\end{tabular}




\section{Developed Countries}

\section{Industrialised}

\begin{tabular}{|c|c|c|c|}
\hline No. & Name & Address & E-mail/Tel/Fax \\
\hline 20. & Aalde, Oluf & $\begin{array}{l}\text { Director General of Forestry } \\
\text { Ministry of Agriculture } \\
\text { Forestry Department } \\
\text { P.O. Box } 8007 \text { Dep., } 0030 \text { Oslo, NORWAY }\end{array}$ & $\begin{array}{l}\text { Oluf.aalde@ld.dep.no } \\
\text { Tel: (47) } 22249360 \\
\text { Fax: (47) } 22242754\end{array}$ \\
\hline 21. & Aho, Markku & $\begin{array}{l}\text { Chairman } \\
\text { International Forestry Advisory Group } \\
\text { Ministry of Foreign Affairs } \\
\text { Box } 17600161 \text { Helsinki, FINLAND }\end{array}$ & $\begin{array}{l}\text { Markku.Aho@formin.fi } \\
\text { Tel: (358) } 913416422 \\
\text { Fax: (358) } 913416428\end{array}$ \\
\hline 22. & Ballhorn, Richard & $\begin{array}{l}\text { Director General } \\
\text { International Environmental Affairs } \\
\text { Bureau, Department of Foreign Affairs and } \\
\text { Trade } \\
125 \text { Sussex Drive, Ottawa, ONT } \\
\text { CANADA K1A 0G2 }\end{array}$ & $\begin{array}{l}\text { Richard.ballhorn@dfait- } \\
\text { maeci.gc.ca } \\
\text { Tel: (1) } 6139440886 \\
\text { Fax: (1) } 6139440892\end{array}$ \\
\hline 23. & Bjørnebye, Erik & $\begin{array}{l}\text { Ministry of Foreign Affairs } \\
\text { P.O. Box } 8114 \text { Dep., } \\
\text { 0030 Oslo, } \\
\text { NORWAY }\end{array}$ & $\begin{array}{l}\text { Erik.bjornebye@mfa.no } \\
\text { Tel: (47) } 22243619 \\
\text { Fax: (47) } 22242782\end{array}$ \\
\hline 24. & $\begin{array}{l}\text { Christiansen, } \\
\text { Thure }\end{array}$ & $\begin{array}{l}\text { Head of Section } \\
\text { Secretariat of Environment and } \\
\text { Sustainable Development } \\
\text { Asiatisk Plads } 2 \\
\text { DK-1448 Copenhagen K, DENMARK }\end{array}$ & $\begin{array}{l}\text { Thuchr@um.dk } \\
\text { Tel: (45) } 33920778 \\
\text { Fax: (45) } 33921678\end{array}$ \\
\hline 25. & Davies, Penny & $\begin{array}{l}\text { Senior Forestry Adviser } \\
\text { Department for International Development } \\
\text { (DFID) } \\
94 \text { Victoria St. } \\
\text { London SW1E 5JL, UK }\end{array}$ & $\begin{array}{l}\text { Penny-davies@dfid.gov.uk } \\
\text { Tel: (44) } 2079170313 \\
\text { Fax: (44) } 2079170624\end{array}$ \\
\hline
\end{tabular}

26. Dewdney, Richard Department for International Development (DFID)
94 Victoria St.
London SW1E 5JL, UK
Tel: (44) 1719170077
Fax: (44) 1719170679

R-Dewdney@dfid.gov.uk

27. Falcone, Patrick Bureau de la gestion des resources

Patrick.falcone@diplomatie.gouv.fr naturalles et de l'environment

20, rue Monsieur

Tel: (33) 153693131

75700 Paris, FRANCE

Fax: (33) 153693006 


\begin{tabular}{|c|c|c|c|}
\hline No. & Name & Address & E-mail/Tel/Fax \\
\hline 28. & $\begin{array}{l}\text { Falkenberg, Claus- } \\
\text { Michael }\end{array}$ & $\begin{array}{l}\text { Consultant } \\
\text { GTZ } \\
\text { Schulten Immenbarg } 10 \\
\text { 22587 Hamburg } \\
\text { GERMANY }\end{array}$ & $\begin{array}{l}\text { Claus-Michael.Falkenberg@t- } \\
\text { online.de } \\
\text { Tel: (49) } 408664058 \\
\text { Fax: (49) } 408663115\end{array}$ \\
\hline 29. & Hartvig, BrittMarie & $\begin{array}{l}\text { Special Adviser } \\
\text { Ministry for Foreign Affairs } \\
\text { Gustav Adolfs Torg } 1 \\
10339 \text { Stockholm } \\
\text { SWEDEN }\end{array}$ & $\begin{array}{l}\text { Brittmarie.hartvig@foreign. } \\
\text { ministry.se } \\
\text { Tel: (46) } 84053278 \\
\text { Fax: (46) } 87231176\end{array}$ \\
\hline 30. & Jensen, Olav Bakken & $\begin{array}{l}\text { Adviser } \\
\text { Ministry of the Environment } \\
\text { P.O. Box 8013, Dep., } \\
\text { N-0030 Oslo, NORWAY }\end{array}$ & $\begin{array}{l}\text { Obj@md.dep.no } \\
\text { Tel: (47) } 22245872 \\
\text { Fax: (47) } 22242756\end{array}$ \\
\hline 31. & Jespersen, Claus & $\begin{array}{l}\text { Director of Forest Policy Divison } \\
\text { Danish Ministry of Forest Policy } \\
\text { Division } \\
\text { National Forest and Nature agency } \\
\text { Hasaldsgade } 53 \\
2100 \text { Copenhagen } \varnothing \text {, DENMARK }\end{array}$ & $\begin{array}{l}\text { Cje@sns.dk } \\
\text { Tel: (45) } 39472601 \\
\text { Fax: (45) } 39279899\end{array}$ \\
\hline 32. & Linddal, Michael & $\begin{array}{l}\text { Technical Advisor, PhD } \\
\text { Environment and Natural Resources } \\
\text { Ministry of Foreign Affairs } \\
\text { Asiatisk Plads 2, DK } 1448 \\
\text { Copenhagen K } \\
\text { DENMARK }\end{array}$ & $\begin{array}{l}\text { Miclin@um.dk } \\
\text { Tel: (45) } 33920241 \\
\text { Fax: (45) } 32540533\end{array}$ \\
\hline 33. & McAlpine, Jan & $\begin{array}{l}\text { Senior Foreign Affairs Officer } \\
\text { Forests, Deserts and Drylands } \\
\text { U. S. Department of State } \\
\text { OES/ETC, Room } 4333 \mathrm{MS} \\
\text { Ronald Reagan Building } \\
1300 \text { Pennsylvania Avenue, NW. } \\
\text { Washington DC. 20520, USA }\end{array}$ & $\begin{array}{l}\text { McAlpineJL@state.gov } \\
\text { Tel: (1) } 2026474799 \\
\text { Fax: (1) } 2026475247\end{array}$ \\
\hline 34. & Øistad, Knut & $\begin{array}{l}\text { Deputy Director, Royal Ministry of } \\
\text { Agriculture, Forestry Department } \\
\text { P.O. Box } 8007 \text { Dep., } \\
\text { 0030 Oslo, NORWAY }\end{array}$ & $\begin{array}{l}\text { Knut.oistad@Id.dep.telemax.no } \\
\text { Tel: (47) } 22249362 \\
\text { Mobile: (47) } 90534375 \\
\text { Fax: (47) } 22242754\end{array}$ \\
\hline 35. & Persson, Reidar & $\begin{array}{l}\text { Swedish University of Agricultural } \\
\text { Sciences } \\
\text { Box } 7060 \\
75007 \text { Uppsala, SWEDEN }\end{array}$ & $\begin{array}{l}\text { Reidar.persson@sh.slu.se } \\
\text { Tel: (46) } 18673842 \\
\text { Fax: (46) } 18673800\end{array}$ \\
\hline
\end{tabular}




\begin{tabular}{|c|c|c|c|}
\hline No. & Name & Address & E-mail/Tel/Fax \\
\hline 36. & Roberts, Ralph & $\begin{array}{l}\text { Chief Forester } \\
\text { CIDA-Canadian International } \\
\text { Development Agency } \\
\text { 200, Promenade du Portage } \\
\text { Hull (Quebec), K1A 0G4, } \\
\text { CANADA }\end{array}$ & $\begin{array}{l}\text { RALPH_ROBERTS@acdi- } \\
\text { cida.gc.ca } \\
\text { Tel: (1) } 8199976586 \\
\text { Fax: (1) } 8199533348\end{array}$ \\
\hline 37. & Skåre, Siri & $\begin{array}{l}\text { Adviser, Technical Department } \\
\text { Norwegian Agency for Development } \\
\text { Co-operation (NORAD) } \\
\text { Ruseløkvn 26, PB } 8034 \text { Dep. } \\
\text { N-0030 Oslo, NORWAY }\end{array}$ & $\begin{array}{l}\text { Siri.skare@norad.no } \\
\text { Tel: (47) } 22240207 \\
\text { Fax: (47) } 22240276\end{array}$ \\
\hline 38. & Sommer, Adrian & $\begin{array}{l}\text { Senior Forest Advisor } \\
\text { Swiss Development Co-operation } \\
\text { (SDC), Section Environment, } \\
\text { Forests, Energy } \\
\text { Freiburgstrasse 130, CH-3003 Bern } \\
\text { SWITZERLAND }\end{array}$ & $\begin{array}{l}\text { Adrian.Sommer@deza.admin.ch } \\
\text { Tel: (41) } 313259307 \\
\text { Fax: (41) } 313259362\end{array}$ \\
\hline 39. & Thomas, Peter & $\begin{array}{l}\text { Minister-Counsellor (Agriculture) } \\
\text { Australian Embassy \& Mission to the EU } \\
\text { Rue Guimard } 6 \\
1180 \text { Brussels, } \\
\text { BELGIUM }\end{array}$ & $\begin{array}{l}\text { Peter.Thomas@dfat.gov.au } \\
\text { Tel: (32) } 22860513 / 532 \\
\text { Fax: (32) } 22306802\end{array}$ \\
\hline
\end{tabular}

\section{Countries in Transition}

No. Name

40. Petrov, Anatoly

\section{Address}

Rector, Professor

Russian Institute of Continous

Education in Forestry

Instituskaya Street

17 Puskino Town

Moscow Region 141200, RUSSIA

\section{E-mail/Tel/Fax}

Vipklh.mail@mtu-net.ru

Tel: (7) 0959933644

Fax: (7) 0965328909 


\section{Private Sector}

\begin{tabular}{|c|c|c|c|}
\hline No. & Name & Address & E-mail/Tel/Fax \\
\hline 41. & Brand, David & $\begin{array}{l}\text { Director, Carbon Programs } \\
\text { Hancock Natural Resource Group } \\
21 \text { Hillgate Place } \\
\text { Castle Hill 2154, AUSTRALIA }\end{array}$ & $\begin{array}{l}\text { Dbrand@hnrg.com.au } \\
\text { Tel: (61) } 288505890 \\
\text { Fax: (61) } 288505891\end{array}$ \\
\hline 42. & Mertz, Peter & $\begin{array}{l}\text { Managing Director } \\
\text { UBS Asset Management } \\
\text { UBS Brinson Inc. } \\
\text { Trade Center, } 4^{\text {th }} \text { Floor, } 24 \text { Airport } \\
\text { Road } \\
\text { West Lebanon, NH 03784, USA }\end{array}$ & $\begin{array}{l}\text { Peter.mertz@ubs.com } \\
\text { Tel: (1) } 6032987001 \\
\text { Fax: (1) } 6032987620\end{array}$ \\
\hline
\end{tabular}

\section{NGOs}

\begin{tabular}{|c|c|c|c|}
\hline No. & Name & Address & E-mail/Tel/Fax \\
\hline 43. & Hufnagl, Natalié & $\begin{array}{l}\text { Secretary General } \\
\text { Confederation of European Forest } \\
\text { Owners } \\
\text { Rue du Luxembourg } 47-51 \\
\text { B-1050 Brussels, BELGIUM }\end{array}$ & $\begin{array}{l}\text { Cepf@planetinternet.be } \\
\text { Tel: (32) } 22190231 \\
\text { Fax: (32) } 22192191\end{array}$ \\
\hline 44. & Landell-Mills, Natasha & $\begin{array}{l}\text { Research Associate } \\
\text { International Institute for } \\
\text { Environment and Development } \\
3 \text { Endsleigh St., London WC1H } \\
\text { ODD, UK }\end{array}$ & $\begin{array}{l}\text { Natasha.landell-mills@iied.org } \\
\text { Tel: (44) } 2073882117 \\
\text { Fax: (44) } 2073882826\end{array}$ \\
\hline 45. & Muthoo, Maharaj & $\begin{array}{l}\text { Executive Director } \\
\text { Forest Stewardship Council (FSC) } \\
\text { Av. Hidalgo } 502 \\
68000 \text { Oaxaca, } \\
\text { MEXICO }\end{array}$ & $\begin{array}{l}\text { Mmuthoo@hotmail.com } \\
\text { Mmuthoo@fscoax.org } \\
\\
\text { Tel: +52 } 95146905 \\
\text { Fax: (52) } 95162110\end{array}$ \\
\hline 46. & Rodriguez, Manuel & $\begin{array}{l}\text { Carrera } 10 \text { No. } 86-89 \\
\text { Bogota } \\
\text { COLOMBIA }\end{array}$ & $\begin{array}{l}\text { Mcrod@cable.net.co } \\
\text { Tel: (571) } 6100136 / 6108576 \\
\text { Fax: (571) } 5304772\end{array}$ \\
\hline
\end{tabular}




\section{Multilateral and Other International Organisations}

\begin{tabular}{|c|c|c|c|}
\hline No. & Name & Address & E-mail/Tel/Fax \\
\hline 47. & Bazill, John & $\begin{array}{l}\text { Tropical Forests Expert } \\
\text { DG Development } \\
\text { European Commission, } \\
\text { Office: G12 5/31 } \\
\text { Rue de la Loi, Wetstraat } 200 \\
\text { B-1049 Brussel, BELGIUM }\end{array}$ & $\begin{array}{l}\text { John.Bazill@cec.eu.int } \\
\text { Tel: (32) } 22999 \text { 842, } 2991111 \\
\text { Fax: (32) } 22990961\end{array}$ \\
\hline 48. & Brooks, David & $\begin{array}{l}\text { Research Forester, USDA Forest } \\
\text { Service } \\
\text { Pacific Northwest Research Station } \\
\text { Corvallis Forestry Sciences Lab } \\
3200 \text { SW Jefferson Way, } \\
\text { Corvallis, OR 97331, USA }\end{array}$ & $\begin{array}{l}\text { Dbrooks01@fs.fed.us } \\
\text { Tel: (1) } 5417507416 \\
\text { Fax: (1) } 5417507329 \\
\text { Mobile: } 5416024471\end{array}$ \\
\hline 49. & Douglas, James & $\begin{array}{l}\text { Forest Advisor } \\
\text { World Bank } \\
1818 \text { H St. NW } \\
\text { Washington D.C. 20034, USA }\end{array}$ & $\begin{array}{l}\text { Jdouglas@worldbank.org } \\
\text { Tel: (1) } 2024582273 \\
\text { Fax: (1) } 2025221152\end{array}$ \\
\hline 50. & Keipi, Kari & $\begin{array}{l}\text { Espcialista Senior en } \\
\text { Recursos Naturales } \\
\text { División de Medio Ambiente } \\
\text { Banco Interamericano de Desarrollo } \\
1300 \text { New York Avenue, N.W. } \\
\text { Washington, D.C. } 20577, \text { USA }\end{array}$ & $\begin{array}{l}\text { Karik@iadb.org } \\
\text { Tel: (1) } 2026231939 \\
\text { Fax: (1) } 2026231786\end{array}$ \\
\hline 51. & Kufakwandi, Frank S. & $\begin{array}{l}\text { Senior Forestry Specialist } \\
\text { African Development Bank } \\
\text { B.P.V. } 316 \text { Abidjan } \\
\text { IVORY COAST }\end{array}$ & $\begin{array}{l}\text { S.kufakwandi@afdb.org } \\
\text { Tel: (225) } 205486 \\
\text { Fax: (225) } 204099\end{array}$ \\
\hline 52. & Kumari, Kanta & $\begin{array}{l}\text { Biodiversity Program Manager } \\
\text { Global Environment Facility (GEF) } \\
1818 \text { H Street, N.W. } \\
\text { Washington, DC } 20433 \text {, USA }\end{array}$ & $\begin{array}{l}\text { Kkumari@worldbank.org } \\
\text { Tel: (1) } 2024734269 \\
\text { Fax: (1) } 2025223240\end{array}$ \\
\hline 53. & Ljungman, Lennart & $\begin{array}{l}\text { Director } \\
\text { Forestry Policy and Planning Division } \\
\text { Food and Agriculture Organization } \\
\text { of the UN } \\
\text { FAO Forestry Department, } \\
\text { Room D-442 } \\
\text { Viale delle Terme di Caracalla } \\
00100 \text { Rome, ITALY }\end{array}$ & $\begin{array}{l}\text { Lennart.Ljungman@fao.org } \\
\text { Tel: (39) } 0657055205 \\
\text { Fax: (39) } 0657055137\end{array}$ \\
\hline 54. & Maini, Jag & $\begin{array}{l}\text { Coordinator and Head } \\
\text { UNFF Secretariat } \\
\text { Two UN Plaza, DC2-1270 } \\
\text { New York, NY 10017, USA }\end{array}$ & $\begin{array}{l}\text { Maini@un.org } \\
\text { Tel: (1) } 2129633160 \\
\text { Fax: (1) } 212963-3463\end{array}$ \\
\hline
\end{tabular}




\begin{tabular}{|c|c|c|c|}
\hline No. & Name & Address & E-mail/Tel/Fax \\
\hline 55. & Mersmann, Christian & $\begin{array}{l}\text { Interim Management } \\
\text { UNDP Programme on } \\
\text { Forests (PROFOR) } \\
\text { Sustainable Energy and } \\
\text { Environment Division } \\
304 \text { East } 45^{\text {th }} \text { Street, } 10^{\text {th }} \text { Floor } \\
\text { New York, NY } 10017, \text { USA }\end{array}$ & $\begin{array}{l}\text { Christian.Mersmann@undp.org } \\
\text { Tel: (1) } 2129065822 \\
\text { Fax: (1) } 2129066973\end{array}$ \\
\hline 56. & Ryden, Per Axel & $\begin{array}{l}\text { Managing Director } \\
\text { Global Mechanism } \\
\text { of the UNCCD } \\
\text { C/o International Fund for } \\
\text { Agricultural Development } \\
\text { Via del Serafico, } 107 \\
00142 \text { Rome, ITALY }\end{array}$ & $\begin{array}{l}\text { P.ryden@ifad.org } \\
\text { Tel: (39) } 0654592146 \\
\text { Fax: (39) } 0654592135\end{array}$ \\
\hline
\end{tabular}

\section{Resource Persons}

\begin{tabular}{|c|c|c|c|}
\hline No. & Name & Address & E-mail/Tel/Fax \\
\hline 57. & Chan, Barney & $\begin{array}{l}\text { General Manager } \\
\text { Sarawak Timber Association } \\
10^{\text {th }} \text { Floor, Wisma Sumber Alam, } \\
\text { Kuching } \\
\text { P.O. Box } 171 \text { Bukit Permata Kuching } \\
93100 \text { Kuching } \\
\text { Sarawak, MALAYSIA }\end{array}$ & $\begin{array}{l}\text { Belachan@aol.com } \\
\text { Sta@sta.org.my } \\
\text { Tel: (60) } 82442935 \\
\text { Fax: (60) } 82441477 / 442408\end{array}$ \\
\hline 58. & Chipeta, Mafa & $\begin{array}{l}\text { Deputy Director General } \\
\text { Center for International Forestry } \\
\text { Research (CIFOR) } \\
\text { P.O. Box } 6596 \text { JKPWB } \\
\text { Jakarta 10065, INDONESIA }\end{array}$ & $\begin{array}{l}\text { M.chipeta@cgiar.org } \\
\text { Tel: (62) } 251622622 \\
\text { Fax: (62) } 251622100\end{array}$ \\
\hline 59. & Ganguli , Barin & $\begin{array}{l}\text { President } \\
\text { Foundation For Forestry \& Rural } \\
\text { Development } \\
\text { I-1783, Chittaranjan Park } \\
\text { New Delhi - } 110019 \text {, INDIA }\end{array}$ & $\begin{array}{l}\text { Barin@mail2.bol.net.in } \\
\text { Tel: (91) } 116489775 \\
\text { Fax: (91) } 116489776\end{array}$ \\
\hline
\end{tabular}




\begin{tabular}{|c|c|c|c|}
\hline No. & Name & Address & E-mail/Tel/Fax \\
\hline 60. & Gregersen, Hans & $\begin{array}{l}\text { Prof. Emeritus - University of } \\
\text { Minnesota } \\
2090 \text { E. Tumble Brook Way } \\
\text { Tucson, AZ 85737, USA }\end{array}$ & $\begin{array}{l}\text { Hgregers@forestry.umn.edu } \\
\text { Tel: (1) } 5208257723 \\
\text { Cell phone: (1) } 5208189270 \\
\text { Fax: (1) } 5208189270\end{array}$ \\
\hline 61. & Joshi, Mahendra & $\begin{array}{l}\text { Forestry Advisor } \\
\text { UNFF Secretariat } \\
\text { Two UN Plaza, DC2-1268 } \\
\text { New York, NY 10017, USA }\end{array}$ & $\begin{array}{l}\text { Joshi@un.org } \\
\text { Tel: (1) } 2129631972 \\
\text { Fax: (1) } 2129633463\end{array}$ \\
\hline 62. & Landrot, Jean-Jacques & $\begin{array}{l}\text { Secretary General } \\
\text { Interafrican Forest Industries } \\
\text { Association } \\
\text { 6, Ave. St-Mandé F-75012 } \\
\text { Paris, FRANCE }\end{array}$ & $\begin{array}{l}\text { Ifia@wanadoo.fr } \\
\text { Tel: (33) } 143424200 \\
\text { Fax: (33) } 143425522\end{array}$ \\
\hline 63. & Moura Costa, Pedro & $\begin{array}{l}\text { Managing Director } \\
\text { EcoSecurities Ltd } \\
\text { Delawar House } \\
\text { 45 Raleigh Park Road } \\
\text { Oxford OX2 9AZ, UK }\end{array}$ & $\begin{array}{l}\text { Pedro@ecosecurities.com } \\
\text { Tel: (44) } 1865202635 \\
\text { Fax: (44) } 1865251438\end{array}$ \\
\hline 64. & Schmidt, Ralph & $\begin{array}{l}\text { Arlington Associates } \\
1370 \text { Avenue of the Americas, } \\
\text { Suites } 3300 \\
\text { New York, NY 10019, USA }\end{array}$ & $\begin{array}{l}\text { Arlingtonny@aol.com } \\
\text { Tel: (1) } 2129065088 \\
\text { Fax: (1) } 2129066973\end{array}$ \\
\hline 65. & Scothorne, Richard & $\begin{array}{l}\text { Partners in Economic } \\
\text { Development } \\
71 \text { Murrayfield Gardens } \\
\text { Edinburgh EH } 126 \mathrm{DL} \text {, UK }\end{array}$ & $\begin{array}{l}\text { Partnersed@sol.co.uk } \\
\text { Tel: (44) } 1313375695 \\
\text { Fax: (44) } 1313375021\end{array}$ \\
\hline 66. & Simula, Markku & $\begin{array}{l}\text { Indufor Oy } \\
\text { Töölönkatu } 15 \text { E } \\
\text { Helsinki, FIN-00100, FINLAND }\end{array}$ & $\begin{array}{l}\text { Markku.simula@indufor.fi } \\
\text { Tel: (358) } 96840110 \\
\text { Fax: (358) } 91352552\end{array}$ \\
\hline
\end{tabular}




\section{Support Team}

\begin{tabular}{|c|c|c|c|}
\hline No. & Name & Address & E-mail/Tel/Fax \\
\hline 67. & Ivers, Laura & $\begin{array}{l}\text { Writer/Editor } \\
\text { IISD - Earth Negotiations } \\
\text { Bulletin } \\
212 \text { E. } 47^{\text {th }} \text { St. Apt. 1b } \\
\text { New York NY 11217, USA }\end{array}$ & $\begin{array}{l}\text { Laurai@iisd.org } \\
\text { Tel: (1) } 7182464246 \\
\text { Fax: (1) } 2126440206\end{array}$ \\
\hline 68. & Jackson, Wendy & $\begin{array}{l}\text { Writer/Editor } \\
\text { IISD - Earth Negotiations } \\
\text { Bulletin } \\
212 \text { E. } 47^{\text {th }} \text { St. Apt. 1b } \\
\text { New York NY 11217, USA }\end{array}$ & $\begin{array}{l}\text { Wendy@iisd.org } \\
\text { Tel: (1) } 2126440204 \\
\text { Fax: (1) } 2126440206\end{array}$ \\
\hline 69. & Kustiyawati, Ketty & $\begin{array}{l}\text { Center for International Forestry } \\
\text { Research } \\
\text { P.O. Box } 6596 \text { JKPWB } \\
\text { Jakarta 10065, INDONESIA }\end{array}$ & $\begin{array}{l}\text { K.kustiyawati@cgiar.org } \\
\text { Tel: (62) } 251622622 \\
\text { Fax: (62) } 251622100\end{array}$ \\
\hline 70. & Molteberg, Tore & $\begin{array}{l}\text { Information Consultant } \\
\text { The Norwegian Forestry Society } \\
\text { Wergelandsveien 23B } \\
0167 \text { Oslo, NORWAY }\end{array}$ & $\begin{array}{l}\text { Tore@skogselskapet.no } \\
\text { Tel: (47) } 23365858 \\
\text { Fax: (47) } 22604189\end{array}$ \\
\hline
\end{tabular}




\section{Photo Credits}

Cover by

Carol J.P. Colfer, Christian Cossalter, Herwasono Soedjito

xiii, 35, 69, Christian Cossalter

Page 2, 4, 12, 14, 33, Carol J. P. Colfer

Page 3, Kuswata Kartawinata

Page 5, 25, Takeshi Toma

Page 8, Philippe Guizol

Page 9, Yani Saloh

Page 20, Irdez Azhar

Page 21, 22, 24, Andy Gillison

Page 34, Eva Wollenberg 

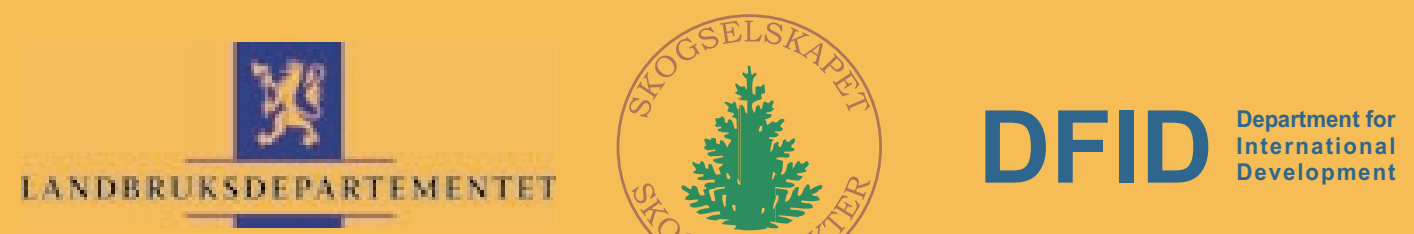

ISBN 979-8764-68-4 